\title{
Directing a messenger RNA into yeast mitochondria
}

\author{
by
}

\author{
Noor Sunba
}

A thesis submitted to the Faculty of Graduate Studies and Research in partial fulfillment of the requirements for the degree of a Master of Science

Department of Biology

Carleton University

Ottawa, Ontario

Canada

2010

Copyright $\mathbb{C}$ Noor Sunba, 2010 


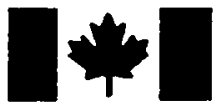

Library and Archives

Canada

Published Heritage

Branch

395 Wellington Street

Ottawa ON K1A ON4

Canada
Bibliotheqque et

Archives Canada

Direction du

Patrimoine de l'édition

395 , rue Wellington

Ottawa ON K1A ON4

Canada
Your file Votre référence

ISBN: 978-0-494-79584-2

Our file Notre reférence

ISBN: 978-0-494-79584-2
NOTICE:

The author has granted a nonexclusive license allowing Library and Archives Canada to reproduce, publish, archive, preserve, conserve, communicate to the public by telecommunication or on the Internet, loan, distribute and sell theses worldwide, for commercial or noncommercial purposes, in microform, paper, electronic and/or any other formats.

The author retains copyright ownership and moral rights in this thesis. Neither the thesis nor substantial extracts from it may be printed or otherwise reproduced without the author's permission.
AVIS:

L'auteur a accordé une licence non exclusive permettant à la Bibliothèque et Archives Canada de reproduire, publier, archiver, sauvegarder, conserver, transmettre au public par télécommunication ou par l'Internet, prêter, distribuer et vendre des thèses partout dans le monde, à des fins commerciales ou autres, sur support microforme, papier, électronique et/ou autres formats.

L'auteur conserve la propriété du droit d'auteur et des droits moraux qui protège cette thèse. $\mathrm{Ni}$ la thèse ni des extraits substantiels de celle-ci ne doivent être imprimés ou autrement reproduits sans son autorisation.
In compliance with the Canadian Privacy Act some supporting forms may have been removed from this thesis.

While these forms may be included in the document page count, their removal does not represent any loss of content from the thesis.
Conformément à la loi canadienne sur la protection de la vie privée, quelques formulaires secondaires ont été enlevés de cette thèse.

Bien que ces formulaires aient inclus dans la pagination, il n'y aura aucun contenu manquant.

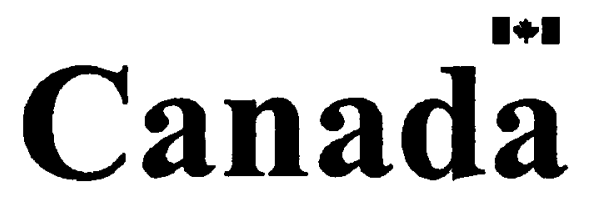




\begin{abstract}
$\underline{\text { ABSTRACT }}$
Mitochondria are complex eukaryotic organelles that are involved in numerous cellular tasks, most notably energy production and apoptosis. A malfunction in any of these tasks can result in a broad range of complications. Mitochondrial DNA mutations, whether inherited or acquired, cause impaired respiratory chain functioning. This, in turn, leads to decreased production of energy and formation of free radicals, which result in a series of phenotypic expressions, otherwise known as mitochondrial disorders.
\end{abstract}

There are many diseases associated with non-functional mitochondrial genes. Therefore, targeting mRNAs that mediate the synthesis of a functional copy of the protein into mitochondria can be used for therapeutic purposes. As an initial step, here we investigate the import of mRNAs into the mitochondria of budding yeast, Saccharomyces cerevisiae, using a lacZ mRNA reporter construct.

The untranslated 3' and 5' regions of mRNAs are thought to play a key role in directing and regulating the activity of a mRNA. Here, we hypothesized that a 3' untranslated region of OXA1 mRNA may direct mRNAs into mitochondria. This region has been previously shown to direct different mRNAs into the vicinity of mitochondria. We also used a mitochondria-specific translation signal at the 5' untranslated region of $C O X 2$ mRNA to investigate presence and functionality in mitochondria.

We successfully designed the constructs and transformed them into $S$ cerevisiae. In addition, we performed further extensive experimental analysis to examine the activity of our designed mRNAs in yeast. 


\section{ACKNKOWLEGMENTS}

First of all, I would like to thank my supervisor Dr. Ashkan Golshani for being a true mentor throughout this journey. Your constant support, guidance and patience proved essential to my completion of this amazing project. I have known you since you first came to Carleton University. I am very proud to have been your student for all these years. You made me the scientist that I am today and so I am forever indebted to you. Thank you very much.

I would also like to thank my family doctor, Dr. Neda Amani-Golshani, for being the cool and amazing doctor she is. You saved my life and helped me get through the toughest times. I can not thank you enough. I wish that God continues to give you the strength, happiness and success that you need to go on and make a difference in people's lives. I love you lots.

Next, to my awesome lab mates, especially, Mathew Jessulat, Md. Alamgir, Nazila Nazemof, and Mohsen Hooshyar, you truly made my time in the lab a memorable one. I do not know how I could have gotten through working in the lab without you. Thank you for always helping me out whenever I needed the help. You are wicked scientists. I learned a lot from you. I wish you all the luck and success in the next chapter of your lives.

To Dr. Willmore, Dr. Aitken, Dr. Lambert and Sue Patterson as well as my neighbor lab mates on the molecular floor, thank you for saving the day when it was almost a complete disaster. Thanks for everything you taught me. I enjoyed learning from you.

Thanks to all the staff at the Biology Department of Carleton University. Your hard work is greatly appreciated. Thank you for always supporting your students.

Finally, to my family and friends thank you for always being there for me and supporting me throughout my schooling. My life would be nothing without you. I dedicate this work to you. I love you very much. 


\section{TABLE OF CONTENTS}

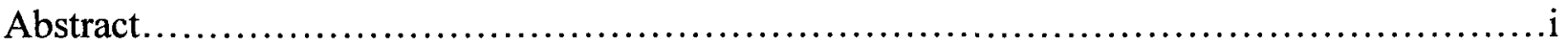

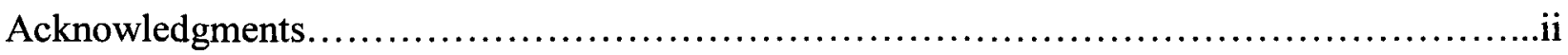

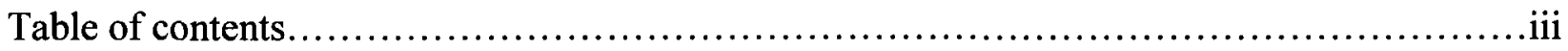

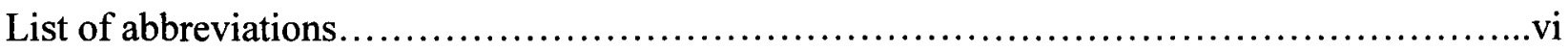

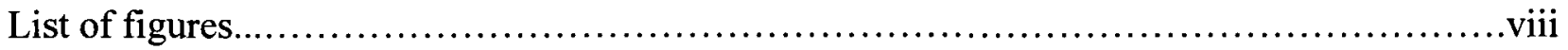

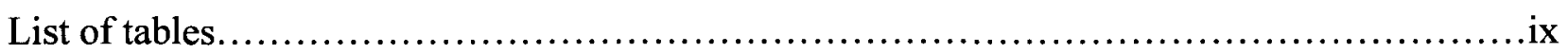

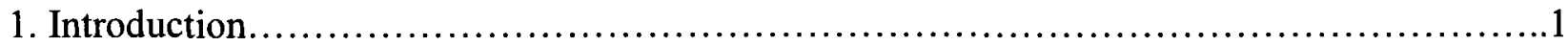

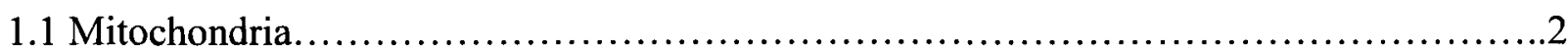

1.1.1 Mitochondria Genetics...................................................

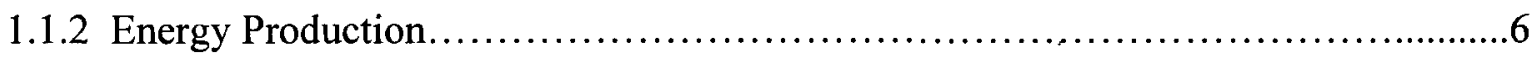

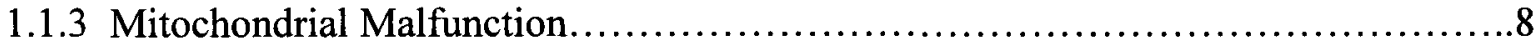

1.1.4 Mitochondrial Diseases........................................................

1.2 Yeast as a Model Organism..................................................... 14

1.2.1 Translation and Mitochondria.................................................16

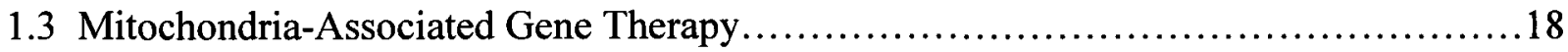

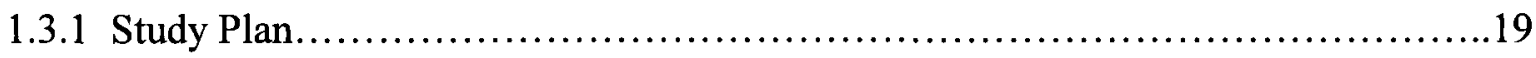

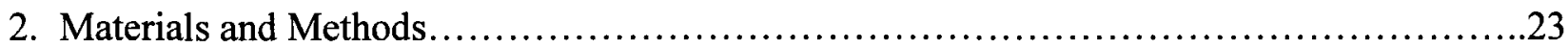

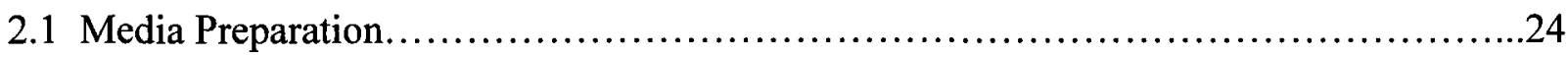

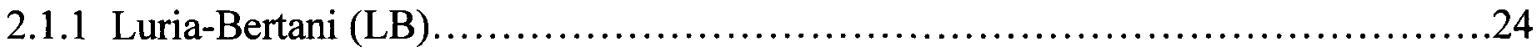

2.1.2 Yeast Extract Peptone Dextrose (YPD) ....................................24

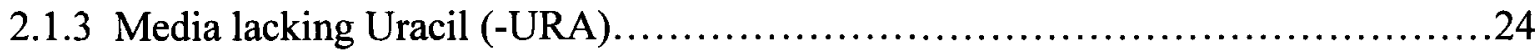

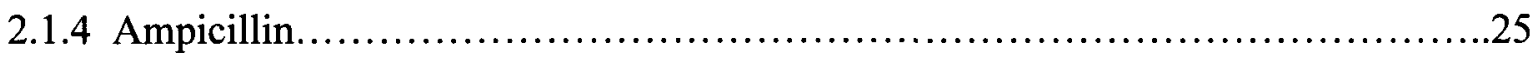




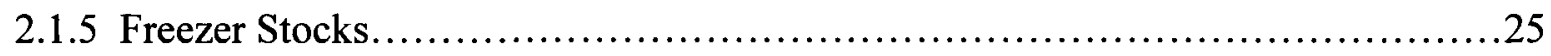

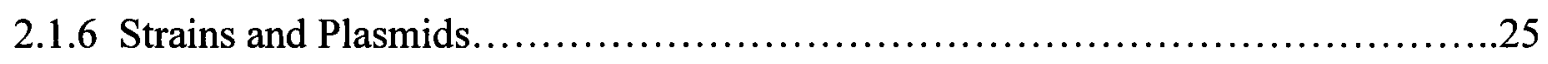

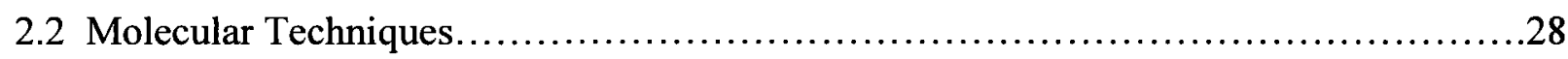

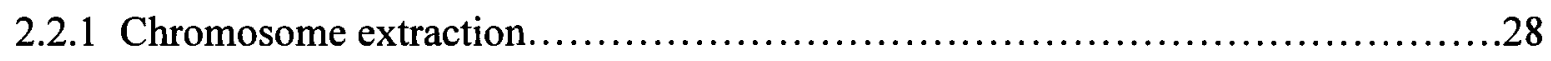

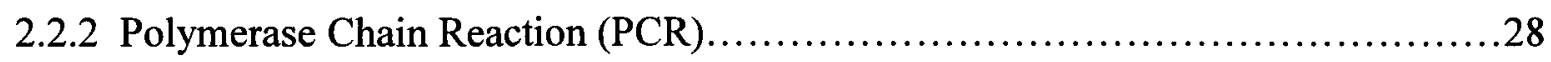

2.2.3 Phenol-Chloroform Extraction of Mt RNA ................................... 31

2.2.4 Reverse Transcriptase Polymerase Chain Reaction (RT-PCR) ..................32

2.2.5 Agarose gel electrophoresis............................................. 33

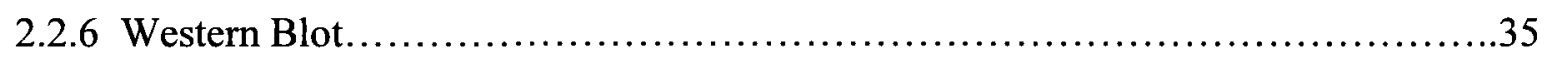

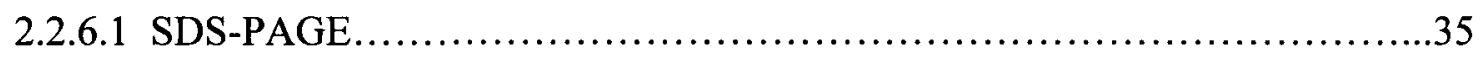

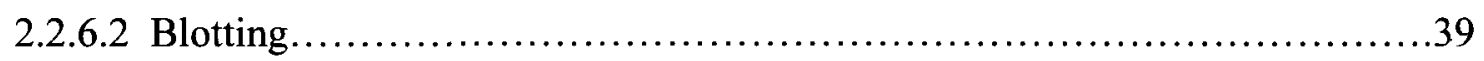

2.2.6.3 Blocking and Washings............................................. 39

2.2.6.4 Visualization............................................................ 40

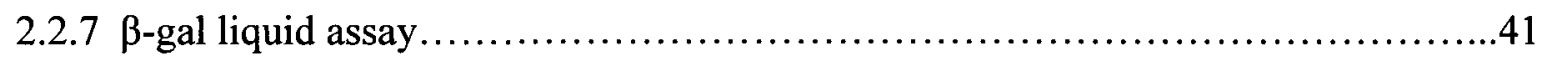

2.2.8 Mitochondria Isolation.......................................................

2.2.9 Restriction Digest.............................................................

2.2.10 Plasmid Extraction.............................................................

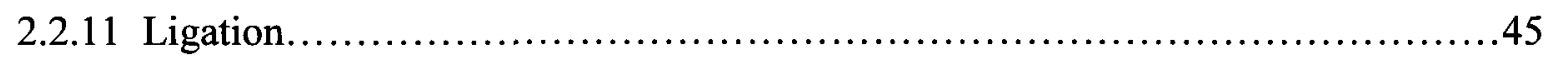

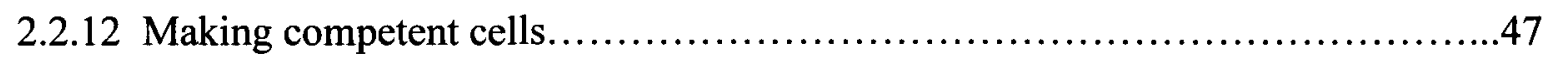

$2.2 .13 E$ coli Transformation.................................................... 47

2.2.14 Yeast transformation....................................................... 48

2.3 Construction of plasmids containing target mRNAs..............................48 


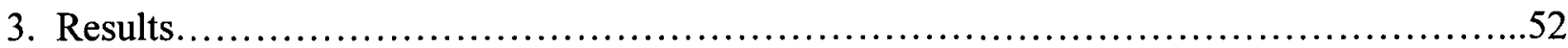

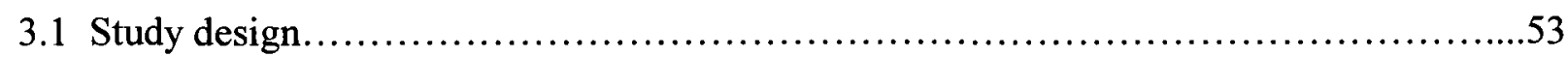

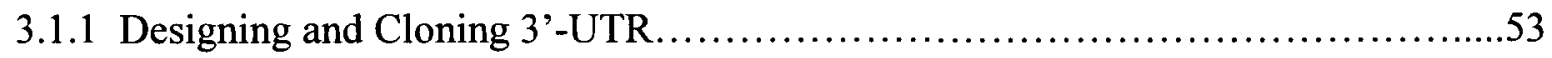

3.1.2 Designing and Cloning 5 '-UTR ...........................................60

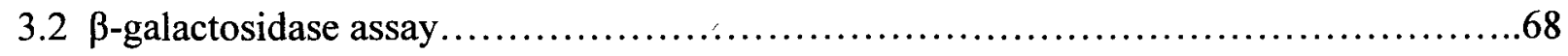

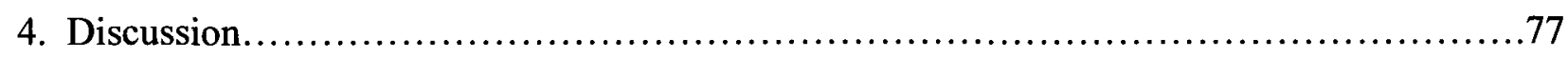

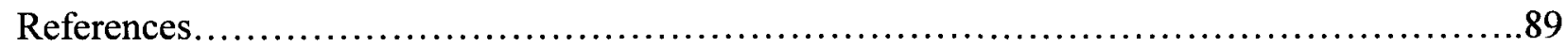




\section{LIST OF ABBREVIATIONS}

Ach

ADP

ATP

AD

Amp

bp

cDNA

DNA

DA

ETC

$\mathrm{EtOH}$

$\mathrm{EtBr}$

FFE

$\mathrm{H}_{2} \mathrm{O}_{2}$

$\mathrm{kb}$

LiOAc

LB

M.P

mRNA

$\mu \mathrm{m}$

MQ $\mathrm{H}_{2} \mathrm{O}$

$\mathrm{mt}$
Acetylcholine

Adenosine diphosphate

Adenosine triphosphate

Alzheimer's disease

Ampicillin

Base Pair

Complimentary Deoxyribonucleic acid

Deoxyribonucleic acid

Dopamine

Electron Transport Chain

Ethanol

Ethidium bromide

Free Flow Electrophoresis

Hydrogen Peroxide

Kilobases or Kilobase pairs

Lithium acetate

Luria-Bertani

Master Plate

Messenger RNA

Micrometer

Milli-Q water (Ultra pure water)

Mitochondria 


\begin{tabular}{|c|c|}
\hline mtDNA & Mitochondrial DNA \\
\hline mitoribosome & Mitochondrial ribosome \\
\hline NA & Noradrenaline \\
\hline nDNA & Nuclear DNA \\
\hline OXPHOS & Oxidative Phosphorylation \\
\hline PD & Parkinson's Disease \\
\hline PCR & Polymerase Chain Reaction \\
\hline ROS & Reactive Oxygen Species \\
\hline RPM & Revolutions per Minute \\
\hline RNA & Ribonucleic acid \\
\hline rRNA & Ribosomal RNA \\
\hline SGD & Saccharomyces Genome Database \\
\hline 5-HT & Serotonin \\
\hline ssON & Single-stranded oligonucleotide \\
\hline SDS-PAGE & Sodium dodecyle sulfate-Polyacrylamide Gel Electrophoresis \\
\hline SN & Substantia Nigra \\
\hline $\mathrm{O}_{2}$ & Superoxide \\
\hline SOD & Superoxide Dismutase \\
\hline SGA & Synthetic Genetic Array \\
\hline tRNA & Transfer RNA \\
\hline YPD & Yeast Extract Peptone Dextrose \\
\hline
\end{tabular}




\section{$\underline{\text { LIST OF FIGURES }}$}

Figure

Page

Figure 1.1

The Mitochondrion 3

Figure 1.2

Maps of yeast and human mtDNAs .5

Figure 1.3

Mitochondrial electron transport chain showing

the four complexes and cytochrome $c$.

Figure 1.4

Mitochondrial alterations associated with $\mathrm{PD}$

Figure 2.1

Plasmid map of p416 GALL

Figure 3.1

Constructed vector $\mathrm{p} 416$ showing the inserted

3'-UTR and lacZ.

Figure 3.2

Agarose gel of recombinant $\mathrm{p} 416$ containing

3'-UTR digested with BamHI.

Figure 3.3

Agarose gel of recombinant p416 containing 3'-UTR

digested with ClaI

Figure 3.4

The designed constructs.

Figure 3.5

Agarose gel of recombinant $\mathrm{p} 416$ containing

3'- and 5'-UTR digested with XbaI.

Figure 3.6

Agarose gel of recombinant $\mathrm{p} 416$ containing

3'- and 5'-UTR digested with $B g l I$.

Figure 3.7

Average $\beta$-galactosidase activity for isolated yeast $\mathrm{mt}$.

Figure 3.8

Figure 3.9

Western blot of 3 isolated mitochondria samples from yeast, each carrying a different construct.

RT-PCR of RNA isolated from mitochondria.

Figure 3.10

Profile of isolated mitochondria after zone electrophoresis fractionation using BD Free Flow Electrophoresis (FFE) system

Figure 3.11

Purification of isolated mitochondria, containing 3' and 5' construct, using BD Free Flow Electrophoresis system. 


\section{$\underline{\text { LIST OF TABLES }}$}

Table

Page

Table 2.1

Strains and plasmids used in this study .26

Table 2.2

Sequences for 3' primers used in PCR ...............................30

Table 2.3

General volumes used in agarose gel electrophoresis 34

Table 2.4

Recipe for making an $8 \%$ resolving gel for SDS-PAGE. 36

Table 2.5

Recipe for making a stacking gel for SDS-PAGE .37

Table 2.6

Example of a restriction digestion. .44

Table 2.7

Example of a ligation trial. .46

Table 2.8

Sequence for single-stranded 5' primer. .50

Table 3.1

Sequence of yeast $O X A 1$ 3'-UTR (158bp) .56

Table 3.2

Sequences used in the designed constructs .61 


\section{1: Introduction}




\section{CHAPTER 1: INTRODUCTION}

\subsection{Mitochondria}

Mitochondria (mt) are found in most eukaryotic cells. They are referred to as the "powerhouse" of the cell because of their primary function to convert organic matter into energy via the process of oxidative phosphorylation (OXPHOS) (Lu, 2009). They generally have their own genome and gene expression machinery, and can occupy up to $25 \%$ of the cell's cytoplasm (Figure 1.1[a]). They are usually a few micrometers $(\mu \mathrm{m})$ long and up to one $\mu \mathrm{m}$ wide (Becker et al., 2003). The mt has two membranes; an outer membrane and an inner membrane that are separated by an intermembrane space. The inner membrane is folded up to form compartments referred to as cristae. The internal semi-fluid mt space is called the matrix (Figure 1.1[b],[c]) (Fox, 2009).

The generally accepted model of mt origin is the endosymbiotic theory. This theory claims that eukaryotic cells have evolved from prokaryotic ones, and that $\mathrm{mt}$ are the direct descendants of bacterial endosymbionts (Margulis, 1976). These efficient, energy-converting organelles are highly conserved through the course of evolution and have a number of prokaryotic-like characteristics. Therefore, studying biological pathways of simple prokaryotes and eukaryotes may shed some light on important mt pathways in higher eukaryotes such as humans (Gray et al., 1999).

Mt play a central role in many cellular functions, including bioenergetics, apoptosis, and the metabolism of amino acids, lipids, and iron (Sickmann et al., 2003). In the next sections some important properties of mt will be discussed. 


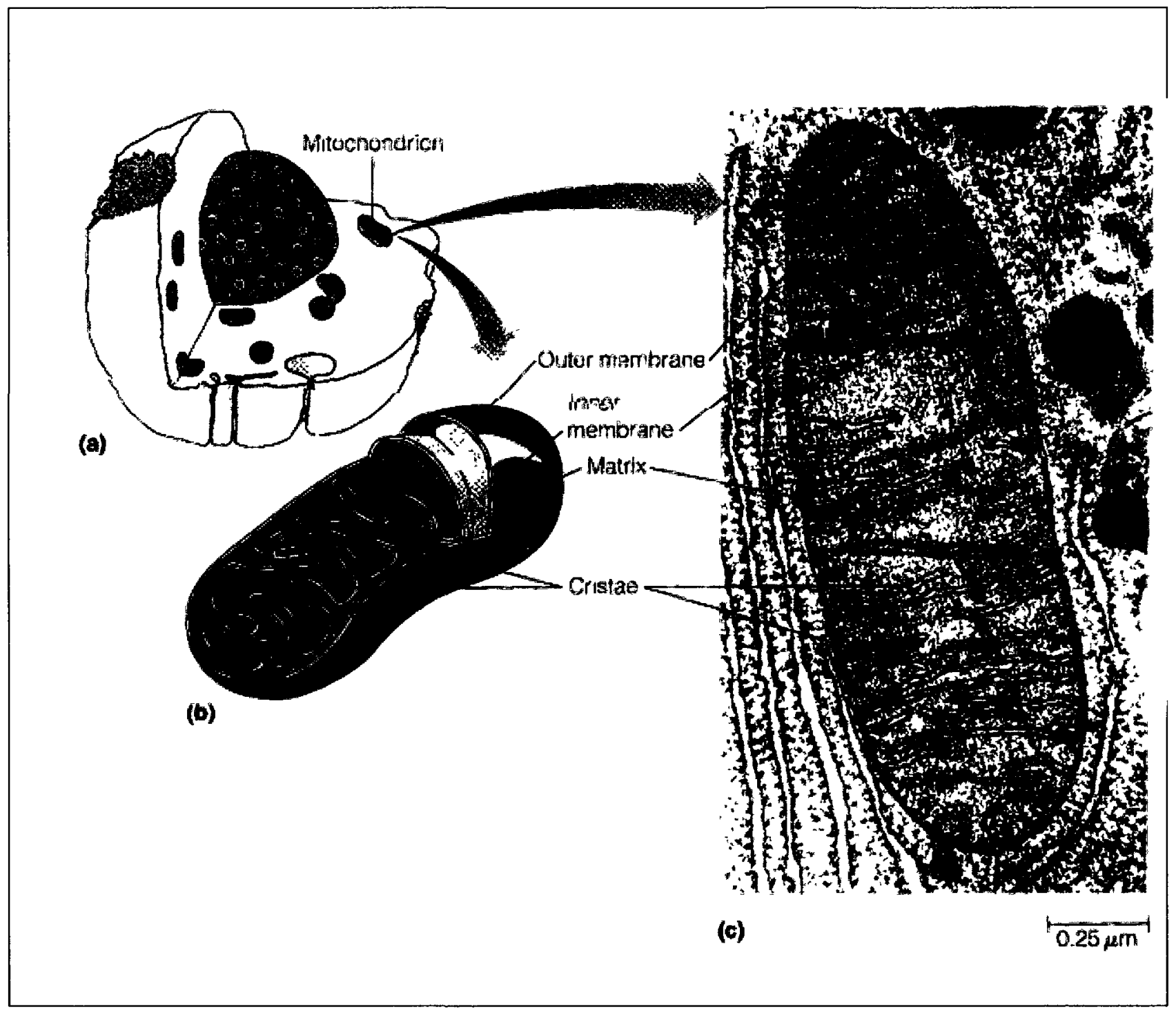

Figure 1.1: The Mitochondrion. (a) A cross-section view showing the relative numbers and size of the mt within an animal cell. (b) A schematic illustration of mt structure showing its outer and inner membranes, matrix and cristae. (c) An electron micrograph of a mt in a rat pancreas cell also showing the 4 components that make up the mt (Becker et al., 2003). 


\subsubsection{Mitochondrial Genetics}

The mt chromosome or mtDNA is a circular, double-stranded molecule that is maternally inherited. Human mtDNA is thought to contain 37 genes and is $\sim 17 \mathrm{~kb}$ in size (Figure 1.2). There are many mt chromosome copies per mt, often hundreds or thousands, depending on the type of cell (Pulkes and Hanna, 2001). In higher eukaryotes, there are 13 nuclear-encoded genes, which code for proteins that are directly involved in mt respiratory chain (Garcia et al., 2007).

In the yeast Saccharomyces cerevisiae, about 1-45 $\mathrm{mt}$ can be found in a typical haploid cell. $S$ cerevisiae's mt DNA is $\sim 78 \mathrm{~kb}$ in size (Figure 1.2) (Griffiths et al., 2000). There are 11 genes that produce polypeptides involved in the mt respiratory chain, eight of which are encoded by nuclear genes. The exact roles of all these genes are not well described but many are thought to be involved in enzyme assembly and stability. Three proteins (Cox $1 p, \operatorname{Cox} 2 p$ and $\operatorname{Cox} 3 p)$ are encoded by $\mathrm{mt}$ genes and are translated inside the $\mathrm{mt}$ by $\mathrm{mt}$ ribosomes or mitoribosomes. These 3 endogenous proteins are a part of complex IV of the respiratory chain found in the inner $\mathrm{mt}$ membrane (Figure 1.3) (Horan et al., 2005). The respiratory complexes are conserved from yeast $S$ cerevisiae to human with the exception of complex I, which is replaced by three NADH dehydrogenases in $S$ cerevisiae (Lemaire and Dujardin, 2008).

There are two main roles for mtDNA: to code for proteins that make up the OXPHOS system, and to code for transfer RNAs (tRNAs), ribosomal RNAs (rRNAs), and other proteins used in mt protein synthesis. Most mt proteins of eukaryotic cells are encoded by nuclear genes, synthesized by cytoplasmic ribosomes, and then transported into the $\mathrm{mt}$ via specialized import system (Foury and Kucej, 2001). 
Yeast mitochondrial DNA $(-78 \mathrm{~kb})$

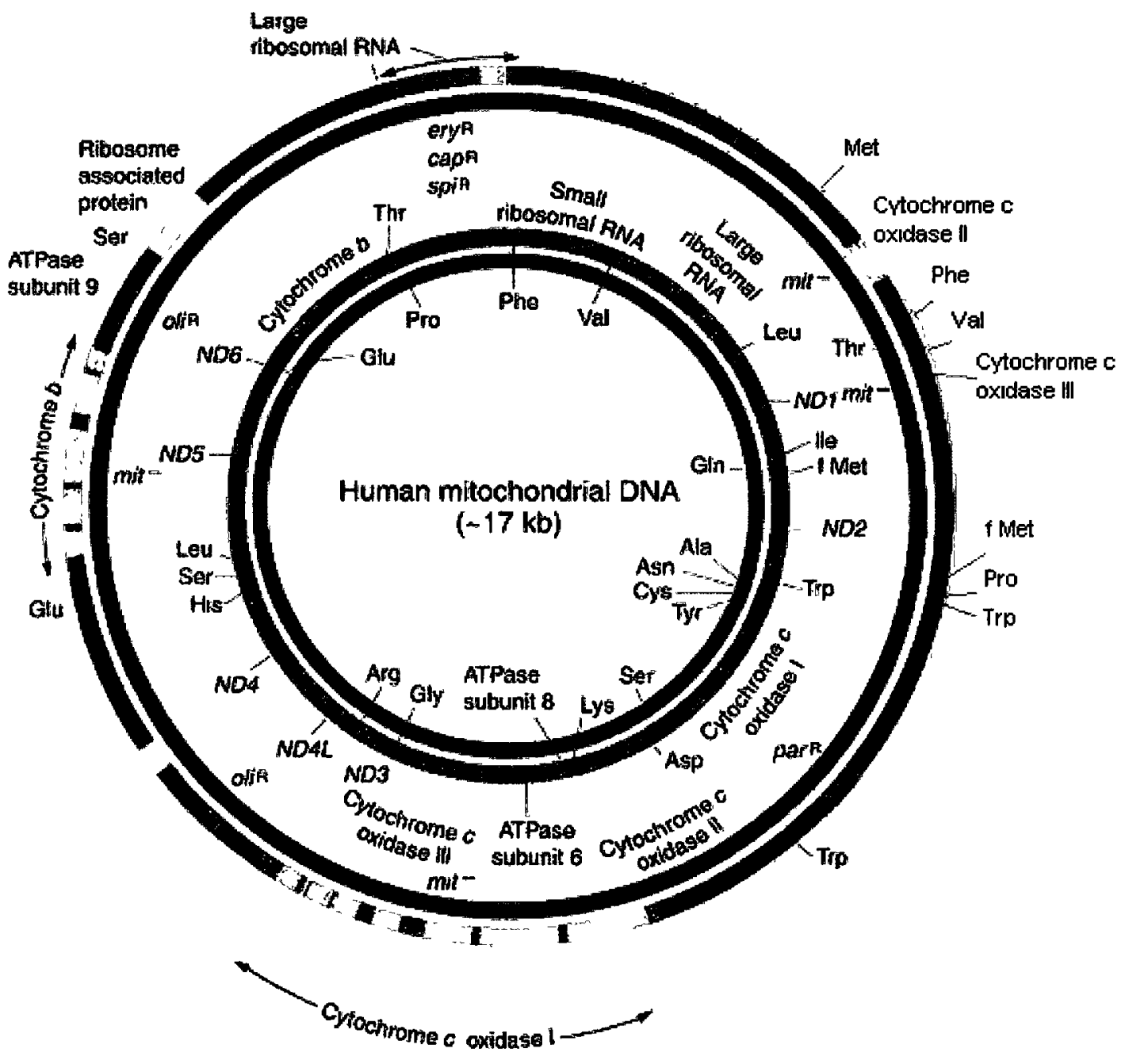

Figure 1.2: Maps of yeast and human mtDNAs showing the circular double-stranded nature of the DNA. As shown, yeast mtDNA is $\sim 4$ times larger than human mtDNA (modified from Griffiths et al., 2000). 


\subsubsection{Energy Production}

The survival of most aerobic cells, tissues and organisms depends on their ability to use oxygen to extract energy. This occurs through a series of metabolic reactions referred to as OXPHOS. In eukaryotes, energy is produced, in form of adenosine triphosphate (ATP), by first converting glucose to pyruvate through a process called glycolysis that occurs in the cytoplasm. Pyruvate is then transported across the mt inner membrane to be oxidized to carbon dioxide $\left(\mathrm{CO}_{2}\right)$ via a process called Krebs cycle, which also generates NADH and $\mathrm{FADH}_{2}$ (Kurland and Andersson, 2000). These coenzymes store energy that is extracted by OXPHOS, the final biochemical pathway that produces ATP. Electrons are passed on from these coenzymes to oxygen $\left(\mathrm{O}_{2}\right)$, which is then reduced to water $\left(\mathrm{H}_{2} \mathrm{O}\right)$ in a series of redox reactions termed the electron transport chain (ETC) (Figure 1.3). These reactions provide enough energy that would pump the protons $\left(\mathrm{H}^{+}\right)$from the matrix, across the inner membrane, and into the intermembrane space. This $\mathrm{H}^{+}$gradient creates an electrochemical gradient that causes ATP synthase to phosphorylate adenosine diphosphate (ADP) forming ATP (Tuppen et al., 2010).

The OXPHOS machinery is made up of over 80 different polypeptides, organized into 5 trans-membrane complexes. The ETC is made up of 5 complexes (Subunits I-V) and are embedded in mt inner membrane. Of the 13 nuclear-encoded $\mathrm{mt}$ genes (subunits) mentioned above, seven are involved in complex I, one is involved in complex III, three are involved in complex IV, and two are involved in complex V. Cytochrome $c$ is found on the outer surface of mt inner membrane and is an essential component of the ETC. It transfers electrons between complex III and IV. If significantly altered or removed from the system, the ETC is blocked and energy production stalls (Lemaire and Dujardin, 2008). 


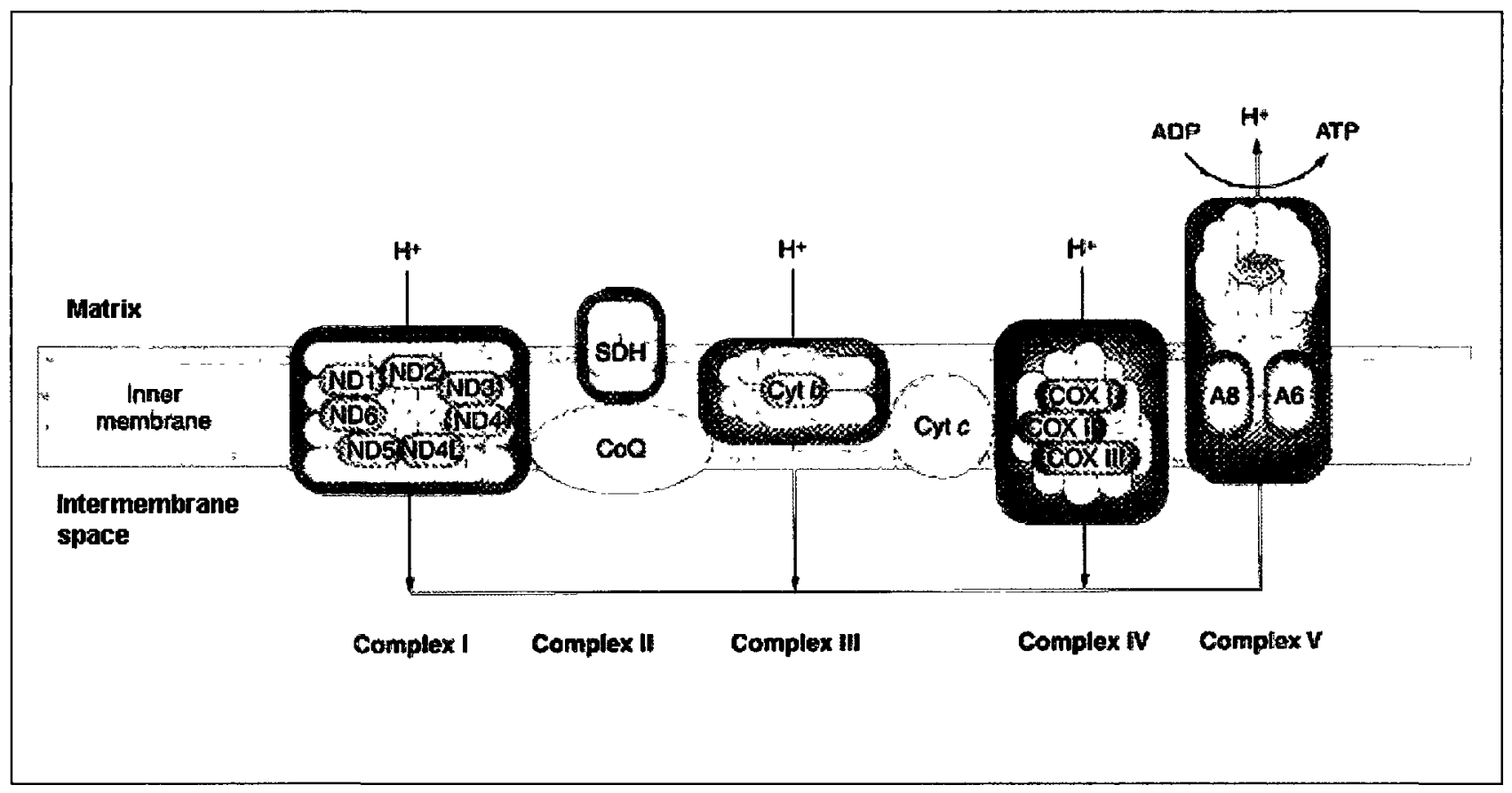

Figure 1.3: A schematic diagram of the mitochondrial electron transport chain (Mt ETC) showing its 5 complexes and cytochrome $c$. Arrows indicate the electron flow as they get passed on from the first complex to the fifth complex, where $\mathrm{O}_{2}$ acts as a terminal electrons acceptor and reduces them to $\mathrm{H}_{2} \mathrm{O}$. This redox reaction generates energy that drives $\mathrm{H}^{+}$from the matrix, across the inner membrane, and into the intermembrane space. An electrochemical gradient is then created to produce ATP from ADP (modified from Griffiths et al., 2000). 


\subsubsection{Mitochondria Malfunction}

Like nuclear DNA, mtDNA is also vulnerable to genetic mutations. In fact, basesubstitutions rate is approximately 10 times higher than that of nuclear genes. This is thought to be as a result of mtDNA not having protective histones that are found in nuclear DNA (Carraway et al., 2008). There are many factors that might be involved in mt dysfunction. Such factors include: base-substitutions, point-mutations (single base substitutions), large deletions in mtDNA, defects in the chaperoning proteins, and flaws in protein import mechanisms (Medeiros, 2008).

Many mtDNA changes are expressed as abnormal phenotypes at the cellular and organismal level. Gene mutations that affect the OXPHOS process lead to respiratory defects that severely compromise the generation of energy in cells and tissues (Smeitink et al., 2001).

Another key function of $\mathrm{mt}$ is regulating apoptosis or programmed cell death. Apoptosis is the physiological mechanism of programmed cell death. This mechanism is vital to a healthy cell cycle. When it is time for the cell to die, a series of events are activated to ensure efficient execution of cell death (Blackstone and Green, 1999).

The mt-dependent apoptotic pathway is activated by diverse stimuli including DNA damage, heat shock, UV and gamma radiation, as well as chemotherapeutic drugs. These stimulating stressors activate some $\mathrm{mt}$ signaling pathways that result in permeabilization of the $\mathrm{mt}$ outer membrane and release of soluble proteins from the $\mathrm{mt}$ inter-membrane space. The release of a number of these proteins has been shown to trigger apoptosis. An example of such proteins is cytochrome $c$ subunit, which relocates to the cytoplasm and couples with other proteins to help initiate apoptosis (Pradelli et al., 2010). 
In many instances when a malfunction occurs in $\mathrm{mt}$ genes associated with apoptotic regulation, the apoptotic mechanism can become unregulated and dysfunctional. In neural cells this can lead to premature cell death which is the main feature of many neurological disorders. Mt disorders can occur in association with genetic abnormalities of either nuclear or mt origin (Szewczyk and Wojtczak, 2002).

Since each mt contains many copies of mtDNA and there are a number of $\mathrm{mt}$ in a cell, both normal and mutant mtDNAs may co-exist in different proportions. Higher proportions of mutant alleles contribute to disease severity (Jensen et al., 2000).

\subsubsection{Mitochondrial Diseases}

Many metabolic and neurodegenerative disorders are now known to be associated with deficient $\mathrm{mt}$ genes. Environment factors may also play a role in the genetically predisposed mtDNA that are related to $\mathrm{mt}$ disorders (Wallace, 2005). The number of $\mathrm{mt}$ per cell is related to cell energy demands. Generally, there are more $\mathrm{mt}$ in cells found in tissues and organs that require more energy to function, such as the brain (Sack Jr., 2009). When mt become nonfunctional, usually a threshold is reached before the disease symptoms appear and as the number of nonfunctional $\mathrm{mt}$ is increased, so does the severity of the symptoms. Examples of such diseases are Parkinson's, Alzheimer's, diabetes, etc. (Wallace and Fan, 2010).

Parkinson's disease (PD) occurs due to neuronal death in the cells of the midbrain, which produce neurotransmitters dopamine (DA), noradrenaline (NA), serotonin (5-HT), and acetylcholine (ACh). Specifically, the disease is characterized by a slow and progressive largescale loss of DA neurons in the substantia nigra (SN) that is found in the midbrain, and the formation of protein aggregates that accumulate in the cytoplasm of the remaining DA neurons 
(Kortekaas et al., 2005). Clinically, patients have the symptoms of progressive rigidity, bradykinesia (slow movement), tremor and postural instability (Banerjee et al., 2009).

Alzheimer's disease (AD) is a progressive neurodegenerative disorder that affects about $10 \%$ of the population after the age of 65 . The disease is characterized by 3 major pathological syndromes: senile plaques, neurofibrillary tangles, and inflammation. The most common symptom of $\mathrm{AD}$ is memory loss, and in advanced stages, dementia (Bouras et al., 2005).

A defined cause for the development of these diseases is unknown. However, there are many factors thought to be involved in their pathogenesis most notably mt dysfunction and oxidative stress:

Mt complex I is the first enzyme of the respiratory chain and the main source of free radicals in the cell. The respiration chain consumes nearly all of molecular oxygen, leaving powerful oxidants as byproducts (Schulz and Falkenburger, 2004). In PD, the inhibition of the respiratory chain, usually due to mtDNA mutation, leads to an increase in the production of reactive oxygen species (ROS), such as superoxide $\left(\mathrm{O}_{2}\right)$ (Yoritaka et al., 1996). When an electron escapes from the $\mathrm{mt}$ ETC it may react with oxygen molecule to form ${ }^{\circ} \mathrm{O}_{2}$, which is converted to hydrogen peroxide $\left(\mathrm{H}_{2} \mathrm{O}_{2}\right)$ and other ROS. These reactive toxic metabolites may have a dramatic effect on $\mathrm{mt}$ and the cell as a whole by eliciting a cascade of events leading to mutation and apoptosis (Figure 1.4). The metabolism of DA also generates ROS, which can lead to oxidative damage that cause neurodegeneration (Stuart and Brown, 2006). In AD, an increase in ROS levels in the system is thought to cause mutations in $\mathrm{mt}$ genome. This leads to a decrease in cytochrome $c$ oxidase activity, the terminal complex of the $\mathrm{mt}$ respiratory chain, resulting in neuronal degeneration (Howell et al., 2005). 


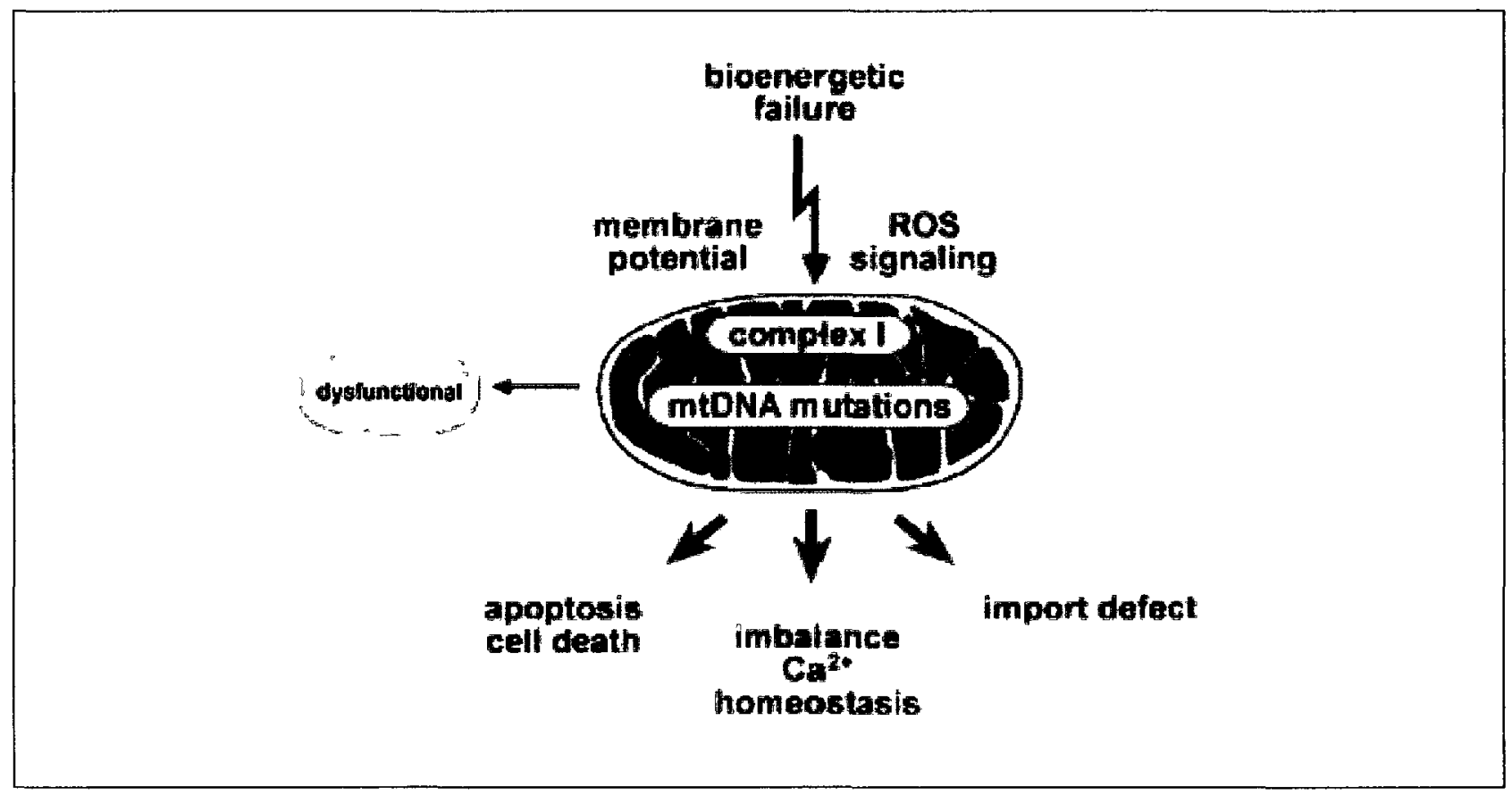

Figure 1.4: A schematic representation of $\mathrm{mt}$ alterations associated with $\mathrm{mtDNA}$ mutations. Respiratory chain malfunctions and MtDNA mutations unleash a series of effects, including an increase in the levels of ROS in the cell. These chain reactions directly affect $\mathrm{mt}$ key functions such as energy metabolism, apoptosis, calcium homeostasis, and cellular quality control pathways. Ultimately, neurons begin to deteriorate leading to the development of neurological diseases such as AD and PD (modified from Winklhofer and Haass, 2010). 
Healthy cells maintain a certain level of intracellular ROS to keep a balanced redox. They do so by releasing and regulating metabolic enzymes or "antixodiants" such as superoxide dismutase (SOD) to break down and eliminate ROS (Pelicano et al., 2003).

Epidemiological studies have shown a strong role for environmental factors in the etiology of many mt-associated diseases such as AD. Exposure to agricultural chemicals such as pesticides has been linked to increased percentage of PD and AD in humans (Schapira, 2010).

Recent evidence confirmed that there are several PD-associated genes which intersect with pathways that regulate $\mathrm{mt}$ function. One of the genes involved in PD development is parkin $(\mathrm{PRKN})$. It is known that a mutation in this gene causes a premature termination of its translation. This loss-of-function mutation is found to contribute to the pathogenesis of $\mathrm{PD}$, as well as mt damage (Gasser, 2009). Another PD-causing gene is PTEN induced putative kinase 1 (PINK1). The PINK1-PRKN pathway is found to be involved in the protection of $\mathrm{mt}$ integrity and function. Therefore, any mutation or disturbance in this pathway strongly impacts the $\mathrm{mt}$ and PD pathogenesis (Park et al., 2009).

To understand the biological roles of PINK1 and PRKN, animal knockout models of PD were created by inactivating these two genes in mice. Whitworth and Pallanck describe the observations in such knockout models. The mice showed nigrostriatal physiological defects suggesting a role for PINK1 and PRKN in DA neurotransmission. They also had enlarged and swollen $\mathrm{mt}$ in tissues that were missing PINK1 and PRKN, suggesting that these genes influence mt integrity (Whitworth and Pallanck, 2009).

To date, there is no cure for either of these disorders. Patients depend completely on symptomatic relief treatments and drugs that slow the disease progress (Winklhofer and Haass, 2010). 
Diabetes mellitus is a disease that occurs with persistent high sugar levels (hyperglycemia) in the blood. This results from defective secretion or action of the hormone insulin. Insulin is secreted by $\beta$ cells in the pancreas to regulate carbohydrate metabolism. There are two forms of this disease: type 1 , also called juvenile diabetes, and type 2 , which usually occurs in adults. Type 1 occurs when children are born with very little or no insulin production in their system. Therefore, they need to receive insulin injections for life. This form is considered rare (Lazar, 2005). Type 2 occurs when body tissues either become resistant to insulin, or when insulin production decreases dramatically. This form is the most common metabolic disease and its side effects include blindness, renal disease, and loss of limb (Lowell and Shulman, 2005). The skeletal muscle and liver maintain normal glucose levels in the blood by signaling insulin to convert glucose to glycogen that can be stored in the muscle and liver. Defects in the skeletal muscle and liver lead to resistance towards insulin (Petersen et al., 2003). Mt regulate insulin secretion from pancreatic $\beta$ cells by detecting glucose levels. Thus any breakdown in this mechanism can lead to hyperglycemia and type 2 diabetes (Lowell and Shulman, 2005). Recently, evidence has linked resistance to insulin with impaired mt function, which is mainly on the basis of insufficient supply of energy to the insulin signaling pathway. Wang et al. were able to impair $\mathrm{mt}$ function by chemical treatment or genetic manipulation, which led to insulin insensitivity and decreased glucose utilization of adipose tissue in mice, rats and humans (Wang et al., 2010). This strongly suggests that mt dysfunction is associated with type 2 diabetes. Furthermore, the pathological changes due to $\mathrm{mt}$ dysfunction can lead to disturbance of glucose homeostasis and type 2 diabetes in animals and humans. Another study that used a mouse model to explore mt dysfunction in type 2 diabetes found a decrease in the number of $\mathrm{mt}$, contents of mtDNA, and respiratory enzymes. It also reported a disturbance of $\mathrm{mt}$ 
network, which is consistent with the decline in the OXPHOS and $\beta$-oxidation in the adipose tissues of the mice with type 2 diabetes (Choo et al., 2006).

\subsection{Yeast as a Model Organism}

Yeast $S$ cerevisiae genome is the first fully-sequenced eukaryotic genome. Its genetic system is thought to highly resemble that in humans (Hurowitz et al., 2003). S cerevisiae is a unicellular facultative anaerobic fungus; qualifying traits of a suitable organism for biochemical and genetic studies of $\mathrm{mt}$ gene expression and respiratory metabolism. Yeast is easily grown, inexpensive to maintain, and is exceptionally amenable to genetic manipulations (Daum, 2000).

$S$ cerevisiae contains approximately 6000 genes, characterized by the genome sequencing project. Approximately 1000 genes are known to have indispensible specific functions and hence are referred to as "essential" genes. The majority of the essential genes are well-characterized. The remaining 5000 genes are identified as "nonessential" genes given that their deletion does not lead to a lethal phenotype (Goffeau et al., 1996). A significant number of these non-essential genes are not yet fully characterized. Numerous studies are currently focused on yeast functional genomics and proteomics to better understand gene function and the functional relationship between genes, proteins, pathways and complexes in yeast (Tong et al., 2004). Recent genome-wide yeast analyses continue to provide important information about how a cell works as a system. This information can lead to our better understanding of complex diseases such as cancer and diabetes (Boone et al., 2007).

Yeast genes share significant sequence identities with $30 \%-40 \%$ of the human diseaseassociated genes, making yeast an important model organism to study human diseases. These conserved genes are generally associated with a number of essential cellular mechanisms, such 
as DNA replication, recombination and repair, RNA transcription, and translation (Mager and Winderickx, 2005).

Moreover, genome-wide analysis identified 466 genes whose deletion impaired $\mathrm{mt}$ respiration. Many of these genes were linked to human mt disorders making yeast an ideal organism to study mt-associated human diseases (Schwimmer et al., 2006). An example of this is the use of yeast in studying PD disease.

Numerous studies have further substantiated the usefulness of yeast to study human mt diseases (Steinmetz et al., 2002). For example, in mammalian cells, complex I is the largest complex within the respiratory chain and consists of at least 45 subunits. In bacteria, fungi and plant, complex I consist of one subunit only (Carroll et al., 2006). In mt of yeast $S$ cerevisiae there are 2 types of NADH dehydrogenases (Ndi1): internal and external. The internal complex (Ndi) is facing the matrix and catalyzes NADH oxidation in the matrix, and the external enzyme (Nde) is facing the inter membrane space and oxidizes NADH in the cytoplasmic space. Marella et al recently proposed that yeast Ndil can restore NADH oxidation in impaired mammalian complex I. They were able to show perfect functional integration of yeast Ndil protein into the mammalian respiratory chain which is highlighted by the repair of ATP production, without any side effects. As a result, they were able to reduce PD symptoms progress in patients (Marella et al., 2009). 


\subsubsection{Translation and Mitochondria}

Gene expression is the process by which information from a gene is converted into functional structures, or proteins, in the cell. This means that by controlling gene expression, cellular functions can be controlled (Berg, 2002).

Translation is part of the overall process of gene expression and is the process by which genetic information is converted from messenger RNA (mRNA) to proteins. This occurs in three steps: initiation, elongation and termination (Bauerschmitt et al., 2008). In eukaryotes, a scanning model for translation initiation states that the small (40S) subunit of eukaryotic ribosome first binds to the mRNA at its capped 5'-end, and then scans the mRNA until it reaches the first start codon AUG, which triggers the initiation of translation (Kozak, 2005). Next is the elongation phase where the mRNA moves along the ribosome, reading one codon at a time. Translation ends when the ribosome reaches one of the three stop codons UAA, UAG, or UGA (Lodish et al., 2000).

In prokaryotes, mRNAs are not capped at the 5' end. Instead, they show sequence conservation from positions -20 through +13 (positions are relative to the start codon at +1 ). The small (30S) subunit of prokaryotic ribosomes binds to the mRNA at a specific site, referred to as Shine-Dalgarno sequence. This sequence is usually 6-9 base pairs (bp) long, including a consensus sequence of 6bp (5'-AGGAGG-3') (Gualerzi and Pon, 1990). It is generally located 8-9bp upstream of the start codon. In Escherichia coli, the Shine-Dalgarno sequence is $7 \mathrm{bp}$ long (5'-AGGAGGU-3'). This sequence is complementary to the anti-Shine-Dalgarno sequence found at the 3' end of the 16S rRNA in the ribosome. After the binding of the ribosome to the mRNA, protein synthesis is initiated (Mori et al., 2007). The tRNAs arrive at the 2 sites on the ribosome: the A and P sites. The A site is the entry point for the aminoacyl tRNA (except for the 
first aminoacyl tRNA, fMet-tRNA ${ }_{\mathrm{f}}^{\text {Met }}$, which enters at the $\mathrm{P}$ site). The $\mathrm{P}$ site is the biding place for the peptidyl-tRNA carrying the growing polypeptide chain. Each new amino acid is added by the transfer of the growing chain to the new aminoacyl-tRNA (from P site to A site), forming a new peptide bond. The deacylated tRNA is then released from the $\mathrm{P}$ site and the ribosome moves one codon farther along the mRNA, transferring the new peptidyl-tRNA to the $\mathrm{P}$ site and leaving the A site vacant for the next incoming aminoacyl-tRNA (Buchan et al., 2006). When the ribosome reaches one of the three stop codons UAA, UAG, or UGA, release factors recognize the stop codons and thus bind to the A site. The polypeptide chain is then released from the $\mathrm{P}$ site and the ribosomes separate into 2 subunits in a reaction driven by the hydrolysis of a GTP molecule (Sund et al., 2010).

Mt has its own translation machinery. However, only $\sim 1 \%$ of mt proteins are encoded inside $\mathrm{mt}$. The rest of the proteins are imported into the mt by a complex protein import pathway. For this, mt proteins are generated as precursors carrying specific targeting signals that direct them towards $\mathrm{mt}$ (Becker et al., 2008). While mitoribosomes and general translation factors are similar to their prokaryotic counterparts, many features of $\mathrm{mt}$ translation appear to be different from that in either prokaryotic cells or the cytoplasm of eukaryotic cells.

In $\mathrm{mt}$, translation initiation is also based on a sequence signal upstream of the start codon AUG on the mt mRNA, much like Shine-Dalgarno sequence in prokaryotes. However, this signal which is also found on the 5' untranslated region (UTR) of the mRNA, does not seem to have complementarity to the mitoribosome (Folley and Fox, 1991). In addition, translational activators encoded by nuclear genes seem to be required to stimulate the translation of specific mt mRNAs (Mittelmeier and Dieckmann, 1995). 


\subsection{Mitochondria-Associated Gene Therapy}

Due to its importance in the development and progress of a number of diseases, $\mathrm{mt}$ genome has become an important candidate for gene therapy. In general, this technique aims to correct defective disease-causing genes by genetically engineering and introducing the corrected gene into human cells to produce functional proteins (Koene and Smeitink, 2009). There are several generic approaches to gene therapy, including: gene transfer, repair, and knock-out (Collombet and Coutelle, 1998).

Gene transfer involves the replacement of the mutated gene with a healthy copy of the gene. This is done by identifying and isolating the gene of interest, then sending the "normal" gene into the cell to replace the defective one via a carrier, often called a vector. These vectors are either viral or non-viral. Part of the challenge in gene therapy is choosing the most suitable vector for treating a certain disease (Suter et al., 2006). Generally, when the functional gene is inserted into the cell, it produces a protein which then, in case of mt gene therapy, gets sent to the mt. This protein enters the $\mathrm{mt}$ via special import machinery located on the outer $\mathrm{mt}$ membrane (Laurence et al., 2009).

In gene repair, the abnormal gene can either be swapped for a normal gene through homologous recombination or it can be repaired through selective reverse mutation, which returns the gene to its normal function. This method uses single-stranded DNA oligonucleotides (ssONs) that are complementary to the wild-type sequence. They are introduced to the cell to anneal to the mutated target sequence and produce a mismatch. They proceed to fix the mismatched sequence using DNA damage repair pathways (McLachlan et al., 2009). 
Gene knock-out refers to the inactivation of the mutated gene. This is possible by replacing the mutated gene with a non-active gene. In this case, endogenous homologous recombination is often used for the swapping of the genes (Dragatsis and Zeitlin, 2001).

There are many challenges with using gene therapy to treat mt-associated disorders. Some of these challenges include: regulation of introduced genes, application of introduced genes to cells which no longer enter the mitotic phase, and carcinogenic potential of such procedures (Kagawa et al., 2001). Vector size restrictions, host immune response to the introduced gene, incomplete gene inactivation, and a possible interference of the introduced gene with neighboring gene expression are other complications that contribute to challenges of gene therapy (Mueller and Flotte, 2008). Direct introduction of mtDNA is possible; however, to date, it has not been successfully implemented yet. The natural import mechanisms for nucleic acids are only known for a few RNA molecules, including yeast tRNA which has been successfully introduced into $S$ cerevisiae mt (DiMauro and Mancuso, 2007). These methods are primarily aimed at overcoming the barriers of the outer and inner membranes of the mt.

\subsubsection{Study Plan}

\section{Background}

In this study, a possible import of mRNAs into $S$. cerevisiae $\mathrm{mt}$ is explored using the principles of mt-vicinity localization and $\mathrm{mt}$ translation.

In addition to carrying protein coding sequences, mRNAs also bear other information that can affect expression, stability and localization of mRNA. For example, their UTRs hold critical information about regulatory signals used in translation. Also there is evidence that UTRs often carry signals that are needed for subcellular localization of mRNAs (Sylvestre et al., 2003b). 
A mRNA sorting to the vicinity of $\mathrm{mt}$ seems to be crucial for the function of this organelle. It has been previously shown that the 3'-UTR of yeast $O X A 1$ gene is required for the localization of this mRNA to the vicinity of $\mathrm{mt}$. Yeast $O X A 1$ is a nuclear gene whose sequence is conserved from prokaryotes to eukaryotes. It codes for Oxalp, a cytochrome $c$ oxidase assembly protein (Bonnefoy et al., 1994). Using a genome-wide approach, it was discovered that mRNAs containing a certain sequence in their 3'-UTRs appear to be localized near mt. However, due to technical limitations associated with such studies; it is still not clear whether the mRNA enters the mt or it simply attaches to the outside of mt membrane (Marc et al., 2002).

Subcellular RNA localization is used by eukaryotic cells to achieve high local concentrations of proteins. It is also required for efficient import of proteins to the nucleus and organelles in somatic cells. Most of these proteins are targeted to their destination on the basis of signals in their peptide sequences. These localization signals are termed the "postal codes" of mRNAs as they are needed to ensure successful delivery of mRNAs to their destinations. Such "postal codes" are found in the 3'-UTR of a number of genes (Jansen, 2001).

Since more than $98 \%$ of $\mathrm{mt}$ proteins are encoded by the nucleus one may expect that $\mathrm{mt}$ sorting may be needed for some of these mRNA to ensure proper function inside mt. Generally, localizing a mRNA to its site of action is more efficient than protein localization, since one mRNA can be a template for multiple rounds of translation (Fünfschilling and Rospert, 1999).

It has recently been shown that human $O X A 1 \mathrm{mRNA}$ can be sorted to the vicinity of yeast $\mathrm{mt}$ and functionally replace yeast $O X A 1$. In addition, it was shown that this sorting was mediated by yeast proteins that recognize the human $3^{\prime}-\mathrm{UTR}$ of $O X A 1 \mathrm{mRNA}$. It was therefore concluded that the recognition mechanism of OXA1 3'-UTR was conserved throughout evolution and that it was needed for the activity of Oxalp function (Saint-Georges et al., 2001). 
In a separate study, introduction of mutations in the $3^{\prime}$-UTR (158bp) of yeast $O X A 1$ gene showed a complete respiratory deficiency in yeast $\mathrm{mt}$. This was explained by the inability of $O X A 1$ to be sorted near $\mathrm{mt}$, providing further evidence for the activity of $O X A 1 \mathrm{mRNA}$ 3'-UTR in sorting this mRNA near mt (Margeot et al., 2002).

Ribosomes, also referred to as polysomes when translating mRNAs, are generally found in the cytoplasm but they can also be localized to the surface of $\mathrm{mt}$. It is thought that mt-bound polysomes may contribute to mt import of the proteins made by these polysomes (Margeot et al., 2005). These ribosomes are expected to initiate translation like most other eukaryotic ribosomes by binding at the 5'-CAP structure of mRNAs and scanning the mRNA for the first available start codon. However, mitoribosomes are thought to resemble prokaryotic ribosomes and recognize a common feature to all yeast mt mRNA 5'-UTR, which is a highly conserved octanucleotide sequence 5'-UAUAAAUA-3' and hence initiate translation (Green-Willms et al., 1998). This consensus sequence represents a conserved ribosome binding site for mt mRNAs similar to the Shine-Dalgarno sequence in prokaryotic mRNAs.

$S$ cerevisiae $\mathrm{mt}$ mRNA 5'-UTRs are uncapped and contain AUG start codon sequences upstream of the initiator AUG. They also generally contain the conserved consensus sequence as well as a long Adenine/Uracil (A/U)-rich tail (Dunstan et al., 1997).

For example, the 5'-UTR (54bp) of yeast mt COX2 gene was found to be essential for the translation of this gene inside the mt. COX2 codes for cytochrome $c$ oxidase subunit II, the terminal member of mt inner membrane ETC. It is expressed by a nuclearly encoded translational activator protein, Pet111p, which interacts with $C O X 25^{\prime}$-UTR to promote translation. These translation activators tend to be gene-specific (Bonnefoy et al., 2001). 
When $C O X 2$ ribosome binding site was mutated, the translation activity of this mRNA in $\mathrm{mt}$ was eliminated. This finding provided further evidence that mitoribosomes recognize a common feature of the 5'-UTR that is needed for successful recognition of mRNA and translation. Unlike Shine-Dalgarno sequence, this unique octanucleotide sequence does not seem to occur at a fixed distance from the start codon of mRNAs. Also, there is no complement for the sequence at the 3' end of $16 \mathrm{~S}$ rRNA (Green-Willms et al., 1998).

\section{Objective and Study Design}

The objective of this thesis is to investigate our ability to direct a designed mRNA into $S$ cerevisiae $\mathrm{mt}$. This would be done using the principles of $\mathrm{mt} \mathrm{mRNA}$ localization and translation machinery in mt. If successful our long term goal would be to follow the same principles to direct therapeutic mRNAs into human mt.

To this end mRNAs containing reporter $\beta$-galactosidase ( $\beta$-gal) genes are designed with or without 3'- and 5'-UTR that may direct mRNAs into $\mathrm{mt}$ and mediate translation using mitoribosomes. These mRNAs contain the 3'-UTR of yeast $O X A 1$ gene to direct the reporter $\beta-$ gal mRNA into mt. A 5'-UTR derived from yeast $C O X 2$ gene that contain mitoribosomal binding site is used to examine the ability of mitoribosomes to translate the reporter genes that are imported into $\mathrm{mt}$. Several measures, such as the presence of a translation inhibitory structure, are taken to reduce the affinity of cytoplasmic translation machinery to the designed mRNA constructs. 
Chapter 2: Materials and Methods 


\section{CHAPTER 2: MATERIALS AND METHODS}

\subsection{Media Preparation}

Standard sterilization techniques were used in all experiments. All media were stored at $4^{\circ} \mathrm{C}$.

\subsubsection{Luria-Bertani (LB)}

To make 1L of LB media: 10.0g of Bacto-Trypton (Peptone), 5.0g of Yeast Extract, and $10.0 \mathrm{~g}$ of Sodium chloride $(\mathrm{NaCl})$ were dissolved in $1000 \mathrm{ml}$ distilled water $\left(\mathrm{dH}_{2} \mathrm{O}\right)$ and the $\mathrm{pH}$ was adjusted to $\sim 7.5$. The mixture was autoclaved, allowed to cool down, then stored at $4^{\circ} \mathrm{C}$. To make $1 \% \mathrm{LB}$ agar plates; the same ingredients were used as well as $10.0 \mathrm{~g}$ of agar, which was autoclaved separately then mixed and poured in plates.

\subsubsection{Yeast Extract Peptone Dextrose (YPD)}

To make $1 \mathrm{~L}$ of YPD media; 2 flasks were used: in flask $\mathrm{A}, 20.0 \mathrm{~g}$ Peptone and $10.0 \mathrm{~g}$ Yeast Extract were dissolved in $900 \mathrm{ml} \mathrm{dH_{2 }}$ O. In flask B, $20.0 \mathrm{~g}$ of Glucose were dissolved in $100 \mathrm{ml} \mathrm{dH_{2 }} \mathrm{O}$. The flasks were autoclaved separately then mixed.

\subsubsection{Media lacking Uracil (-URA)}

To make 1L of -URA agar plates; 3 flasks were used: in flask A, 6.74g of Yeast Nitrogen Base (YNB) (containing Ammonium sulfate) and 2.0g of-URA Drop out powder were dissolved in $200 \mathrm{ml} \mathrm{dH}_{2} \mathrm{O}$. In flask $\mathrm{B}, 20 \mathrm{~g}$ of Glucose were dissolved in $100 \mathrm{ml} \mathrm{dH}_{2} \mathrm{O}$. Finally, in flask C, $20.0 \mathrm{~g}$ of agar were dissolved in $700 \mathrm{ml} \mathrm{dH_{2 }} \mathrm{O}$. Next, the 3 flasks were autoclaved separately, and then mixed before they were poured, and stored at $4^{0} \mathrm{C}$. To make-URA liquid media; the same ingredients were used without the agar component. 


\subsubsection{Ampicillin}

Stock Amp with a concentration of $50.0 \mathrm{mg} / \mathrm{ml}$ was prepared and stored at $-20^{\circ} \mathrm{C}$. The antibiotic was added to the media to a final concentration of $50.0 \mu \mathrm{g} / \mathrm{ml}$. Therefore, for every $1.00 \mathrm{ml}$ of tempered media, $1.00 \mu \mathrm{l}$ of Amp was added.

\subsubsection{Freezer Stocks}

All freezer stocks were prepared as 2:1 ratio of cells to $60 \%$ glycerol and were stored in $-80^{\circ} \mathrm{C}$.

\subsubsection{Strains and Plasmids}

Strains used throughout the study are listed in Table 2.1.

The expression vector used was p416 GALL (Figure 2.1). It was $\sim 5.5 \mathrm{~kb}$ in size and it contained galactokinase promoter (GALL-pro), and lacZ reporter gene that was cloned as an XbaI/BamHI cassette downstream of the promoters. The plasmid also contained Uracil (URA3) and Ampicillin resistance (Amp) genes for selective growth of yeast and $E$ coli, respectively in minimal media (Mumberg et al., 1994). 
Table 2.1: Strains and plasmids used in this study.

\begin{tabular}{|c|c|c|}
\hline Organism / Plasmid & Strain / Plasmid & Reference \\
\hline Saccharomyces cerevisiae & 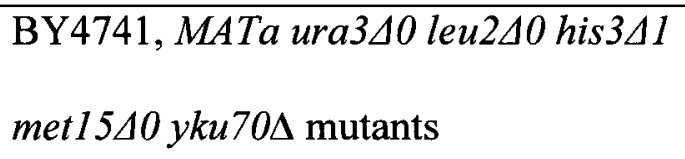 & Alamgir et al (2010) \\
\hline Saccharomyces cerevisiae & $\begin{array}{l}\text { DAN1, MATa ura3 } 30 \text { leu } 2 \Delta 0 \text { his } 3 \Delta 1 \\
\text { met15 } 10 \text { yku } 70 \Delta \text { mutants }\end{array}$ & Alamgir et al (2010) \\
\hline Escherichia coli & 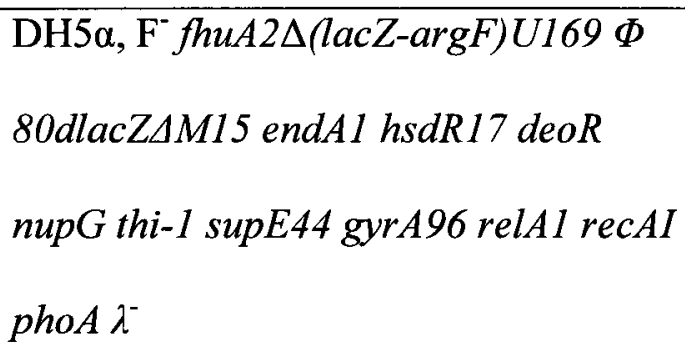 & Bryant et al. (2009) \\
\hline
\end{tabular}




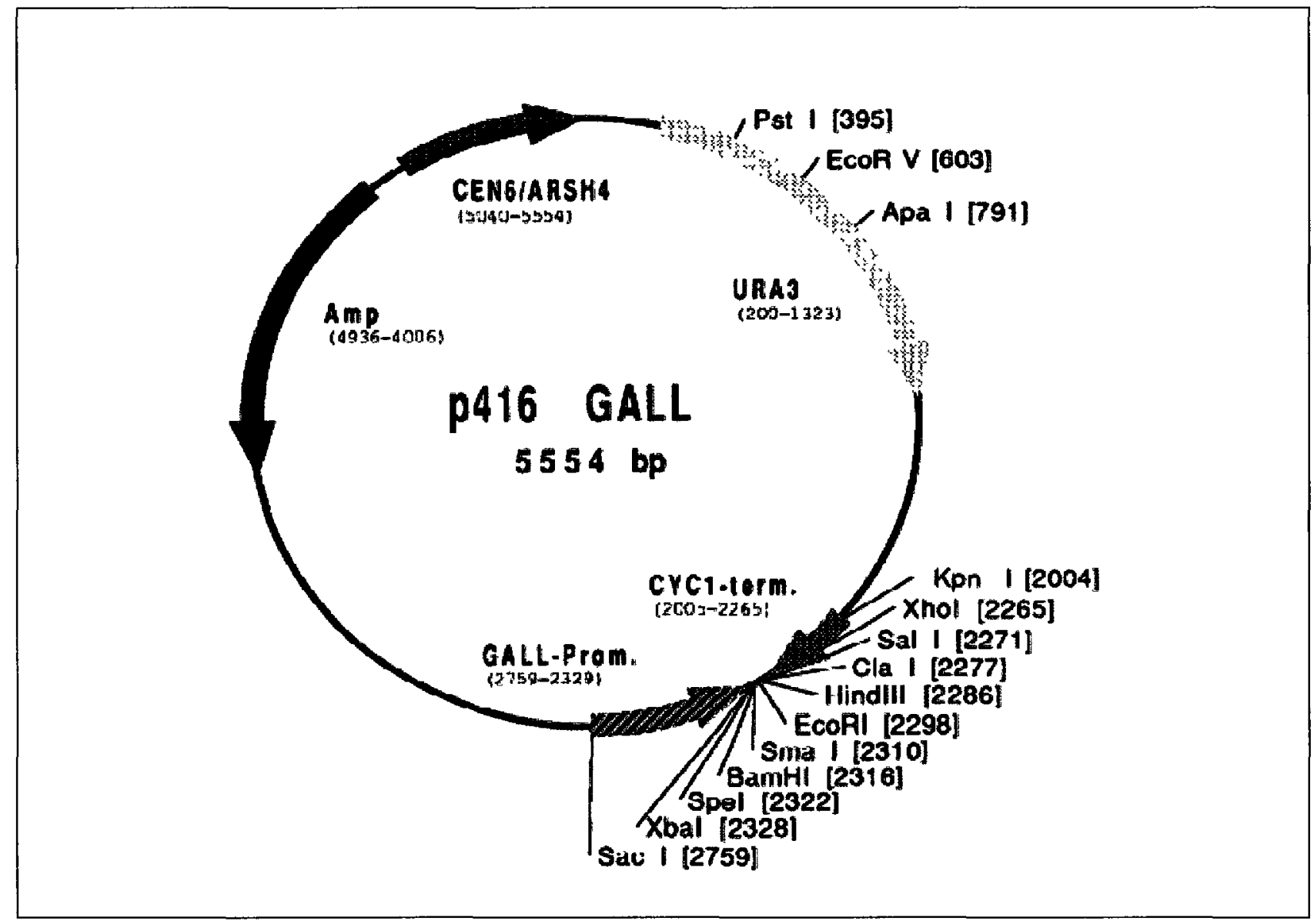

Figure 2.1: Plasmid map of p416 GALL showing its Uracil (URA3) and Ampicillin resistance (Amp) genes, which enable transformed cells to grow in a media lacking Uracil (-URA) and containing Amp, for yeast and $E$. coli selection, respectively. The map also shows the location of the GALL promoter (GALL-Prom.) and different restriction enzyme sites (modified from Mumberg et al., 1994). 


\subsection{Molecular Techniques}

\subsubsection{Chromosome extraction}

Standard methodology was used to extract chromosomes from yeast $S$ cerevisiae BY4741 (Sambrook et al., 2000). All yeast strains used were from this background (Table 2.1). The culture was grown in $5.00 \mathrm{ml}$ Luria-Bertani (LB) media overnight, in a $30^{\circ} \mathrm{C} / 200 \mathrm{RPM}$ incubator shaker. Chromosome extraction included three basic steps: cell lysis, DNA clean up, and DNA isolation. The cells were lysed by vortexing with glass beads and STET lysis buffer. For every $1.00 \mathrm{ml}$ cell culture, $2.00 \mathrm{~g}$ glass beads were added. Residues bound to DNA were removed by precipitation with Ammonium acetate $\left(\mathrm{C}_{2} \mathrm{H}_{3} \mathrm{O}_{2} \mathrm{NH}_{4}\right)$. Finally, DNA was precipitated in ice cold ethanol (EtOH), since it is insoluble in alcohol.

\subsubsection{Polymerase Chain Reaction (PCR)}

Polymerase Chain Reaction (PCR) was performed following standard methodology. The three steps of PCR include: denaturing the double stranded DNA, annealing the primers to DNA templates, and extending the newly synthesized strand to form a semi conservative double stranded DNA. Denaturation step was set up at a very high temperature to break the bonds holding the nitrogen bases in DNA. This was performed at the temperature of $95^{\circ} \mathrm{C}$ for $1 \mathrm{~min}$. Annealing step was set up at a low temperature to allow the primers to attach themselves to single stranded DNA templates $\left(2\right.$ minutes at $\left.52^{\circ} \mathrm{C}\right)$. Finally, elongation step was set up at a medium temperature to allow the thermostable DNA enzyme to copy the DNA strands in the $5^{\prime} \rightarrow 3^{\prime}$ direction $\left(4\right.$ minutes at $\left.72^{\circ} \mathrm{C}\right)$. This enzyme catalyzes the polymerization of deoxyribonucleotides into a DNA strand, leaving amplified DNA products with Adenine (A) overhangs at their 3' ends. The three step reaction was repeated 30 times. Each PCR cycle doubles the amount of DNA exponentially. 
In these experiments, isolated yeast DNA was used as a template and Taq DNA polymerase was used as a catalytic enzyme. A combination of three short DNA fragments (primers) were used (Table 2.2); a 35 base pair (bp) forward and reverse primers (3'-YOXA1UTR-F and 3'-YOXA1UTR-R, respectively), which were complementary to yeast OXA1 3'-UTR, and a 21bp GALL-Pro primer.

PCR product was purified via QIAquick PCR purification kit, using the manufacturer

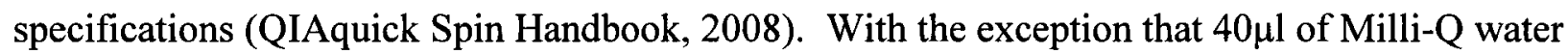
$\left(\mathrm{MQ} \mathrm{H}_{2} \mathrm{O}\right.$ ) was added to the centre of the QIAquick column to elute DNA. 
Table 2.2: Sequences for 3' primers used in PCR.

\begin{tabular}{|l|l|}
\hline \multicolumn{1}{|c|}{ Oligonucleotide name } & Sequence $\left(5^{\prime} \rightarrow 3\right)$ \\
\hline 3'-YOXA1UTR-F & CGCGGATCCATTAATAACAAAAAATGAATAAAGGC \\
\hline 3'-YOXA1UTR-R & CGC $\underline{ }$ \\
\hline GALL-pro & ATTAACCCTCACTAAAGAATGATTATTTCAAGCAATAAA \\
\hline
\end{tabular}

Legend:

Underlined sequence $=$ Bam $H I$ restriction sites used for cloning 


\subsubsection{Phenol-Chloroform Extraction of Mt RNA}

All solutions were prepared with water treated with Diethyl pyrocabonate (DEPC). To do this, DEPC was added to $\mathrm{MQH}_{2} \mathrm{O}$ at a ratio of $1: 1000$, and the mixture was left at room temperature overnight to allow DEPC to destroy the RNase. The next day, the solution was autoclaved. In a separate tube, $1 \mathrm{ml}$ of DEPC was mixed with $9 \mathrm{ml} \mathrm{EtOH}$ and was added to the DEPC-treated water (final concentration $0.1 \%$ ). The solution was mixed well and was left at room temperature overnight before it was autoclaved again.

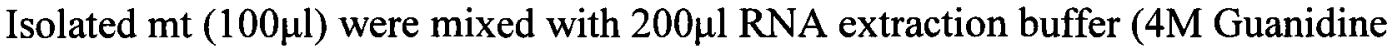
thiocyanate, $25 \mathrm{mM}$ Sodium citrate $(\mathrm{pH} 7.0), 0.5 \%$ Sarcosyl, and $0.1 \mathrm{M} \beta$-mEtOH, with $\beta$-mEtOH added immediately before use), and heated at $65^{\circ} \mathrm{C}$ for $1 \mathrm{~min}$. Next, $30 \mu 12 \mathrm{M}$ sodium acetate

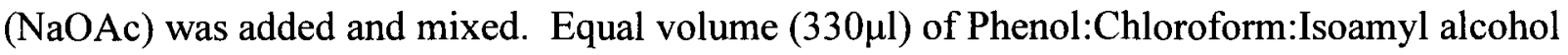
mix (25:24:1) was added to extract crude RNA. Contents of the solution were separated into 3 phases by centrifugation at $12,000 \mathrm{~g}(\sim 14000 \mathrm{RPM})$ for $15 \mathrm{~min}$ at $4^{\circ} \mathrm{C}$. The aqueous phase containing total RNA, which under acidic conditions is usually the top layer, was transferred to a fresh tube. This aqueous phase was then extracted two times with one volume of chloroform $(330 \mu 1)$. Phenol-chloroform extraction was repeated to completely remove DNA and protein contaminations from the interphase and phenol or organic phase, which are usually found in the bottom layer. RNA was precipitated by adding an equal volume $(\sim 330 \mu l)$ of $100 \%$ isopropanol. The tube was inverted a few times to mix the solution and then it was incubated at $-20^{\circ} \mathrm{C}$ overnight. Mt RNA was pelleted by centrifugation at maximum speed for $7 \mathrm{~min}$ at $4^{\circ} \mathrm{C}$. The supernatant was discarded and the pellet was washed briefly with $1 \mathrm{ml}$ of cold $70 \% \mathrm{EtOH}$ by vortexing and then centrifuging at maximum speed for $2 \mathrm{~min}$ at $4^{\circ} \mathrm{C}$. EtOH was gently removed with a fine pipette tip. After that, the pellet was allowed to air dry by inverting the tube on a 
paper towel in the incubator at $37^{\circ} \mathrm{C}$ for $1-5 \mathrm{~min}$. Finally, mt RNA was resuspended in $50 \mu \mathrm{l}$ DEPC $\mathrm{MQH}_{2} \mathrm{O}$ then stored at $-80^{\circ} \mathrm{C}$.

\subsubsection{Reverse Transcriptase Polymerase Chain Reaction (RT-PCR)}

RT-PCR reaction consists of 2 steps: complementary DNA (cDNA) synthesis, and real time PCR. In cDNA synthesis, $m t$ RNA samples $(15 \mu l)$ were mixed with the reagents from BioRad RT-PCR kit, according to the manufacturer's specification $(4 \mu 15 x$ iScript Reaction Mix, $1 \mu l$ iScript Reverse Transcriptase, and $15 \mu 1$ Nuclease free water). The mixture was incubated first at $25^{\circ} \mathrm{C}$ for $5 \mathrm{~min}$., and at $42^{\circ} \mathrm{C}$ for $30 \mathrm{~min}$., following a third incubation at $85^{\circ} \mathrm{C}$ for $5 \mathrm{~min}$., and finally briefly at $4^{\circ} \mathrm{C}$. In real time PCR phase, $5 \mu$ l of cDNA was added to a mixture of BioRad reagents (10 $\mu \mathrm{l}$ IQ SYBR green supermix, $6 \mu \mathrm{MQ} \mathrm{MQH}_{2} \mathrm{O}, 2 \mu 1$ Forward primer 1 (MA-LacZ F 5'-TTGAAAATGGTCTGCTGCTG-3'), and 2 $\mu 1$ Reverse primer 2 (MA-LacZ R 5'TATTGGCTTCATCCACCACA-3'). The reaction mixture (25 $\mu$ l) was added to a flat-top PCR tube and placed in a RT-PCR cycler (ROTOR GENE RG-3000 from Corbett research). The reaction ran for 44 cycles as follows: $30 \mathrm{sec}$. hold at $95^{\circ} \mathrm{C}$, then $30 \mathrm{sec}$. hold at $55^{\circ} \mathrm{C}$, followed by $20 \mathrm{sec}$. hold at $72^{\circ} \mathrm{C}$. Resulting data were analyzed using Rotor-Gene Real-Time Analysis Software 6.0.14, and RNA concentrations were determined using NanoDrop Nd-100 Fullspectrum UV/Vis Spectrophotometer. 


\subsubsection{Agarose gel electrophoresis}

In brief, in a $200 \mathrm{ml}$ flask: $0.40 \mathrm{~g}$ agarose was diluted in $40.0 \mathrm{ml} 1 \mathrm{X}$ TAE buffer solution and was heated for $1 \mathrm{~min}$. to melt the agarose particles. The mixture was left to cool down to $\sim 50^{\circ} \mathrm{C}$ before adding $2 \mu \mathrm{l}$ of $10 \mathrm{mg} / \mathrm{ml}$ Ethidium bromide $(\mathrm{EtBr}) . \mathrm{EtBr}$ is used to visualize DNA or RNA bands. It fluoresces under UV light when intercalated into DNA or RNA. The gel mixture was swirled and poured onto the tray immediately after. When the gel solidified at room temperature (RT), the comb was carefully removed and samples were loaded into the wells. Samples were mixed with a loading buffer before adding the mixture to the gel. Loading buffer contains Bromophenol Blue which gives the buffer its dark blue colour. The dye is easily visualized when loading samples to the wells as it co-sediments with the DNA. The gel ran for $45 \mathrm{~min}$. to $1 \mathrm{hr}$, at a constant voltage of $80-95 \mathrm{~V}$ and a current of $500 \mathrm{~mA}$. Volumes generally used in agarose gel electrophoresis are listed in Table 2.3. 
Table 2.3: General volumes used in agarose gel electrophoresis.

\begin{tabular}{|c|c|c|c|}
\hline \multicolumn{2}{|c|}{ DNA ladder } & \multicolumn{2}{c|}{ Sample } \\
\hline $100 \mathrm{bp} / 1 \mathrm{~kb}$ DNA ladder & $1 \mu \mathrm{L}$ & Sample & $5 \mu \mathrm{L}$ \\
\hline Loading buffer & $1 \mu \mathrm{L}$ & Loading buffer & $1 \mu \mathrm{L}$ \\
\hline $\mathrm{MQ} \mathrm{H}_{2} \mathrm{O}$ & $10 \mu \mathrm{L}$ & MQ $\mathrm{H}_{2} \mathrm{O}$ & $6 \mu \mathrm{L}$ \\
\hline Total volume & $\mathbf{1 2 \mu \mathrm { L }}$ & Total volume & $12 \mu \mathrm{L}$ \\
\hline
\end{tabular}




\subsubsection{Western Blot}

Western blot analysis was performed over a 2 day period and was composed of the following stages: Sodium Dodecyl Sulfate Polyacrylamide Gel Electrophoresis (SDS-PAGE), blotting, blocking, washing, and visualizing.

\subsubsection{SDS-PAGE}

Standard procedure was used to run an $8 \%$ SDS-PAGE, which is the recommended concentration for a large protein size. SDS-PAGE is composed of 2 gels: resolving and stacking gels. The resolving gel is made first. In a $50 \mathrm{ml}$ Falcon Tube ingredients in Table 2.4 were mixed. Protogel and Protogel buffer are commercially made by National Diagnostics (Catalogue \#EC-890 and EC-892, respectively). Protogel, its buffer, and $\mathrm{MQ} \mathrm{H}_{2} \mathrm{O}$ were added first and swirled to mix. Then $30 \%$ Ammonium per sulfate (APS) (0.30g APS in $1 \mathrm{ml} \mathrm{MQ} \mathrm{H}_{2} \mathrm{O}$ ) and commercially prepared Tetramethylethylenediamine (TEMED) (Bioshop Canada (Cat. \#TEM001.25)) were added. The mixture was quickly swirled and poured into the apparatus until it reached the marked line. A $1.5 \mathrm{~mm}$ Bio-Rad mini gel apparatus with same size combs and glass slides were used in all experiments. Together, APS and TEMED catalyze the polymerization of acrylamide in SDS-PAGE.

While waiting for the resolving gel to solidify, the stacking gel was prepared. In a $50 \mathrm{ml}$ Falcon Tube ingredients in Table 2.5 were mixed in the same manner listed above. Protogel stacking buffer was commercially made by National Diagnostics (Cat. \#EC-893). APS and TEMED were added only when the gel was ready to be poured. 
Table 2.4: Recipe for making an $8 \%$ resolving gel for SDS-PAGE with ingredients listed in order of addition.

\begin{tabular}{|l|c|}
\hline \multicolumn{1}{|c|}{ Ingredients } & $\mathbf{8 \%}(\mu \mathrm{l})$ \\
\hline Protogel & 2136 \\
\hline Protogel buffer & 2080 \\
\hline $\mathrm{MQ} \mathrm{H}_{2} \mathrm{O}$ & 3696 \\
\hline $30 \%$ APS & 28 \\
\hline TEMED & 8 \\
\hline
\end{tabular}


Table 2.5: Recipe for making a stacking gel for SDS-PAGE with ingredients listed in order of addition.

\begin{tabular}{|l|c|}
\hline \multicolumn{1}{|c|}{ Ingredients } & $4 \%(\mu \mathrm{l})$ \\
\hline Protogel & 520 \\
\hline Protogel stacking buffer & 960 \\
\hline $\mathrm{MQ} \mathrm{H}_{2} \mathrm{O}$ & 2440 \\
\hline $30 \%$ APS & 8 \\
\hline TEMED & 4 \\
\hline
\end{tabular}


Once the resolving gel solidified the apparatus was tipped over to drain remaining liquids. The stacking gel was then poured on top of the resolving gel and the comb was inserted immediately. While waiting for the gel to solidify, the rest of the apparatus was assembled and samples were prepared according to the following guideline. Equal amount of loading buffer dye was mixed with protein samples. Dye mix is composed of $95 \%$ Laemmli Sample Buffer (2\% SDS, $25 \%$ Glycerol, $0.01 \%$ Bromophenol Blue, and 62.5mM Tris-HCL, $\mathrm{pH} 6.8$ ) and $5 \% \beta-$ Mercaptoethanol ( $\beta$-mEtOH), purchased from Bioshop Canada (Cat.\# MER002.100). $\beta$-mEtOH is used to denature proteins by reducing the intra and inter-molecular disulfide bonds of the proteins to allow proper protein separation by size. After protein samples were combined with the dye mix, they were heated at $95^{\circ} \mathrm{C}$ for $3-5 \mathrm{~min}$. then centrifuged at max. speed $(15,000 \mathrm{RPM})$ for $5 \mathrm{sec}$.

By this time the stacking gel solidified and the apparatus was ready to use. The comb was slowly removed, and the gel cassette was inserted in the tank, which was then filled with $1 \mathrm{X}$ resolving gel buffer (10X Resolving gel buffer: $250 \mathrm{mM}$ Tris-Base, $\mathrm{MQ} \mathrm{H}_{2} \mathrm{O}, 2500 \mathrm{mM}$ Glycerol/Glycine, and 1\% SDS- $\mathrm{pH} 8.3$ adjusted with $10 \mathrm{M} \mathrm{HCl}$ ). Samples were then loaded into the gel. For $1.5 \mathrm{~mm}$ spacers the lane capacity is $30 \mu \mathrm{l}-40 \mu \mathrm{l}$. Also, $5 \mu \mathrm{l}$ protein ladder (Precision Plus Protein Kaleidoscope Standards from BioRad, Cat. \# 161-0375) was loaded directly into gel, without being heated. The gel ran at RT with a voltage of $140 \mathrm{~V}$ and a current of $137 \mathrm{~mA}$ for $1 \mathrm{hr}$. 


\subsubsection{Blotting}

After running the gel, the following items were soaked in transfer buffer $(20 \mathrm{mM}$ Tris$\mathrm{HCl}, 150 \mathrm{mM}$ Glycine, and 20\% Methanol - $\mathrm{pH} 8.0$ ): 2 transfer sponges, 2 blotting papers, and 1 nitrocellulose membrane cut to the shape and size of the gel. At all time, the nitrocellulose membrane was handled with a clean forceps from one edge only. The "blotting sandwich" was prepared by placing a previously soaked sponge on the black side of the sandwich apparatus. Then a blotting paper was placed over the sponge, followed by the gel. After that, the previously soaked nitrocellulose membrane was placed on top of the gel and another blotting paper was placed over the membrane, followed by another sponge. Air bubbles were pressed out with gloved fingers and the sandwich apparatus was clamped and placed in the correct orientation inside the transfer tank. A stirrer bar and an ice block were also inserted into the tank, which was filled with transfer buffer. Protein samples were allowed to transfer from the gel to the nitrocellulose membrane overnight in the cold room at a constant current of $180 \mathrm{~mA}$.

\subsubsection{Blocking and Washings}

The next day, block solution $(5 \% \mathrm{w} / \mathrm{v})$ was prepared $(2.5 \mathrm{~g}$ skim powder milk and $50 \mathrm{ml}$ TBST detergent buffer (20mM Tris-HCl, $137 \mathrm{mM} \mathrm{NaCl}$, and $0.1 \%$ Tween $20-\mathrm{pH} 7.6)$ in a $50 \mathrm{ml}$ Falcon tube, and kept on ice. Primary (1'AB) and secondary (2'AB) antibodies were prepared by mixing the manufacturer's recommended concentrations of antibody to block solution.

The nitrocellulose membrane, now containing the protein samples, is incubated with block solution and gentle shaking, with the protein side facing upwards, for $1 \mathrm{hr}$ at RT.

Block solution was collected back to the falcon tube, after blocking, and stored in $-20^{\circ} \mathrm{C}$ for re-use. The nitrocellulose membrane was incubated with 1'AB solution and gentle shaking for $1 \mathrm{hr}$ at RT. Afterwards, $1^{\prime} \mathrm{AB}$ solution was collected back into the tube and stored in $-20^{\circ} \mathrm{C}$ 
for re-use. The nitrocellulose membrane was washed with TBST buffer alone for $30 \mathrm{~min}$. while adding new TBST buffer every $5 \mathrm{~min}$. Subsequently, the nitrocellulose membrane was incubated with 2'AB solution and gentle shaking for $1 \mathrm{hr}$. After that, 2'AB solution was collected back into the tube and stored in $-20^{\circ} \mathrm{C}$ for re-use. The block solution, $1^{\prime} \mathrm{AB}$, and $2^{\prime} \mathrm{AB}$ solutions can be re-used 3-10 times or stored in the freezer for 6 months. The nitrocellulose membrane was washed with TBST buffer as described above.

\subsubsection{Visualization}

After the washings, the nitrocellulose membrane was drained on a paper towel before it was placed on a piece of transparent sheet. Chemiluminescent substrate (Pierce Supersignal West Pico or West Femto, Cat. \# PI34080 or PI095, respectively) for detecting Horseradish peroxidase (HRP) conjugated probes was mixed in a microtube $(1.5 \mathrm{ml})$ and pipetted over the whole nitrocellulose membrane surface, with the protein side facing upwards. The membrane was incubated for $5 \mathrm{~min}$. After that, another piece of transparent sheet was placed on top to sandwich the membrane.

The membrane was then exposed to a photographic film for few seconds depending on the strength of protein signals. Protein bands should luminesce on the film. After, the film was placed in the developer (1:5) until the bands start to appear, then it was rinsed with tap water and placed in the fixer (1:10) for few seconds, and was rinsed with tap water.

A CCD camera (Alpha Innotech HD2) was also used to visualize the protein bands and capture a digital image of the western blot. 


\subsection{7 $\beta$-gal liquid assay}

Transformed yeast cells were grown in 5ml -URA liquid media containing glucose overnight at $30^{\circ} \mathrm{C} / 200 \mathrm{RPM}$ incubator shaker. The next day, they were pelleted at $4000 \mathrm{RPM}$

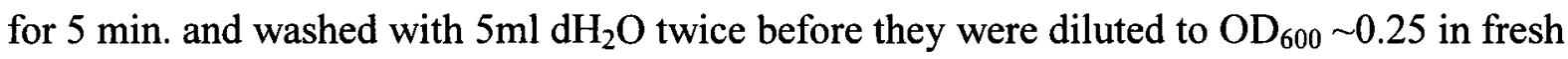
-URA liquid media containing galactose. Cells were incubated at $30^{\circ} \mathrm{C} / 200 \mathrm{RPM}$ until $\mathrm{OD}_{600}$ 1.0. Next, the cells were washed and re-suspended in Z-buffer. Mt were isolated from the samples as described in the next section. The $\mathrm{OD}_{600}$ of suspension was recorded. Then $200 \mu \mathrm{l}$ of mt suspension were mixed with $800 \mu \mathrm{l}$ Z-buffer, $20 \mu \mathrm{l}$ of $0.1 \%$ SDS and $50 \mu \mathrm{l}$ of chloroform. The solution was vortexed for $15 \mathrm{sec}$. before incubation at $30^{\circ} \mathrm{C}$ heat block for $15 \mathrm{~min}$. After that, $200 \mu$ l of ortho-Nitrophenyl- $\beta$-galactoside substrate (ONPG) $(4 \mathrm{mg} / \mathrm{ml}$ stock) was added and the solution was vortexed for $5 \mathrm{sec}$. and incubated $30^{\circ} \mathrm{C}$ heat block. The mixtures were monitored for change of color. When the solution turned yellow the reaction was stopped by adding $500 \mu 1$ $1 \mathrm{M}$ Sodium carbonate $\left(\mathrm{Na}_{2} \mathrm{CO}_{3}\right)$. Then the absorbance at $420 \mathrm{~nm}$ and $550 \mathrm{~nm}$ were measured

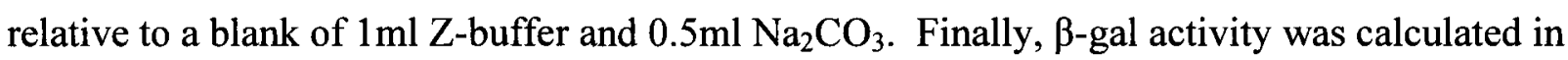
Units as follows:

Unit $=1000 *\left(\mathrm{OD}_{420}-1.75 * \mathrm{OD}_{550}\right) /\left(\right.$ Time $*$ Volume $\left.* \mathrm{OD}_{488}\right)$.

Where,

$U$ refers to units of $\beta$-gal activity

$\mathrm{OD}_{420}$ refers to the optical density of 0 -nitrophenol and cell debris

$\mathrm{OD}_{550}$ refers to the optical density of cell debris

$\mathrm{OD}_{488}$ refers to $\mathrm{mt}$ density in the sample at the start of the assay

$t$ refers to time of reaction in minutes

$\mathrm{V}$ refers to the volume of cell culture used in mille liters 


\subsubsection{Mitochondria Isolation}

Two methods were used to extract $\mathrm{mt}$ from yeast $S$ cerevisiae, the first was accomplished using a "Yeast Mt Isolation kit" (Sigma, MITOISO3), which was supplied with 8 reagents in concentrated form. Yeast $\mathrm{mt}$ was also isolated using a classical approach.

Aliquots of $20 \mathrm{OD}_{600}$ of induced yeast samples were pelleted at $3500 \mathrm{RPM}$ for $7 \mathrm{~min}$. Cells were then washed in 5-6 volumes of water and pelleted again. Next, the pellets were resuspended in $2 \mathrm{ml}$ of $1 \mathrm{x}$ "Buffer $\mathrm{A}$ " and incubated or $15 \mathrm{~min}$. at $30^{\circ} \mathrm{C} / 200 \mathrm{RPM}$ incubator shaker. After that, cells were pelleted at $3000 \mathrm{RPM}$ for $7 \mathrm{~min}$. and resuspended in $1 \mathrm{ml}$ of $1 \mathrm{x}$ "Buffer B". OD $600(110)$ was measured and the total OD of cell suspension was calculated to be used as a reference value. Lyticase concentration was optimized by using 1.5 units of lyticase per OD of cell suspension. Cells were incubated with lyticase at $30^{\circ} \mathrm{C} / 200 \mathrm{RPM}$ incubator shaker and the $\mathrm{OD}_{600(110)}$ was measured every $5 \mathrm{~min}$. to monitor for a $30-40 \%$ decrease in the absorbance from the initial reading. Once the desired absorbance was reached, the reaction was stopped by centrifuging the mixtures at $4500 \mathrm{RPM}$ for $5 \mathrm{~min}$. at $4^{\circ} \mathrm{C}$. The resulting spheroplast pellets were kept on ice before they were resuspended in 1ml "Lysis Buffer" and incubated on ice for $5 \mathrm{~min}$. Then, 2 volumes of $1 \mathrm{x}$ "Storage Buffer" were added to the cells before they were pelleted in a microcentrifuge at $3300 \mathrm{RPM}$ for $10 \mathrm{~min}$. at $4^{\circ} \mathrm{C}$. The supernatant liquid was then transferred into clean sterile microtubes and centrifuged in a microcentrifuge at $13,300 \mathrm{RPM}$ for $10 \mathrm{~min}$. at $4^{\circ} \mathrm{C}$. Finally, the pellets were resuspended in $250 \mu 1$ "Storage Buffer". This "crude $\mathrm{mt}$ " was stored in $-20^{\circ} \mathrm{C}$.

Standard methodology was used to manually isolate $\mathrm{mt}$ from yeast $S$ cerevisiae (Meisinger et al., 2006). Spheroplasts were formed by a combination of enzymatic digestion and differential centrifugation of the yeast cell wall, as described in (Meisinger et al., 2006). 
Spheroplasts were then further purified using free flow electrophoresis (FFE) sample preparation protocol (Zischka et al., 2003). Spheroplasts were suspended in "STP Buffer" (0.6M Sorbitol, 10mM Tris-HCL $\mathrm{pH} \sim 7.4,1 \mathrm{mM}$ PMSF) to a concentration of $0.15 \mathrm{~g} / \mathrm{ml}$. Cell membranes, on ice, were disrupted by vortexing the spheroplasts with acid washed / soda lime glass beads ( same size of pellet) for $15 \mathrm{~min}$. instead of disrupting them with glass Teflon homogenizer. Cell debris was removed by centrifugation at $3750 \mathrm{RPM}$ for $5 \mathrm{~min}$. at $4^{\circ} \mathrm{C}$, twice. Mt was sedimented from the supernatant at $12,200 \mathrm{RPM}$ for $12 \mathrm{~min}$. at $4^{\circ} \mathrm{C}$. Raw $\mathrm{mt}$ fraction was washed (1 volume pellet) with "SET Buffer" (0.25M Sucrose, $1 \mathrm{mM}$ EDTA, $10 \mathrm{mM}$ Tris-HCL pH $\sim 7.4,1 \mathrm{mM}$ PMSF). Supernatant was transferred to a new tube and mt were sedimented at 12,000 RPM for $12 \mathrm{~min}$. at $4^{\circ} \mathrm{C}$. Finally, crude $\mathrm{mt}$ were resuspended in $500 \mathrm{ml}$ "Separation Buffer" and then stored at $-20^{\circ} \mathrm{C}$.

A sample of the isolated $\mathrm{mt}$ was purified by zone electrophoresis using BD Free Flow Electrophoresis (FFE) system, using the manufacturer's specifications (BD Diagnostics, 2007).

\subsubsection{Restriction Digest}

Digestion reactions were prepared and incubated at the temperature for the duration specified by the enzyme manufacturer. For most reactions, mixtures were incubated overnight at $37^{\circ} \mathrm{C}$, and then stored at $-20^{\circ} \mathrm{C}$. An example of a restriction digest reaction is shown in Table 2.6.

Plasmids were purified before and after enzymatic digestion, using QIAquick plasmid purification kit, using the manufacturer's specifications (QIAquick Spin Handbook, 2008). With the exception that $40 \mu \mathrm{l}$ of $\mathrm{MQ} \mathrm{H}_{2} \mathrm{O}$ was added to elute the purified DNA. This step was repeated once more using $20 \mu \mathrm{l}$ of $\mathrm{MQ} \mathrm{H}_{2} \mathrm{O}$. 
Table 2.6: An example of a restriction digest using BamHI enzyme, listed in order of addition.

\begin{tabular}{|l|c|}
\hline \multicolumn{1}{|c|}{ Ingredient } & Volume $(\mu \mathrm{l})$ \\
\hline $\mathrm{MQ} \mathrm{H}_{2} \mathrm{O}$ & 12.2 \\
\hline $10 \mathrm{X}$ Nebuffer BamHI & 2.00 \\
\hline $100 \mathrm{X}$ BSA & 0.20 \\
\hline BamHI & 0.60 \\
\hline DNA & 5.00 \\
\hline Total volume & $\mathbf{2 0 . 0 0}$ \\
\hline
\end{tabular}




\subsubsection{Plasmid Extraction}

Plasmids were extracted from transformed cells via QIAprep Miniprep kit, using the manufacturer specifications (QIAprep Miniprep Handbook, 2006). In sterile microtubes, 1.00ml of cells were added and centrifuged at max. speed (15,000 RPM) for 1 min. The supernatant was discarded, and the process was repeated twice to quantify plasmids extracted. The last step (elution from column) was repeated twice, using $50 \mu$ l of $\mathrm{MQ}_{2} \mathrm{O}$. Isolated plasmids were stored in $-20^{\circ} \mathrm{C}$.

\subsubsection{Ligation}

Ligation trials were set up at the temperature and duration specified by the enzyme manufacturer. For most trials, mixtures were kept in the cold room at $16^{\circ} \mathrm{C}$ water bath overnight, and then stored at $-20^{\circ} \mathrm{C}$. An example of a ligation set up is shown in Table 2.7. 
Table 2.7: An example of a ligation trial with ingredients listed in order of addition.

\begin{tabular}{|l|c|c|c|c|}
\hline \multicolumn{1}{|c|}{ Ingredient } & $\begin{array}{c}\text { Experimental 1 } \\
(\mu \mathrm{l})\end{array}$ & $\begin{array}{c}\text { Experimental 2 } \\
(\mu \mathrm{l})\end{array}$ & $\begin{array}{c}\text { Control 1 } \\
(\mu \mathrm{l})\end{array}$ & $\begin{array}{c}\text { Control 2 } \\
(\mu \mathrm{l})\end{array}$ \\
\hline $\mathrm{MQ} \mathrm{H}_{2} \mathrm{O}$ & 7.70 & 0.20 & 15.7 & 16.9 \\
\hline Ligase buffer & 2.10 & 1.90 & 2.10 & 2.10 \\
\hline BamHI-digested PCR product & 8.00 & 15.8 & 0.00 & 0.00 \\
\hline BamHI-digested p416 & 1.00 & 1.00 & 1.00 & 1.00 \\
\hline Ligase enzyme & 1.20 & 1.10 & 1.20 & 0.00 \\
\hline Total volume & $\mathbf{2 0 . 0 0}$ & $\mathbf{2 0 . 0 0}$ & $\mathbf{2 0 . 0 0}$ & $\mathbf{2 0 . 0 0}$ \\
\hline
\end{tabular}




\subsubsection{Making competent cells}

$E$ coli culture was grown in $5.00 \mathrm{ml} \mathrm{LB}$ media overnight, in a $37^{\circ} \mathrm{C} / 200 \mathrm{RPM}$ shaker incubator. The next day, a fresh subculture was prepared by adding $1.20 \mathrm{ml}$ of overnight cells into $50.0 \mathrm{ml} \mathrm{LB}$ media. The fresh subculture was left in the $30^{\circ} \mathrm{C}$ shaker incubator for few hours (usually $\sim 2 \mathrm{hrs}$ ), until the optical density $\left(\mathrm{OD}_{600}\right)$ of $0.4-0.6$ was reached. Then, $10.0 \mathrm{ml}$ of the fresh subculture were transferred into a falcon tube, and was centrifuged at $4^{\circ} \mathrm{C}$ for $7 \mathrm{~min}$., at $3000 \mathrm{rpm}$. To the pellet, $1.00 \mathrm{ml}$ of ice cold $50 \mathrm{mM}$ Calcium chloride $\left(\mathrm{CaCl}_{2}\right)$ was added. The cells were mixed well before adding more of the ice cold $\mathrm{CaCl}_{2}(6.00 \mathrm{ml})$. The mixture was incubated on ice for $1 \mathrm{hr}$ before it was centrifuged at $4^{\circ} \mathrm{C}$ for $7 \mathrm{~min}$., at $3000 \mathrm{rpm}$. To the pellet, $1.00 \mathrm{ml}$ of the ice cold $\mathrm{CaCl}_{2}$ was added, and the cells were incubated overnight at $4^{\circ} \mathrm{C}$.

\subsubsection{E. coli Transformation}

Overnight competent cells $(150 \mu \mathrm{l})$ were mixed with ligation mixture $(10.0 \mu \mathrm{l}$ of each ligation tube), or target DNA (usually 10-50 ng), by gently swirling the tube. For positive control, $150 \mu$ l competent cells were mixed with $1.00 \mu 1$ of an intact purified plasmid $(10 \mathrm{ng})$. The tubes were incubated on ice for $1 \mathrm{hr}$, and were heat-shocked in a water bath at $42^{\circ} \mathrm{C}$, for $90 \mathrm{sec}$. To each tube, $1.00 \mathrm{ml}$ of $\mathrm{LB}$ media was added, before they were incubated at $37^{\circ} \mathrm{C}$ for $1-1.5 \mathrm{hrs}$. The cells were then centrifuged at max. speed for $1 \mathrm{~min}$. To each pellet, $50.0 \mu \mathrm{l}$ of LB media was added, and the cells were mixed by gently swirling the tube. The contents were plated on LB agar plate containing $50 \mu \mathrm{g} / \mathrm{ml}$ Amp. All plates were incubated at $37^{\circ} \mathrm{C}$ overnight. Transformed cells were screened for by enzymatic digestion followed by fractionation using agarose gel electrophoresis. 


\subsubsection{Yeast transformation}

Yeast were grown in $5.00 \mathrm{ml} \mathrm{YPD} \mathrm{media} \mathrm{overnight,} \mathrm{in} \mathrm{a} 30^{\circ} \mathrm{C} / 200 \mathrm{RPM}$ shaker incubator. The overnight culture was diluted to $\mathrm{OD}_{600} \sim 0.2-0.4$ and was incubated until it reached $\mathrm{OD}_{600} \sim 1.0$. The following was carried out in RT. Cells were pelleted at $3000 \mathrm{RPM}$ for $2 \mathrm{~min}$. and washed with $10 \mathrm{ml} \mathrm{MQH} \mathrm{H}_{2} \mathrm{O}$. They were pelleted again and resuspended in $1 \mathrm{ml} 0.1 \mathrm{M}$ Lithium acetate (LiOAc). Cells were pelleted a third time and resuspended in 200-250 $\mu$ l LiOAc. For each transformation, $50 \mu \mathrm{l}$ of cell suspension were aliquoted to a sterile eppendorf tube (microtube) and the following components were added: $2-5 \mu$ of Rec. p416, 10 $\mu \mathrm{l}$ salmon-sperm DNA (ssDNA), which was boiled for $3 \mathrm{~min}$. and incubated on ice for $5 \mathrm{~min}$. before use, $240 \mu \mathrm{l}$ of $50 \%$ Polyethylene glycol (PEG), and $36 \mu 1$ of $1 \mathrm{M} \mathrm{LiOAc.} \mathrm{The} \mathrm{tubes} \mathrm{were} \mathrm{then} \mathrm{incubated} \mathrm{at} 30^{\circ} \mathrm{C}$ for $1 \mathrm{hr}$. Following incubation, $40 \mu \mathrm{l}$ of Dimethyl sulfoxide (DMSO) was added to each tube, before they were incubated again at $42^{\circ} \mathrm{C}$ for $15 \mathrm{~min}$. Cells were pelleted at $8000 \mathrm{RPM}$ for 2 min., and resuspended in $110 \mu 1 \mathrm{MQH}_{2} \mathrm{O}$. Finally, cells were plated on -URA plates and incubated in $30^{\circ} \mathrm{C}$ for 2 days.

\subsection{Construction of plasmids containing target mRNAs}

DNA was isolated from yeast $S$ cerevisiae and was used as a template in PCR to be amplified by the forward and reverse primers 3'-YOXA1UTR-F and 3'-YOXA1UTR-R, which contain sequences complementary to the target region in the template; the 3'-UTR of yeast $O X A$. The resulting PCR product was purified via QIAquick PCR purification kit. The Purified PCR product was then digested with $B a m H I$, to create sticky ends, for $4 \mathrm{hrs}$ at $37^{\circ} \mathrm{C}$, and then stored at $-20^{\circ} \mathrm{C}$. 
Plasmid p416 was purified via QIAquick plasmid purification kit. The purified plasmid was digested with $B a m H I$ for $4 \mathrm{hrs}$ at $37^{\circ} \mathrm{C}$, and then stored at $-20^{\circ} \mathrm{C}$. The completion of restriction digestion reaction with purified PCR product and plasmid was confirmed on an agarose gel.

The digested PCR product and the plasmid were purified for a second round using QIA purification kits as above. Purified PCR product and plasmid were then ligated overnight in the cold room at $16^{\circ} \mathrm{C}$ water bath, and then stored at $-20^{\circ} \mathrm{C}$.

Ligated plasmids were transformed into $E$. coli DH5 $\alpha$. The obtained $E$ coli colonies were screened for recombinant plasmids. For this, plasmids were extracted from individual colonies and first digested with $\mathrm{BamHI}$ for $4 \mathrm{hrs}$ at $37^{\circ} \mathrm{C}$. The digested plasmids were visualized on a $1 \%$ agarose gel. Those that appeared to have an insert were subjected to a second screening test by digesting with $\mathrm{ClaI}$ overnight at $37^{\circ} \mathrm{C}$. Agarose gel (1\%) electrophoresis was performed after the digestion to screen for a difference in band sizes. The recombinant plasmids carrying the inserted $3^{\prime}-\mathrm{UTR}$ sequence were stored at $-20^{\circ} \mathrm{C}$ to be used in subsequent experiments.

The 5'-UTR primers were designed based on Kozak's hair pin theory (1989a). The structure was $111 \mathrm{bp}$ and consisted of the following; a complement of the Xbal overhang, a hairpin loop, an ATG start codon and the Kozak sequence, a stop codon, and the mt translation initiator gene; $\operatorname{COX} 2$ (Table 2.8). 
Table 2.8: Sequence for single-stranded 5' primer.

\begin{tabular}{|c|c|}
\hline Oligonucleotide & Sequence $\left(5^{\prime} \rightarrow 3^{\prime}\right)$ \\
\hline 5'TI COX2-a & $\begin{array}{l}\text { CTAGCCAGCTTACGCCCGCCAAACAGGCGGGCGTAAG } \\
\text { CTGACC OCGIATAGTATTAACATATTATAAATAGA } \\
\text { CAAAAGAGTCAAAGGTAAGATTATTAAAATGC }\end{array}$ \\
\hline 5'TI COX2-b & $\begin{array}{l}\text { CTAGGCATTTTAATAAATCTTAACCTTTAGACTCTTTTGT } \\
\text { CTATTTATAATATGTTAATACTATTACGCCATGGTCAGCT } \\
\text { TACGCCCGCCTGTTTGGCGGGCGTAAGCTGG }\end{array}$ \\
\hline
\end{tabular}

Colour legend:

Purple $=$ Xbal overhang

Blue = hairpin loop

Green highlights - Kozak sequence
Pink $=$ stop codon

Yellow highlights $=\mathrm{mt}$ translation initiator

$\underline{\text { Red underline }=\text { translation initiation signal }}$

$\operatorname{Red}=\operatorname{COX} 2$ gene sequence 
The 5'TI COX2-a primer was diluted with $150 \mu \mathrm{L}$ of MQ $\mathrm{H}_{2} \mathrm{O}$, and 5'TI COX2-b was diluted with $162 \mu \mathrm{L}$ of MQ $\mathrm{H}_{2} \mathrm{O}$ to make a stock solution concentration of $1 \mu \mathrm{g} / \mu \mathrm{L}$. Then, $40 \mu \mathrm{L}$ of both primers where combined with $25 \mu \mathrm{L}$ of T4 DNA ligation buffer. This mix was placed in a heat bath at $98^{\circ} \mathrm{C}$ for 3 minutes. Samples were then left to cool down slowly in a styrofoam box for 3 hours, while uncovering the lid every $30 \mathrm{~min}$. to expedite the cooling process. After they cooled to $\sim 30^{\circ} \mathrm{C}$, they were heated again to $55^{\circ} \mathrm{C}$ and then allowed to cool down before they were stored at $-20^{\circ} \mathrm{C}$. This procedure was repeated to make a mutated version of this primer; $5^{\prime}-$ $\operatorname{cox} 2-109$.

Recombinant p416 carrying the cloned 3'-UTR of yeast $O X A 1$ gene was then digested with $\mathrm{XbaI}$ for 5 hours at $37^{\circ} \mathrm{C}$. Next, the digest was visualized with $1 \%$ agarose gel. Digested plasmids were purified via QIAquick plasmid purification kit. The purified plasmids were ligated with the double-stranded $5^{\prime}$ primer overnight at $16^{\circ} \mathrm{C}$ water bath. After that, candidates were digested again with $\mathrm{XbaI}$ for $2 \mathrm{hrs}$ at $37^{\circ} \mathrm{C}$ in order to eliminate background plasmids (those without the insert). Plasmids form the obtained clones were subjected to a two separate restriction digestion reactions with $S t y I$ and $B g l I$ to further confirm the presence of inserts. Digested DNA fragments were then visualized on $1 \%$ agarose gel.

Finally, two purified clones were sent for sequencing at the Ottawa General Hospital. Consequently, Basic Local Alignment Search Tool (BLAST) was used to search for sequences of the cloned 3' and 5' inserts. This confirmed that our plasmid construction was a success.

To make a control construct carrying 5' -UTR only, the recombinant $\mathrm{p} 416$ above was digested with BamHI to cut the 3'-UTR insert out of the plasmid, and relegated to itself leaving the plasmid with 5 ' insert only. 
Chapter 3: Results 


\section{CHAPTER 3: RESULTS}

\subsection{Study design}

mRNA sorting to the vicinity of $\mathrm{mt}$ seems to be critical for the activity of this organelle. It has been previously shown that the 3'-UTR of yeast $O X A 1$ mRNA is necessary for the localization of this mRNA to the vicinity of mt. However, due to the limitation of the localization techniques used in such studies, it is not clear whether the mRNA enters the mt or simply attaches to the outside of the mt (Corral-Debrinski et al., 2000). Translation in mt seems to be mediated by a conserved sequence. It has been reported that mt ribosomes recognize a common feature to all yeast mt mRNA 5'-UTR, which is a highly conserved octanucleotide sequence 5'-UAUAAAUA-3'. The 5'-UTR of yeast COX2 mt mRNA was found to be essential for the translation of this gene inside the $\mathrm{mt}$. When $C O X 2$ was mutated, the translation activity in mt was eliminated (Mulero and Fox, 1993).

Here, we tested the ability of yeast $O X A 1$ 3'-UTR to target a mRNA to yeast mt. To do so, we designed a chimeric mRNA, in vitro, using lac $Z$ gene. First, we placed yeast $C O X 2$ 5'UTR in front, as well as yeast $O X A 13^{\prime}$-UTR at the 3' end of a lacZ mRNA on an expression plasmid. Then, we transformed yeast cells with the designed construct and observed its expression.

\subsubsection{Designing and Cloning 3'-UTR}

Mt translation machinery theory was used to investigate the import of the customized mRNA into yeast mt. The first phase of this project was completed by cloning yeast $O X A 13^{\prime}-$ UTR at the 3 '-end of lacZ gene in p416 (Figure 3.1). 


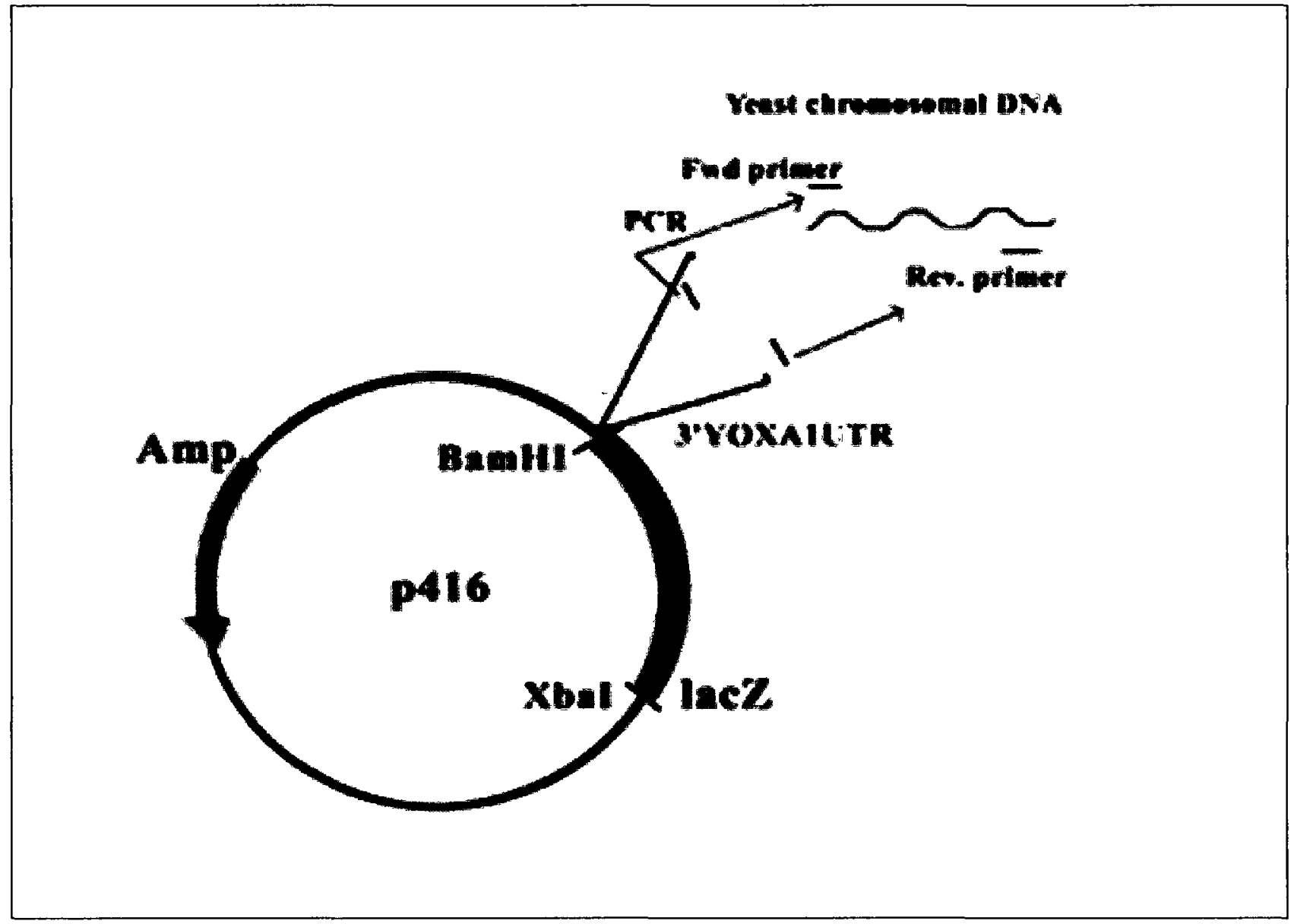

Figure 3.1: Constructed vector $\mathrm{p} 416$ containing an Ampicillin resistant gene, a lacZ reporter gene, and the inserted PCR product yeast $O X A 13^{\prime}$ '-UTR. The plasmid was $\sim 5.5 \mathrm{~kb}$ in size and also included a galactokinase promoter upstream of lacZ gene. 
Ribosomes are non-membranous organelles that are either found suspended freely in the cytosol, or bound to the rough endoplasmic reticulum in eukaryotes. Polysomes, also referred to as ribopolysomes, are clusters of ribosomes bound to the surface of mt (Alberts et al., 2002).

Previous studies showed that some mRNAs are localized to the vicinity of $\mathrm{mt}$, and that ribopolysomes may contribute to the import of proteins into mt (Margeot et al., 2005). It is believed that the 3'-UTR of certain mRNAs plays a role in directing the gene towards the mt. Yeast $O X A 1 \mathrm{mRNA}$ gene codes for cytochrome $c$ oxidase assembly protein, and is found in prokaryotes and eukaryotes. A study that induced a mutation in the 3'-UTR (158bp) (Table 3.1) of yeast $O X A I$ showed a complete respiratory deficiency in $\mathrm{mt}$. It was suggested that $O X A I \mathrm{did}$ not get translated nearby the $\mathrm{mt}$ because the sequence that was thought to lead it there was altered (Sylvestre et al., 2003a) and hence unable to localize the mRNA.

We hypothesized the 3'-UTR of OXA1 may in fact lead the mRNAs inside mt. Therefore, we cloned the 3'-UTR of this gene into our plasmid p416. We amplified the target sequence using PCR and yeast total genomic DNA as a template. Figure 3.1 shows the result of the amplification of the target region. We introduced BamH1 restriction site into the amplifying primers and used this sequence to digest the PCR product. We digested p416 using BamH1 which cuts the plasmid at a unique site at the 3' end of $L a c Z$ gene. We then re-ligated the plasmid in the presence of 1000 fold excess digested insert. After transformation of $E$ coli with the ligation mixture, we screened more than 25 clones for the presence of insert into $\mathrm{p} 416$ plasmid. 
Table 3.1: Sequence of yeast $O X A 13^{\prime}$ 'UTR that was inserted into the plasmid.

\begin{tabular}{|l|l|}
\hline \multirow{2}{*}{$O X A 1$} & \multicolumn{1}{c|}{ Sequence $(5, \rightarrow 3)$} \\
\hline $\begin{array}{l}\text { AAAAAATGAATAAAGGCTCTATATCTCTCTGTAAATATAAAAATAT } \\
\text { AAAACAACCCTCGATAGGCGGGACCAAATTTTCTCTCTCAG } \\
\text { CAGTGGATGTATACATTTACCACGAAAATTGTTTATTGCTTGAAAT } \\
\text { AATCATTTGGATTCTTAAT }\end{array}$ \\
\hline
\end{tabular}


Figure 3.2 shows an image from the agarose gel of the digested constructs by BamH1. It clearly indicates that the PCR product was cloned into the expression vector (L3 and L5). The observed $10 \mathrm{~kb}$ band corresponds to the size of the intact $\mathrm{p} 416$. In L4 no band was released suggesting that the plasmid did not contain an insert (background plasmid used as a control). The released lighter band that appears 158nt in size corresponds to an insert (red arrows in Figure 3.2).

To further confirm the presence of an insert into these vectors, potential recombinant plasmids were digested with ClaI. This enzyme has a restriction site on the vector p416 shortly downstream from the BamHI site, and on the lacZ itself. The presence of an insert would make one of the bands, released by ClaI, heavier than the one in the background (p416) (Figure 3.3: L2, L4). This was indeed observed in the gel (Figure 3.3: L3, L5). In Figure 3.3, L3 and L5 indicate the presence on an insert (see red arrows) into the vector (L2 and L4).

To confirm the presence of the insert and the successful cloning of the target DNA we sequenced the candidate plasmids. The sequencing results confirmed the presence of the insert in the correct orientation. 


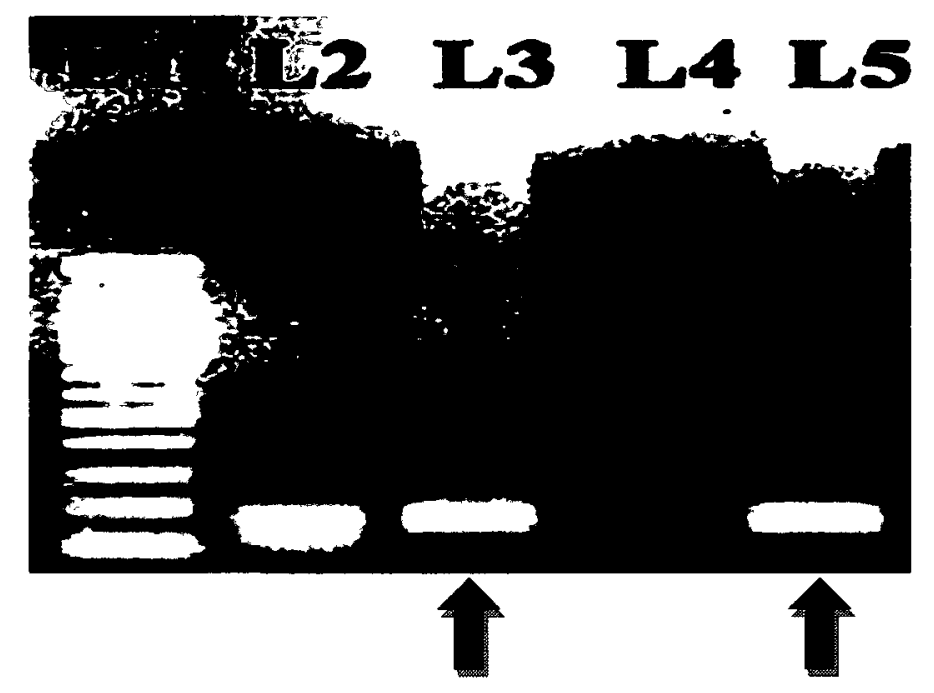

Figure 3.2: Agarose gel of purified recombinant 416 digested with BamHI, compared to a 100bp DNA ladder (L1), PCR product (L2), and purified intact p416 digested with BamHI (L4). The lighter bands represent the cloned inserts (L3, L5) (red arrows). There was no sample in (L4). 


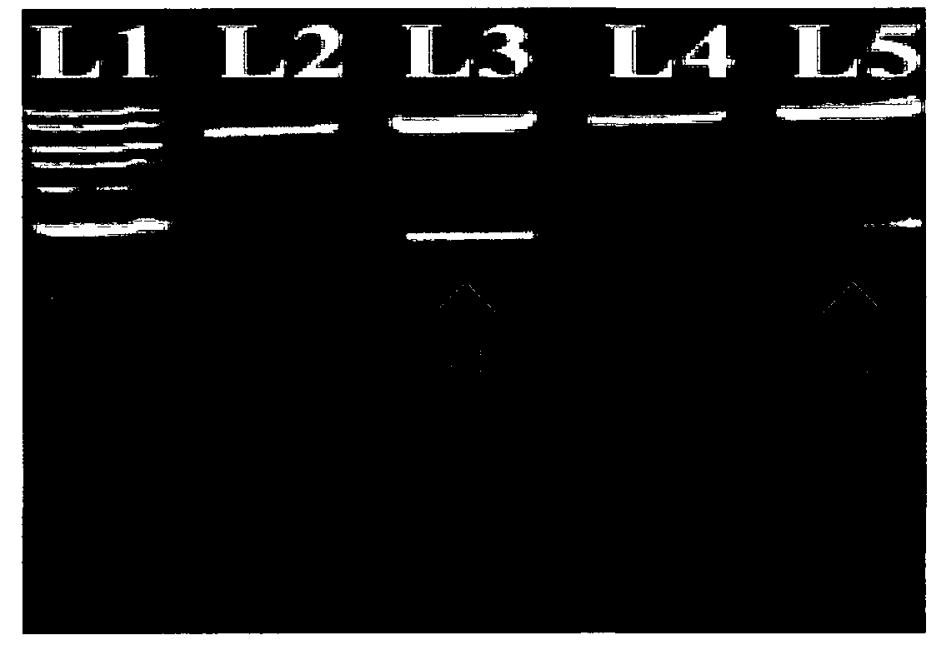

Figure 3.3: Agarose gel of purified recombinant $\mathrm{p} 416$ digested with ClaI, compared to a $1 \mathrm{~Kb}$ DNA ladder (L1), and purified intact p416 digested with $\operatorname{ClaI}$ (L2, L4). The heavier released bands indicate the presence of an insert (L3, L5 - red arrows). 


\subsubsection{Designing and Cloning 5'-UTR}

Three different constructs were designed as in Table 3.2 and Figure 3.4. In these constructs, a strong inhibitory hairpin structure is designed to prevent translation of the mRNA by cytoplasmic ribosome (Kozak, 1989a).

It has been shown that a strong stem-loop structure, located on the mRNA between its 5'end and the first AUG, prevents the ribosome from scanning the mRNA. Instead, the ribosome ends up stalling at the 5'-end of the structure (Kozak, 1989a). Therefore, if our designed mRNA, which is targeted towards yeast mt, binds to cytoplasmic ribosomes, it should not be translated there. We believe that these ribosomes will not be able to scan the hairpin on the mRNA. The sequence of this hairpin (35bp) was chosen from a study by Vega Laso et al. (1993), who demonstrated the effectiveness of this hairpin at preventing the advancement of the $40 \mathrm{~S}$ ribosomal subunit along the mRNA strand (Vega Laso et al., 1993). 
Table 3.2: Sequences used in the 3 designed constructs.

\begin{tabular}{|l|l|}
\hline & \multicolumn{1}{|c|}{ Sequence $\left(5^{\prime} \rightarrow 3\right)$} \\
\hline Hairpin & CAGCTTACGCCCGCCAAACAGGCGGGCGTAAGCTG \\
\hline COX2 gene & $\begin{array}{l}\text { AGTATTAACATATTATAAATAGACAAAAGAGTCTAAAGGTTAA } \\
\text { GATTTATTAAA }\end{array}$ \\
\hline cox2-107 & $\begin{array}{l}\text { AGTATTAAagatcTtaAAATAGACAAAAGAGTCTAAAGGTTAAGA } \\
\text { TTTATTAAA }\end{array}$ \\
\hline$X b a I$ & TCTAGA \\
\hline
\end{tabular}




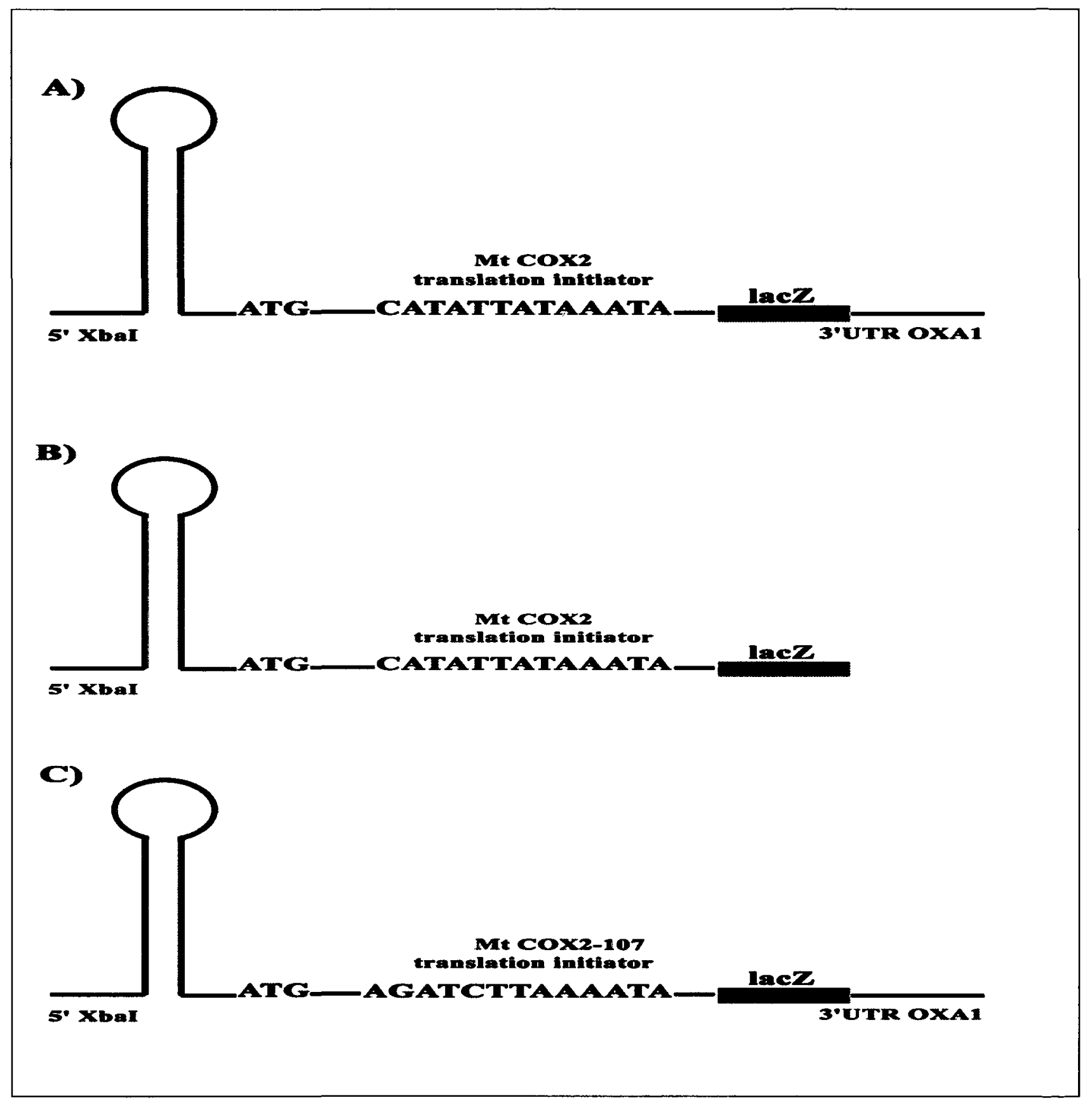

Figure 3.4: The designed constructs. (A) construct showing yeast 5'-UTR COX2 attached to lacZ gene, with a hairpin loop, and 3'-UTR OXA1 (B) construct including yeast 5'-UTR COX2 attached to lac $Z$ gene, with a hairpin loop (C) construct containing yeast non-functional mutant 5'-UTR cox2-107 attached to lacZ gene, with a hairpin loop, and 3'-UTR OXA1. (not to scale) 
If a ribosome manages to pass through the inhibitory hairpin structure above, then in theory it can produce $\beta$-gal within the cytoplasm of the cell and hence complicate our results. To prevent this from happening, a secondary measure was taken that includes a premature out-offrame initiation codon with a corresponding stop codon. It has been previously shown that a consensus sequence ACCAUGG, referred to as Kozak sequence, plays a major role in translation initiation in eukaryotes as it mediates the selection of the start codon AUG. (Kozak, 1984). Therefore, we placed an out-of-frame start codon, ATG, which is a part of the Kozak sequence, next to the hairpin structure (Figure 3.4). It is believed that this ATG has an inhibitory effect for the cytoplasmic translation of $\beta$-gal since it blocks the initiation of the gene from a downstream site. According to the scanning model, if an upstream AUG codon is placed in the wrong reading frame, then the translation of the downstream gene should be suppressed (Kozak, $1989 \mathrm{~b}$ ), in this case the $L a c Z$ gene. We also placed an out-of-frame stop codon, TAA, a few nucleotides after the Kozak sequence as another secondary measure to ensure that the mRNA does not get translated in the cytoplasm. As a result, we have created optimal conditions, which include a consensus sequence, to ensure that the escaped cytoplasmic ribosomes are recruited to the out-of-frame start codon ATG rather than the actual $\operatorname{COX} 2$ translation initiation site, which was inserted after TAA.

The third feature of this construct is the inclusion of a sequence that can mediate mt translation. As mentioned above, the 5'-UTR of yeast mt mRNA seems to be important for the translation of the gene. Evidence showed that there is a specific sequence found in the 5'-UTR of all yeast mt mRNAs. This consensus sequence (5'-UAUAAAUA-3') (see underlined sequence in table 3.2) allows the ribosomes located inside the mt to recognize the mRNA and initiate translation (Green-Willms et al., 1998). There are 8 major mt mRNAs with different 
characteristics such as: sequence, complexity and length. We chose the mt mRNA, COX2, because it has the shortest 5'-UTR sequence (54bp) (Table 3.2). COX2 codes for cytochrome $c$ oxidase subunit II, the terminal member of mt inner membrane electron transport chain (Bonnefoy et al., 2001). A study compared the effects of $C O X 2$ and several mutant forms of the gene on mt translation initiation. They found that a mutation in the 5'-UTR of the gene causes significant decrease in mRNA levels in the mt. We chose the mutant cox2-107, which had 6 altered nucleotides in its interior section (see bold small-cap letters in table 3.2), as a control (Dunstan et al., 1997). Hence three different constructs were designed.

A fourth feature of the designed constructs was the inclusion of a modified $\mathrm{XbaI}$ overhang (Table 3.2) in order to ligate the 5'-UTR with plasmid p416, which has a restriction site for this enzyme at the 5'-end of lacZ (Figure 3.4). This overhang was designed in a way that would eliminate $X b a I$ site after insertion into the plasmid. This allowed for the inclusion of an additional selection phase in the experiment simplifying the cloning step for making these constructs. If 5'-UTR was successfully inserted into the plasmid, then a second round of XbaI digestion would eliminate the plasmids that were not recombinant and did not contain the insert.

In Figure 3.4A, the first construct also contained the 3'-UTR of $O X A 1$ gene, which is believed to lead the mRNA towards mt, and the 5'-UTR COX2 gene, which is believed to contain the mt translation initiator. If this construct successfully entered the mt, then a translation product should be detectable. The second construct (Figure 3.4B), contained the 5'UTR, but lacked the 3'-UTR. Thus, we do not expect to detect translation product out of this construct, since it has no sequence to lead the construct towards the mt. The third construct (Figure 3.4C), contained the 5'-UTR of $\operatorname{cox} 2-107$, which is mutational translation initiator, and 
the 3'-UTR. Therefore, even if the 3'-UTR leads the mRNA towards mt, we should not detect any translation product because the 5'-UTR translation initiator was altered.

Restriction enzyme analysis of the designed constructs indicated that they contain a $B g l I$ restriction enzyme site and therefore restriction digestion would allow verification of these constructs. Therefore, to screen for recombinant plasmids, candidate constructs were subjected to restriction digestion independently with $X b a I$ and $B g l I$. Images from the agarose gels indicate the identification of recombinant plasmids. Figure 3.5 shows $X b a I$ digestion of samples. The recombinant candidate (L1 - red arrow) represents a pattern consistent with intact plasmids indicating the absence of a restriction site. The control digested plasmid p416 (L2) on the other hand had a pattern consistent with a single cut in plasmid. Similar differences between digestion patterns were observed in Figure 3.6, where samples were subjected to BglI digestion. The control digested plasmid (L1) was cut into 4 bands (red arrow) whereas the recombinant one (L2) was cut into 5 bands. Most notably, the control plasmid contained a thick band $\sim 2.2 \mathrm{~kb}$ in size (L1), while that of the recombinant plasmid was split into two bands $\sim 2.1 \mathrm{~kb}$ and $\sim 1.9 \mathrm{~kb}$ in size (L2) indicating presence of the target insert. The rest of the bands were comparable between the two samples. 


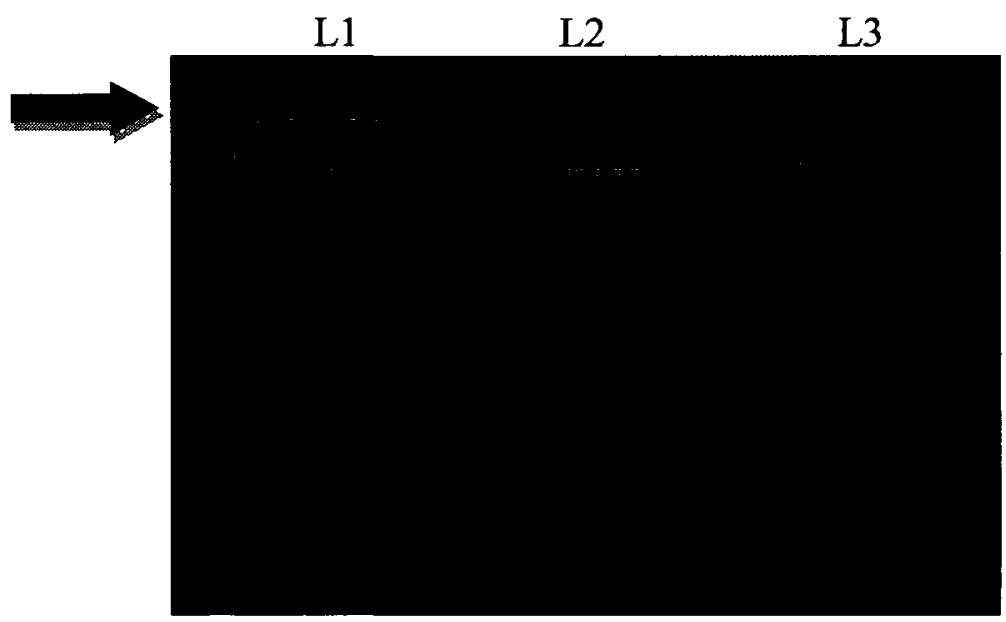

Figure 3.5: Agarose gel electrophoresis of purified samples digested with $X b a I$ showing recombinant p416 candidate (L1), and digested p416 (L2), compared to 1kb DNA ladder (L3). The indigestibility of plasmid in L1 (red arrow) indicates an insertion where $X b a l$ site is destroyed (L1). 


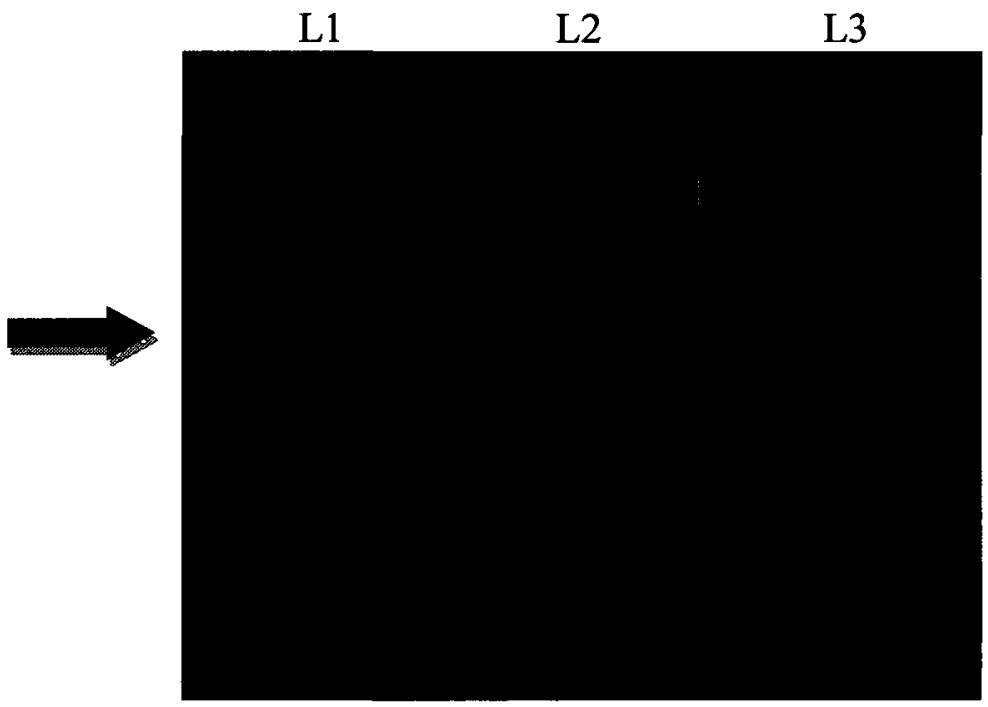

Figure 3.6: Agarose gel electrophoresis of purified samples digested with $B g l I$ showing digested p416 (L1), and recombinant p416 candidate (L2), compared to $1 \mathrm{~kb}$ DNA ladder (L3). There is an expected difference in the third band cleavage in L1 and L2 (red arrow), suggesting the presence of an additional Bgll site, where the enzyme cleaved the candidate sample (L2). 
To confirm the presence of the insert and the successful cloning of the target DNA we sequenced the candidate plasmids. The sequencing results confirmed the presence of the insert in the correct orientation.

\section{$3.2 \beta$-galactosidase assay}

To test the import of the designed mRNA into $\mathrm{mt}, \beta$-gal assay was performed in yeast cells transformed with different constructs. Yeast cells transformed with intact plasmid p416 were used as a positive control.

In theory, we may expect that the first construct, which contained 3'-UTR only, should be directed into the mt. But it may or may not be able to produce any active $\beta$-gal detected by a change of colour. The second construct, containing both 3'- and 5'-UTR should be able to enter the $\mathrm{mt}$ and the outcome of the translation should be detected by a change of colour. In the event that our mRNA was imported into mt and was translated there, if the translation occurred with a low efficiency, then detecting the outcome might be difficult. The third construct contained the 5'-UTR only, thus, we should not detect any outcome of the translation, since there was no sequence that would lead the construct towards the mt. Contrary to the theory, our results showed a slight change of colour in all three constructs. This prompted us to isolate the $\mathrm{mt}$ from yeast and perform $\beta$-gal assay directly on them, to see if we obtain more accurate results.

Indeed, the results were more promising (Figure 3.7). Analyzing the measured optical densities of three constructs showed the 3 ' and 5' construct had the highest $\beta$-gal activity amongst the rest $(600 \%)$. These observations are in agreement with the hypothesis that 3 '-UTR is mediating the entry of mRNA into $\mathrm{mt}$. Interestingly, the $\beta$-gal activity of the 5 ' construct was slightly higher than that of the $3^{\prime}$ construct ( $100 \%$ and $70 \%$, respectively), (Figure 3.7 ). This finding might indicate that some cytoplasmic $\beta$-gal activity is still present in our samples. 


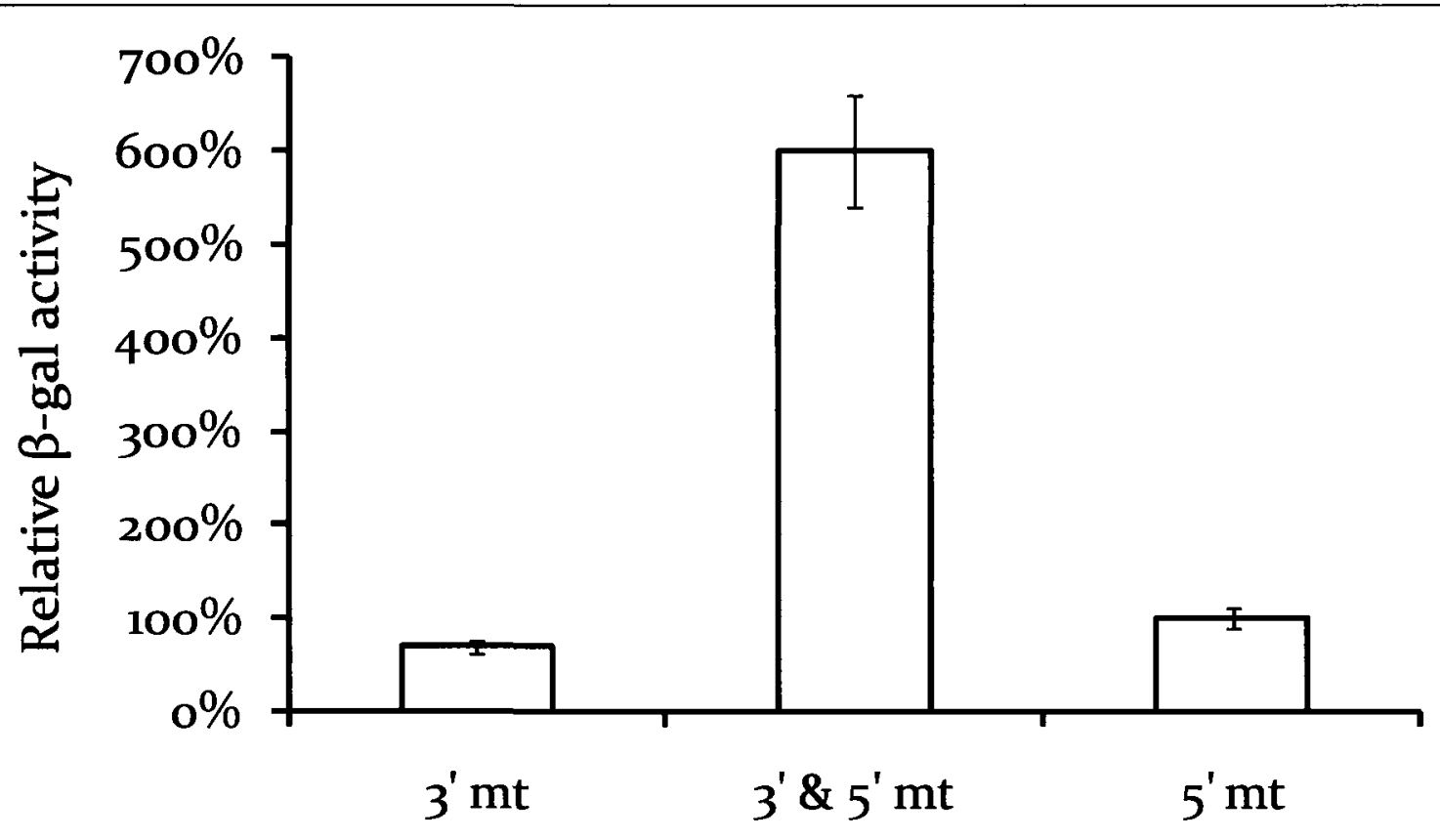

Figure 3.7: Average $\beta$-galactosidase ( $\beta$-gal) activity for yeast $\mathrm{mt}$ isolated from the three constructs. Each experiment was repeated at least three times. The $3^{\prime}$ and $5^{\prime}$ construct ( $3^{\prime} \&$ 5'mt) had the highest $\beta$-gal activity amongst the rest $(600 \%)$. Whereas, the $5^{\prime}$ construct (5'mt) showed slightly higher $\beta$-gal activity than that of the $3^{\prime}$ construct ( $\left.3^{\prime} \mathrm{mt}\right)(100 \%$ and $70 \%$, respectively). 
In order to investigate further the findings obtained from the $\beta$-gal assays, we performed western blots on the isolated $\mathrm{mt}$ as a means for detecting any $\beta$-gal signals that might be emitted from the mt.

Mt were isolated from each yeast cell containing a different construct. Figure 3.8 shows the Protein Standard Marker (L1), as well as a clear band ( 130kDa) for two samples, containing 3'and 5' construct (L2), and 5' only construct (L3). This band is the same size as $\beta$-gal protein (red arrow), which means that some $\beta$-gal is present in the isolated yeast mt samples.

The presence of a $\beta$-gal protein in L3 indicates that some cytoplasmic $\beta$-gal translation is present in our samples despite different measures that we have taken. This may stem from cytoplasmic $\beta$-gal proteins that are co-purified with $\mathrm{mt}$. This is also in agreement with the observed $\beta$-gal activity for 5' construct (Figure 3.7). 


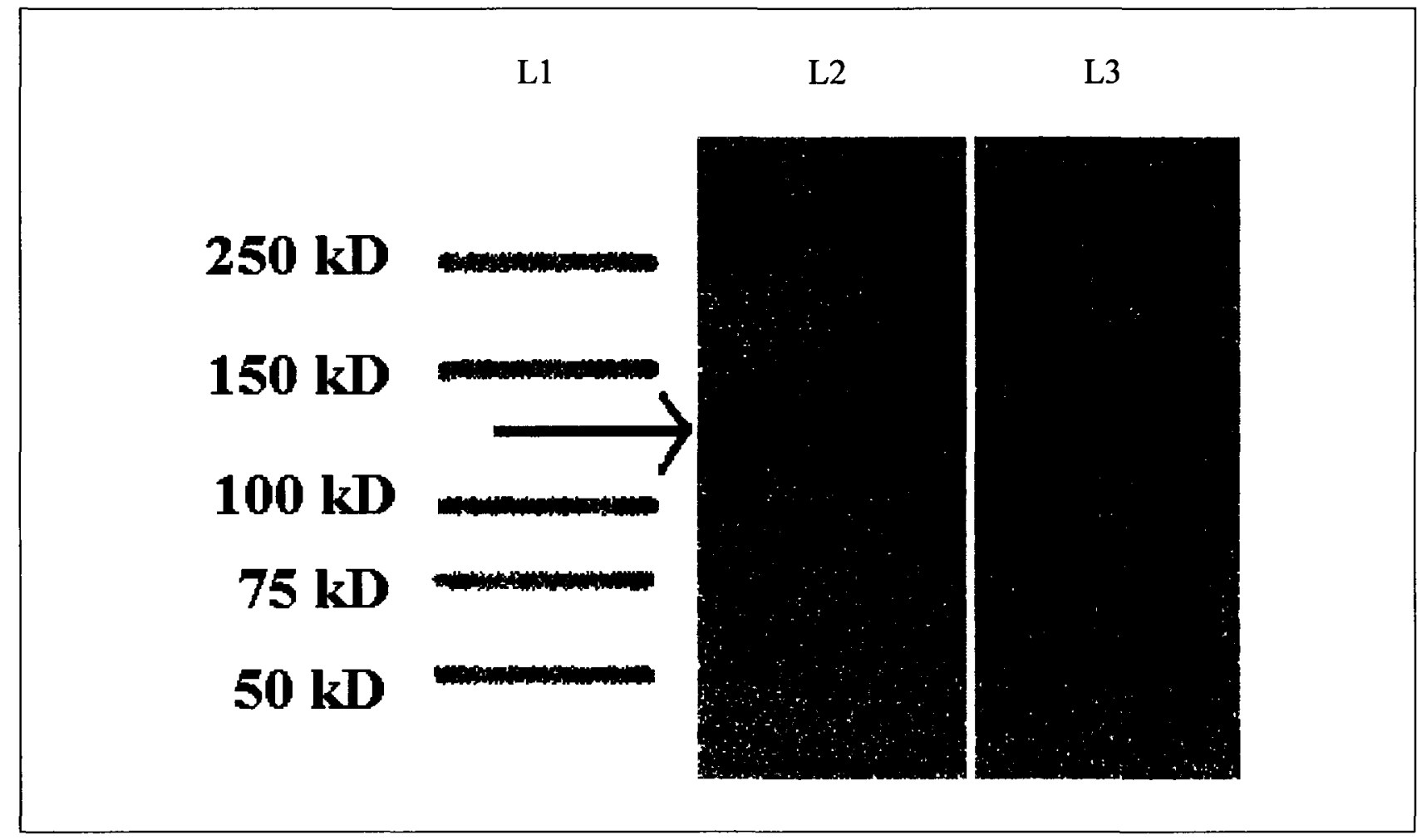

Figure 3.8: Western blot analysis of 2 samples of isolated yeast mitochondria $(\mathrm{mt})$; showing the Precision Plus Protein Kaleidoscope Standard Marker from Bio-Rad (L1), 3' and 5' construct (L2) and 5' only construct (L3). The protein bands match the size of $\beta$-gal protein band (red arrow in $\mathrm{L} 3)(\sim 130 \mathrm{kD})$ suggesting the presence of $\beta$-gal protein in the samples. The band in $\mathrm{L} 2$ is thicker than that in L3. Equal amounts of total proteins isolated from $\mathrm{mt}$ were loaded on different samples. 
If our target mRNAs are in fact directed into $\mathrm{mt}$, we expect to detect them in purified $\mathrm{mt}$. To detect $\beta$-gal mRNA signals in isolated mt, RT-PCR was performed. Detection of a $\beta$-gal activity signal may indicate that our designed mRNA was incorporated into $\mathrm{mt}$ and provides further support that the $\beta$-gal observed was likely produced there. First, total mt RNA was isolated using phenol-chloroform extraction method from purified mt. Isolated mRNA was used to create cDNA copies to be used in real-time PCR. Quantification of RNA was achieved by comparing the threshold cycle $\left(C_{t}\right)$ values of cDNA samples from isolated mt. A wild-type (WT) standard RNA (YPL009C gene) was used as a control as it shows equal levels of expression across a range of different conditions. The average $C_{\mathrm{t}}$ value for mt carrying the 3' and 5' construct was 20.45 (Figure 3.9a). This is in comparison to the $C_{\mathrm{t}}$ value of 23.82 for mt carrying the 5' alone construct. The relative abundance of $\beta$-gal mRNA was approximately 10 fold higher for 3' and 5' construct (Figure 3.9b). RT-PCR was only repeated twice, therefore, these results are not statistically significant. The experiments need to be repeated before taking the results into consideration. However, in both trials, the trend was the same in that the gene expression for the 3' and 5' construct was higher than that of 5' only construct. This possibly will further support the notion that the 3'-UTR of OXAl may mediate the import of mRNAs into mt. 
(a)

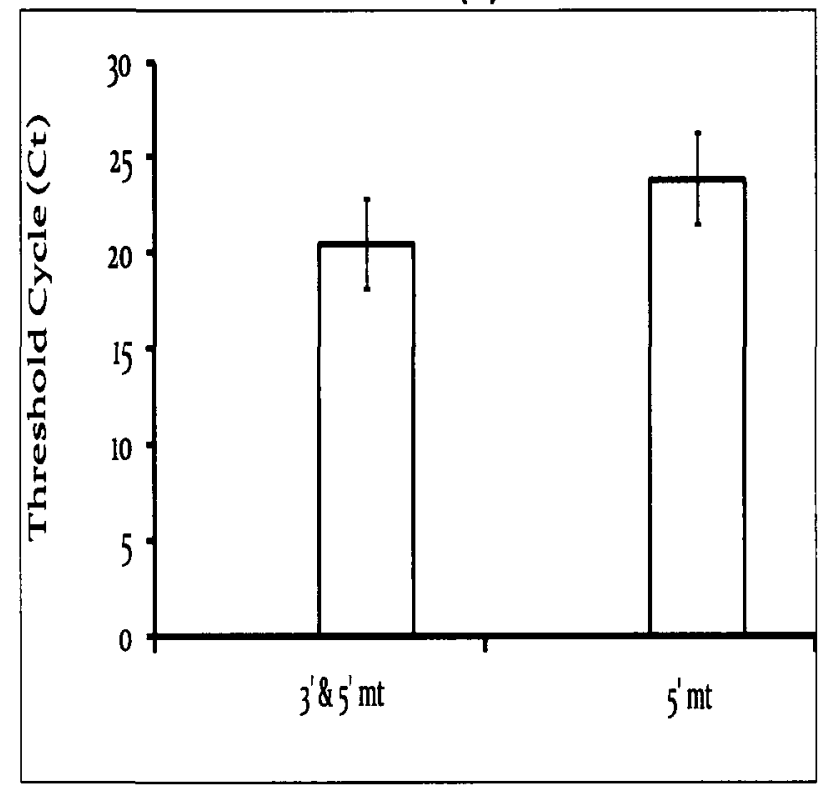

(b)

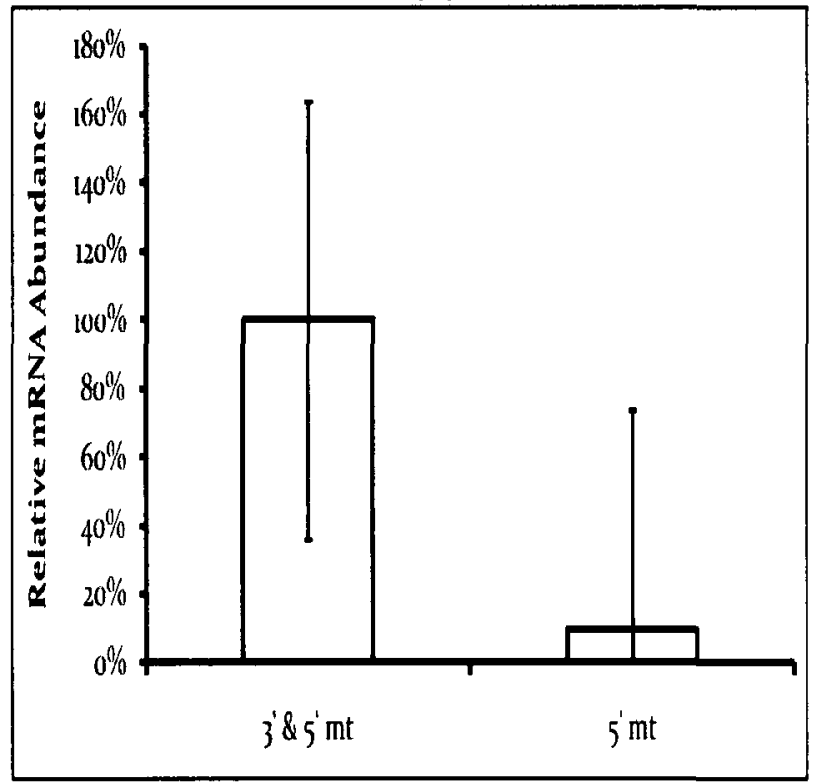

Figure 3.9: Quantitative RT-PCR analysis of RNA isolated from mitochondria (mt) samples.

(a) The threshold cycle $\left(C_{t}\right)$ values for the samples were calculated from the threshold cycles.

(b) The relative $\beta$-gal mRNA abundance of mt containing $3^{\prime}$ and 5 ' construct was set to $100 \%$ for ease of comparison. $\beta$-gal mRNA abundance of mt containing 5 ' construct was $10 \mathrm{X}$ lower than that of the 3' and 5' construct. 
To prepare more $\mathrm{mt}$ with greater purity and with less potential contamination from cytosolic proteins, we used free flow electrophoresis (FFE) to fractionate purified $\mathrm{mt}$. FFE fractionation was followed by absorbance measurements using a microplate reader: Figure 3.10 shows the profile of isolated mt after zone electrophoresis fractionation using FFE system, performed by Zischka et al. (2003). This is the theoretical graph, which suggests that the outcome of the FFE analysis should result in one high peak around fraction \#41 that indicates the location of the highest purified $\mathrm{mt}$ fraction.

Figure 3.11 shows the graph of the 96 fractions collected from the purification of our $\mathrm{mt}$ containing $3^{\prime}$ and 5' construct. Mt were separated by charge to mass ratio of the analytes in the sample, hence, the process is referred to as zone electrophoresis. Of the 96 samples, the most enriched fraction is that of fraction \#45, (it has the highest peak with $\mathrm{OD}_{420} 0.32$ ). This peak is comparable with that of the theoretical one that indicates high $\mathrm{mt}$ purity (Figure 3.10). 


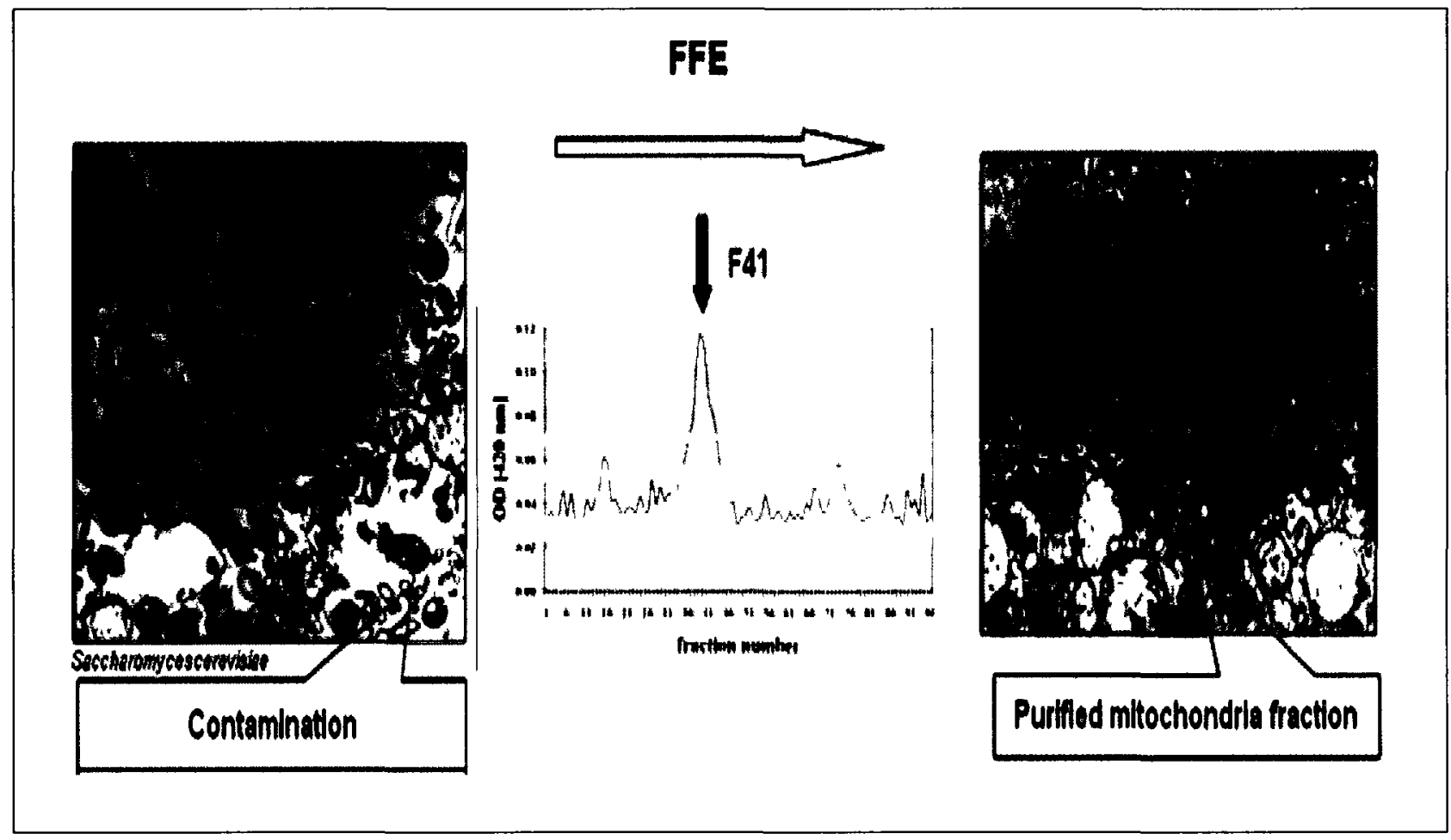

Figure 3.10: Profile of isolated mitochondria (mt) after zone electrophoresis fractionation using BD Free Flow Electrophoresis (FFE) system, performed by Zischka et al. (2003). The graph showed a clear high peak at fraction\#41, indicating presence of the most purified $\mathrm{mt}$ in that sample. Zischka et al. (2003) also show images of yeast mt to demonstrate the accuracy of FFE system in purifying $\mathrm{mt}$. The image on the left shows $\mathrm{mt}$ surrounded by contaminants, and after passing the sample through FFE system, mt were shown stacked side by side with minimum contaminants (image on the right) (Zischka et al., 2003). 


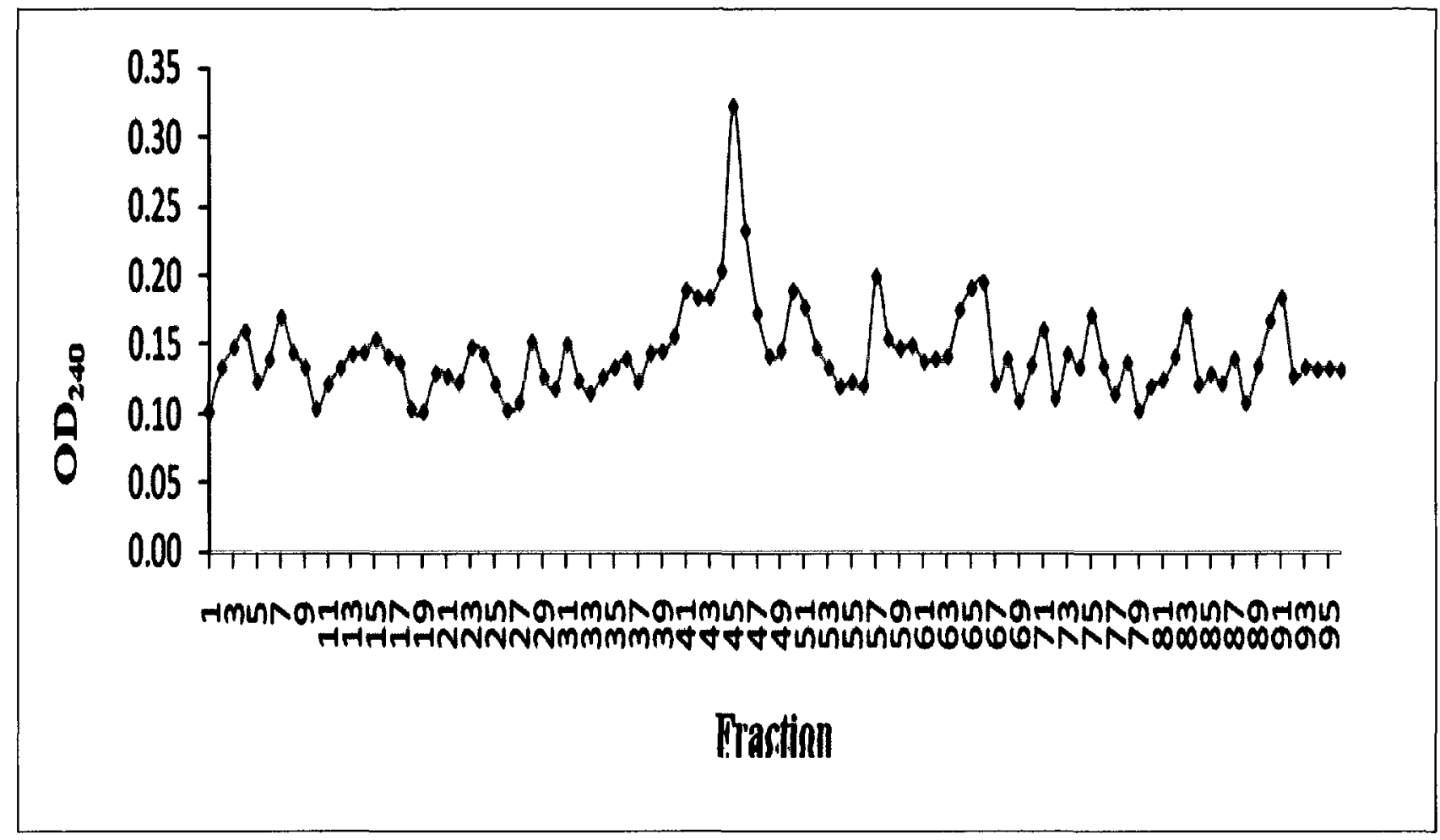

Figure 3.11: Purification of isolated mitochondria (mt), containing our $3^{\prime}$ and $5^{\prime}$ construct, after zone electrophoresis fractionation using BD Free Flow Electrophoresis (FFE) system. The profile showed a similar pattern of mt purification as in the previous graph. The highest peak showing at fraction \#45 suggests mt sample of the highest purity $\left(\mathrm{OD}_{420}=0.32\right)$. 
Chapter 4: Discussion 


\section{CHAPTER 4: DISCUSSION}

Mt are essential organelles found in most eukaryotic cells. They are thought to be direct descendants of prokaryotes. Hence, $\mathrm{mt}$ have retained their own genetic machinery; a characteristic that makes them exceptional (Solomon et al., 1999).

Mt has been the focus of research and media lately because of their link to major health issues such as neurodegenerative diseases and diabetes ( $\mathrm{Du}$ and Yan, 2010).

OXPHOS is a metabolic pathway in $\mathrm{mt}$ that uses energy released by the oxidation of nutrients to produce a useful form of energy; ATP. During OXPHOS, glucose from nutrients is broken down and electrons released are passed around in a series of redox reactions to a final acceptor molecule; oxygen (Mazat et al., 2010). These redox reactions release energy, which is used to form ATP. In eukaryotes, redox reactions are carried out by a series of linked protein complexes within mt, which make up the ETC. However, in prokaryotes, these protein complexes are located in the cytosol (Parikh, 2010). Any disruption in one of the steps of this complex chain reaction will affect its outcome, which is the release of energy. Such disruption is due to genetic mutations and has been linked to a number of pathologies observed such as cellular respiration defects. These defects can also result in severe and often fatal metabolic disorders that affect tissues with high energy demands like the brain, heart, or muscle (DiMauro et al., 1998).

Similarly defects in $\mathrm{mt}$ are known to affect apoptosis. Apoptosis is the natural programmed cell death that takes place at the end of a life cycle of a cell. A malfunction in its mechanism results in an uncontrolled cell proliferation, which causes a series of serious health issues (Karbowski, 2010). This malfunction is caused by genetic mutations in mt genes that are responsible for apoptosis. Mutations in $\mathrm{mt}$ genes in humans have been linked to 
neurodegenerative diseases. Recent studies have also implicated abnormal mt function in the pathogenesis of Parkinson's and Alzheimer's diseases. These studies establish mt dynamics as a new paradigm for neurodegenerative disease research (Navarro and Boveris, 2010).

There is no effective treatment for $\mathrm{mt}$ disorders. However, gene therapy is currently being explored as a mean to effectively correct $\mathrm{mt}$ defects. Studies showed promising developments in such treatment by selective inhibition of mutant mtDNA, and recombinant mtDNA substitution (Du and Yan, 2010).

In selective inhibition of mutant mtDNA, the idea is to genetically block the replication of mutant mtDNA to reduce the expression of defective proteins. This may be possible by either using DNA, RNA or chemical analogues to bind to cDNA or RNA targets, or restriction enzyme to cut out the mutant part of mtDNA (Bacman et al., 2007).

Another approach is to replace defective mtDNA with healthy ones. A possibility would be to target corrected proteins into mt or alternatively to direct corrected mRNA into mt for translation within this organelle. However, this method is limited due to the lack of availability of human mtDNA vectors, poor mt import of large constructs, the competition of recombinant mtDNA with functional resident mtDNA, as well as lack of proven methods for effectively directing proteins and mRNA molecule to $\mathrm{mt}$ (Chen et al., 2003).

Mt are known to contain their own protein synthesis or translation machinery. Translation is the conversion of genetic information from mRNAs to protein. In general, the overall process is conserved between eukaryotes and prokaryotes, although the eukaryotic process is more complex (Valente and Kinzy, 2003). In eukaryotes, the small (40S) subunit of ribosome binds to the mRNA at its capped 5'-end, and then scans it for the first start codon AUG, where translation is initiated (Nakamoto, 2010). In prokaryotes, the small (30S) subunit 
of ribosome binds to the mRNA at the Shine-Dalgarno site, from which translation is initiated (Nakamoto, 2009).

In $\mathrm{mt}$, translation initiation seems to be based on a sequence signal upstream of the start codon AUG on the mt mRNA resembling prokaryotic translation. However, this signal found on the 5'-UTR of the mRNA is not complementary to the mitoribosome. It is interesting to note that this sequence does not seem to occur at a fixed distance from the start codon of mRNAs. Translational activators encoded by nuclear genes are also required to stimulate the translation of specific mt mRNAs (Chang and Wang, 2004).

Even though $\mathrm{mt}$ has its own translation machinery, only a small number of $\mathrm{mt}$ proteins are encoded inside mt. The rest of the proteins are imported into the mt by complex protein import pathways. Therefore, $\mathrm{mt}$ proteins are generated as precursors, which carry specific targeting signals that direct them towards $\mathrm{mt}$. The biogenesis and function of $\mathrm{mt}$, thus, require coordination and communication between the mt and nuclear genomes (Wiedemann et al., 2004).

It appears that mRNAs encoding $\mathrm{mt}$ proteins are found in the vicinity of $\mathrm{mt}$. Most $\mathrm{mt}$ proteins are encoded in the nucleus; therefore, they need to be imported into mt. Hence, mRNAs found near mt are thought to be involved in facilitating protein transport into mt (Neupert, 1997). Localizing mRNAs is necessary to deliver newly synthesized proteins to their site of action. These mRNAs have a certain sequence in their 3'-UTRs that allows them to be localized around mt. In Chabanon et al (2004) researchers suggest that this sequence in 3'-UTR of mRNAs serve as a binding site for specific RNA-binding proteins that interact with motor proteins that transport mRNA to their destinations within the cytoplasm (Chabanon et al., 2004). An example of such mRNA is yeast $O X A 1$ gene. A complete respiratory deficiency in yeast mt was observed 
when mutating the 3'-UTR of $O X A 1$. This mutation was observed to prevent the mRNA from being sorted near mt (Loya et al., 2008), a condition which was reversed by the human 3'-UTR of $O X A 1$ gene suggesting that the activity of this 3'-UTR is evolutionary conserved between human and yeast.

Furthermore, mitoribosomes seem to recognize a highly conserved octa-nucleotide sequence (5'-UAUAAAUA-3') in the 5'-UTR of mt mRNA. An example of such mt mRNA is yeast mt $\mathrm{COX} 2$ gene, which contains the conserved mitoribosome binding site in its 5'-UTR. Translation activity was absent for $C O X 2$ which had a mutated ribosome binding site (GreenWillms et al., 2001).

Combining the two major aspects of mt localization and translation, we designed a gene composed of lacZ, used as a reporter gene to produces B-gal, the 3'-UTR (158bp) of yeast $O X A 1$, and the 5'-UTR of yeast $\operatorname{COX2}$ (54bp). To prevent translation of the designed mRNA in the cytoplasm, we added an inhibitory "hairpin" loop structure between the 5'-end and the first ATG of the gene (Vega Laso et al., 1993) and kept the first ATG out-of-frame with the lacZ (see below). If cytoplasmic ribosome binds to the mRNA, then the loop would cause the ribosome to stall at the 5'-end of the gene (Kozak, 1989a). As a secondary measure, in case cytoplasmic ribosomes fail to stall at the loop, an out-of-frame Kozak sequence, which contains ATG, and a stop codon TAA were placed next to the hairpin (Kozak, 1984). This ATG should have an inhibitory effect that would block cytoplasmic translation initiation from a downstream site. According to the scanning model, if an upstream ATG codon is placed in the wrong reading frame, then the translation should be suppressed (Kozak, 1989b). 
The designed mRNA was cloned into $\mathrm{p} 416$ vector and resulting recombinant vector was then introduced into $S$ cerevisiae. We also cloned 3 other constructs; one that carries the 3'UTR but not the 5'-UTR, one that carries the 5'-UTR but not the 3'-UTR, and one that has both UTRs as well as a mutation in the consensus sequence of the 5'-UTR (Figure 3.4).

To check if our designed mRNA was imported into $\mathrm{mt}$, we performed in vivo $\beta$-gal assays on the different cloned yeast candidates, each carrying a different construct, with the exception of the mutational construct, with the exception of the mutational construct for which we did not have time to complete the experiments. Unexpected $\beta$-gal activity was observed for all three constructs. This suggests that even though we have taken several measures to eliminate the production of cytoplasmic $\beta$-gal, some cytoplasmic translation of mRNAs is still taking place. Such cytoplasmic translation could complicate the interpretation of our results as it would compete with mt translation known to be significantly less efficient and abundant.

Therefore, we proceeded with examining translation activity using isolated mt (Figure 3.7). The results showed the $3^{\prime}$ and 5 ' construct had the highest $\beta$-gal activity amongst the rest (600\%). This finding is in agreement with the hypothesis that the 3'-UTR of $O X A 1$ could direct mRNA into $\mathrm{mt}$ and that the 5'-UTR of $\operatorname{COX} 2$ can mediate translation inside mt. Interestingly the $\beta$-gal activity was also found for both the 5 ' construct alone and the 3 'construct alone $(100 \%$ and $70 \%$, respectively) (Figure 3.7 ). This activity might be as a result of background contamination. It remains possible that during the purification of $\mathrm{mt}$, many contaminating proteins get copurified along with mt. These co-purified proteins represent cytoplasmic translations and compete with measurement of $\beta$-gal activity derived from $\mathrm{mt}$.

There are two possible explanations for cytoplasmic translation derived from mRNA with inhibitory structure. First it is possible that ribosomes can bypass all the measures that we have 
taken to prevent translation in cytoplasm. A second possibility is that mRNAs might get partially degraded and it is these degraded mRNAs that get translated. The presence of a site of mRNA cleavage after the inhibitory structure can well explain these observations. Therefore it appears that we may never be able to completely eliminate cytoplasmic translation and consequently our purified $\mathrm{mt}$ might always contain some of these proteins.

To better differentiate between cytoplasmic and $\mathrm{mt}$ translation, one approach might be to maximize the level of mRNA translation inside $\mathrm{mt}$. In this context there are several issues associated with our approach. For example, the hairpin structure used to reduce cytoplasmic translation may have also interfered with $\mathrm{mt}$ translation machinery. This is highly unlikely because $\mathrm{mt}$ are believed to have a prokaryotic origin, thus their translation system should differ from that of the eukaryotic one (Chaciñska and Boguta, 2000). Mt have their own translation mechanism with unique features. Their mRNAs are uncapped, and their 5'-UTR contains AUG sequences upstream of the initiator AUG (Sylvestre et al., 2003a). This means that the scanning model for translation will not work for $\mathrm{mt}$. Therefore, as long as $\mathrm{mt}$ ribosomes recognize the consensus sequence, then an inhibitory stem-loop structure should not interfere with the ribosomes' ability to translate the mRNA.

Another problem is that lacZ gene might not be a good candidate for this kind of experiments; that is, it may not be a good template for optimal $\mathrm{mt}$ translation. The reason why we used this gene is because it is a commonly used reporter gene that codes for $\beta$-gal, whose activity is easily detected (Mumberg et al., 1994). In addition, lacZ is a prokaryotic gene (isolated from E. coli) and this may make it a good candidate to study mt-based translation which resembles that of prokaryotics. $L a c Z$ is not present in the yeast system eliminating possible interference that might hinder the detection of its product (Matsumoto et al., 1988). A major 
issue with $\operatorname{lac} Z$ is that its sequence is relatively lengthy (more than 3000 nucleotides) which may interfere with the entry of its mRNA into mt. Similarly its amino acid content may not be optimized for translation inside $\mathrm{mt}$.

In addition the 3'-UTR used in our study might be specific to certain genes only. In other words, the 3 '-UTR might efficiently work for just yeast $O X A 1$ and $O X A 1$-like genes. A possible explanation is that there may be other sequences within $O X A l$ gene that enhance the activity of this 3'-UTR in mediating mRNA import.

Our attempt to further purify mt using a FFE system was cut short due to time constrains. This system is very promising in isolating organelles to near purify (Zischka et al., 2003).

To complement our observations we then performed western blots using an anti- $\beta$-gal antibody on the isolated $\mathrm{mt}$ in an attempt to detect $\beta$-gal signal. In agreement with our $\beta$-gal activity assay we detected a stronger band for the $3^{\prime}$ and $5^{\prime} \mathrm{mt}$ sample than the one containing 5' only mt (Figure 3.7). The bands matched the size of theoretical $\beta$-gal protein band $(\sim 130 \mathrm{kD})$. To confirm that $\beta$-gal was in fact produced in $\mathrm{mt}$ and was not imported into this organelle, we investigated the presence of $l a c Z \mathrm{mRNA}$ in purified $\mathrm{mt}$ using RT-PCR. In agreement with above observations, we detected significantly more (10 fold) mRNA in the sample containing 3' and 5' $\mathrm{mt}$ than the one containing the 5 ' only $\mathrm{mt}$ (graph not shown).

While our work is the first of its kind to combine the features of 3'and 5'-UTRs in one gene and examine its possible translation activity inside $\mathrm{mt}$, others have explored the possibility of mRNA localization to the vicinity of $\mathrm{mt}$ which is mediated by cytoplasmic translation.

Most mt genes require several translation regulators. These regulators facilitate the cotranslational import of newly synthesized proteins (Bonnefoy and Fox, 2000). Proteins encoded by nuclear genes are first translated on cytoplasmic ribosomes and then are transported into mt. 
However, strong experimental evidence suggested that cytoplasmic ribosomes bound to mt may control a co-translational import process. This process has been studied with microarrays to identify all nuclear-encoded mRNAs co-purified with mt. Results showed about half of mRNAs encoding $\mathrm{mt}$ proteins were found to be translated in the vicinity of the mt (Marc et al., 2002). PUF proteins are a family of translational regulatory proteins that repress the translation of their target mRNAs by binding to elements located in the 3'UTR in eukaryotic species. Puf3p is a member of this family and is localized to the outer $\mathrm{mt}$ surface. Puf3p binds to a consensus motif in the 3'UTR of many mRNAs encoding mt proteins (Wickens et al ,2002).

Saint-Georges et al (2008) explained that asymmetric localization of mRNA plays an important role in coordinating post-transcriptional events in eukaryotic cells. They investigated mt localization of nuclear-encoded mRNAs in various conditions in which the mRNA binding protein context and the translation efficiency were altered. From the 786 nuclear genes coding for mt proteins Saint-Georges and colleagues characterized two classes of mRNAs translated in the vicinity of mt: Class I (256 genes) and class II (224 genes). While, Class III (306 nuclear genes) included mRNAs that are translated on free cytoplasmic polysomes. Class I mRNAs were translated close to the mt and were shown to have a Puf3p binding motif in their 3'UTR. Many of them showed impaired mt localization when PUF3 was deleted. In addition, mutations in the Puf3p binding motif altered mt localization of $B C S 1$ mRNA. Class II mRNAs were found to have no Puf3p binding site and, hence, their asymmetric localization was not affected by the absence of PUF3. Therefore, the researchers were able to show evidence of a connection between Puf3p and the asymmetric localization of Class I mRNAs, and that their translated proteins were subsequently imported into $\mathrm{mt}$ (Saint-Georges $e t$ al , 2008). 
Recently, Eliyahu et al (2010) tested the possible mechanism of mRNA localization to the vicinity of yeast $S$ cerevisiae $\mathrm{mt}$ by studying $\mathrm{mt}$ translocase. Mt translocase is a complex of proteins located in the mt outer membrane (TOM complex) and it controls the import of a large number of nuclear-encoded proteins. Tom 20 is a peripheral component of the TOM complex. To do so, they isolated $\mathrm{mt}$ fractions from yeast cells lacking the major import receptor, Tom 20 , and compared their collected mRNA to that of wild-type cells by DNA microarrays. They were able to show that yeast cells possess an mRNA mt association mode, whereby Tom 20 interacts with the translated mt targeting signal (MTS), and that this interaction might be assisted by Puf $3 p$, an RNA binding protein, presumably through interaction with specific sequences on the 3'-UTR, which leads to mRNA localization (Eliyahu et al., 2010).

In another study, Garcia et al. (2010) studied mt localization using an improved statistical fluorescent in situ hybridization (FISH) technique. They fused $A T P 2$, a gene that controls mRNA asymmetric localization, to lacZ, a reporter gene. They applied five fluorescent probes complementary to $l a c Z$. To visualize the hybrid, they used a three-dimensional (3D) imaging analysis on more than 50 yeast $S$ cerevisiae cells. Researchers were also interested in examining the role of the leading peptide in mRNA localization. They deleted or replaced the coding sequence (MTS) of ATP2-lacZ hybrid. They found that the asymmetric localization of $A T P 2$ mRNA to mt was considerably reduced and that the MTS is necessary for mRNA localization and translation (Garcia et al., 2010). 
In conclusion, to date, no mRNA has ever been shown to be imported into mt. Here we made an attempt to study the possibility of such an import using a mRNA 3 '-UTR signal that is thought to be responsible for localization of mRNA to $\mathrm{mt}$, as well as the principles of translation machinery within mt. Our results are promising and suggest that an import of mRNA into mt may exist. However the problem of contaminating proteins that are co-purified with mt reduces our confidence in our data. For example, it remains possible that $\beta$-gal produced from one of the constructs have a higher affinity for binding to $\mathrm{mt}$ and hence is selectively co-purified with $\mathrm{mt}$. 


\section{Future directions}

In the future we would like to follow up by further purifying mt using a FFE approach. This may help eliminate the presence of cytoplasmic translated B-gal in our purified samples, which can simplify the interpretation of our data. Similarly, use of mild protease that can eliminate cytoplasmic proteins leaving $\mathrm{mt}$ intact may increase the purity of our final isolated $\mathrm{mt}$.

The same approach can be applied to lacZ analysis. Addition of mild RNase before the final step of $\mathrm{mt}$ isolation can reduce the amount of contaminating mRNAs in purified $\mathrm{mt}$ sample.

An interesting follow up analysis would be to examine the $3^{\prime}$ and 5' construct which carries a non-functional translation initiation sequence. We have made this construct but due to time limitation we have not managed to investigate its activity in mt. We expect to see reduced levels of translation mediated by this construct in comparison with the 3' and 5' construct. This can give us further evidence for the presence of $\mathrm{mt}$ translation for our construct.

The experiment could be repeated using a different reporter gene, such as green fluorescent protein $(G F P)$ gene, or chloramphenicol acetyltransferase $(C A T)$ gene, which are smaller in length and therefore might be imported into $\mathrm{mt}$ with better efficiency. This can also help us determine the universal applicability of 3'-UTR of OXA1 in directing mRNAs into mt.

The long term goal is to direct mRNAs into human mt as part of a gene therapeutic treatment. If this type of experiment works, then it may open the door to finding a cure for numerous disorders caused by $\mathrm{mt}$ diseases. If it is successful, gene therapy provides a way to fix a problem at its source. Although it is a promising treatment option for a number of diseases, including Parkinson's and Alzheimer's, the technique remains risky and requires extensive research and studies to make sure that it will be safe and effective. Gene therapy is currently only being tested for the treatment of diseases that have no other cures. 


\section{REFERENCES}

Alamgir, M., Erukova, V., Jessulat, M., Azizi, A., and Golshani, A. (2010). Chemical-genetic profile analysis of five inhibitory compounds in yeast. BMC Chemical Biology 10: 6-20.

Alberts, B., Johnson, A., Lewis, J., Raff, M., Roberts, K., and Walter, P. (2002). How Cells Read the Genome: DNA to Protein. In Molecular Biology of the Cell, $4^{\text {th }}$ ed. New York: Garland Science; Ch. 6.

Bacman, S.R., Williams, S.L., Hernandez, D., and Moraes, C.T. (2007). Modulating mtDNA heteroplasmy by mitochondria-targeted restriction endonucleases in a 'differential multiple cleavage-site' model. Gene therapy 14(18):1309-1318.

Banerjee, R., Starkov, A.A., Beal, M.F., and Thomas, B. (2009). Mitochondrial dysfunction in the limelight of Parkinson's disease pathogenesis. Biochimica et Biophysica Acta 1792: 651-663.

Bauerschmitt, H., Funes, S., and Herrmann, J.M. (2008). Synthesis and Sorting of Mitochondrial Translation Products. Methods in Molecular Biology Membrane Trafficking 457: 95 112.

BD Diagnostics, Pre-analytical Systems. (2007). http://www.bd.com/proteomics.

Becker, D., Krayl, M., and Voos, W. (2008). In vitro analysis of the mitochondrial preprotein import machinery using recombinant precursor polypeptides. Methods in Molecular Biology Membrane Trafficking 457: 59-83.

Becker, W.M., Kleinsmith, L.J., and Hardin, J. (2003). The World of the Cell, $5^{\text {th }}$ ed. Pearson Education, Inc., San Francisco, CA.

Berg, J.M. (2002). Biochemistry, $5^{\text {th }}$ ed. W.H. Freeman and company, New York, USA.

Blackstone, N.W., and Green, D.R. (1999). The evolution of a mechanism of cell suicide. BioEssays 21(1): 84-88.

Bonnefoy, N., Bsat, N., and Fox, T.D. (2001). Mitochondrial translation of Saccharomyces cerevisiae COX2 mRNA is controlled by the nucleotide sequence specifying the preCox2p leader peptide. Molecular and Cellular Biology 21(7): 2359-2372.

Bonnefoy, N., Chalvet, F., Hamel, P., Slonimski, P.P., and Dujardin, G. (1994). OXA1, a Saccharomyces cerevisiae nuclear gene whose sequence is conserved from prokaryotes to eukaryotes controls cytochrome oxidase biogenesis. Journal of Molecular Biology 239: 201-212. 
Bonnefoy, N., and Fox T.D. (2000). In vivo analysis of mutated initiation codons in the mitochondrial COX2 gene of Saccharomyces cerevisiae fused to the reporter gene ARG8m reveals lack of downstream reinitiation. Molecular and General Genetics 262: 1036-1046.

Boone, C., Bussey H., and Andrews, B.J. (2007). Exploring genetic interactions and networks with yeast. Nature Reviews Genetics 8: 437-449.

Bouras, C., Riederer, B.M., Kfvari, E., Hof, P.R., Giannakopoulos, P. (2005). Humoral immunity in brain aging and Alzheimer's disease. Brain Research Reviews 48: 477-487.

Bryant, W.A., Krabben, P., Baganz, F., Zhou, Y., and Ward, J.M. (2009). The Analysis of Multiple Genome Comparisons in Genus Escherichia and Its Application to the Discovery of Uncharacterised Metabolic Genes in Uropathogenic Escherichia coli CFT073. Comparative and Functional Genomics 2009: 1-8.

Buchan, J.R., Aucott, L.S., and Stansfield, I. (2006). tRNA properties help shape codon pair preferences in open reading frames. Nucleic Acids Research 34(3): 1015-1027.

Carraway, M.S., Suliman, H.B., Kliment, C., Weltywolf, K.E., Oury, T.D., and Piantadosi, C.A. (2008). Mitochondrial Biogenesis in the Pulmonary Vasculature During Inhalational Lung Injury and Fibrosis. Antioxtd Redox Signal. 10(2): 269-275.

Carroll, J., Fearnley, I.M., Skehel, J.M., Shannon, R.J., Hirst, J., and Walker, J.E. (2006). Bovine complex I is a complex of 45 different subunits. Journal of Biological Chemistry 281: 32724-32727.

Chabanon, H., Mickleburgh, I., and Hesketh, J. (2004). Zipcodes and postage stamps: mRNA localization signals and their trans-acting binding proteins. Briefings in Functional Genomics and Proteomics 3(3): 240-256.

Chaciñska, A., and Boguta, M. (2000). Coupling of mitochondrial translation with the formation of respiratory complexes in yeast mitochondria. Acta Biochimica Polonica 47(4): 973991.

Chang, K.J., and Wang, C.C. (2004). Translation initiation from a naturally occurring non-AUG codon in Saccharomyces cerevisiae. Journal of Biological Chemistry 279(14): 13778-85.

Chen, Z-Y., He, C-Y., Ehrhardt, A., Kay, M.A. (2003). Minicircle DNA vectors devoid of bacterial DNA result in persistent and high-level transgene expression in vivo. Molecular therapy. the journal of the American Society of Gene Therapy 8(3):495-500.

Choo, H.J., Kim, J.H., Kwon, O.B., Lee, C.S., Mun, J.Y., Han, S.S., Yoon, Y.S., Yoon, G., Choi, K.M. and Ko, Y.G. (2006). Mitochondria are impaired in the adipocytes of type 2 diabetic mice. Diabetologia 49: 784-791. 
Collombet, J-M., and Coutelle, C. (1998). Towards gene therapy of mitochondrial disorders. Molecular Medicine Today 4(1): 31-38.

Corral-Debrinski, M., Blugeon, C., and Jacq, C. (2000). In Yeast, the 3' Untranslated Region or the Presequence of $A T M 1$ Is Required for the Exclusive Localization of Its mRNA to the Vicinity of Mitochondria. Molecular and Cellular Biology 20(21): 7881-7892.

Daum, G. (2000). The Yeast Saccharomyces cerevisiae, a Eukaryotic Model for Cell Biology Microscopy Research and Technique 51: 493-495.

DiMauro, S., Bonilla, E., Davidson, M., Hirano, M., and Schon, E.A. (1998). Mitochondria in neuromuscular disorders. Biochimica et Biophysica Acta 1366: 199-210.

DiMauro, S., and Mancuso, M. (2007). Mitochondrial Diseases: Therapeutic Approaches. Bioscience Reports 27(1-3): 125-137.

Dragatsis, I., and Zeitlin, S. (2001). A method for the generation of conditional gene repair mutations in mice. Nucleic acids research 29(3): 1-9.

Du, H., and Yan, S.S.D. (2010). Mitochondrial medicine for neurodegenerative diseases. The Internatıonal Journal of Biochemistry \& Cell Biology 42: 560-572.

Dunstan, H.M., Green-Willms, N.S., and Fox, T.D. (1997). In Vivo analysis of Saccharomyces cerevisiae COX2 mRNA 5'-untranslated leader functions in mitochondrial translation initiation and translational activation. Genetics 147: 87-100.

Eliyahu, E., Pnueli, L., Melamed, D., Scherrer, T., Gerber, A.P., Pines, O., Rapaport, D., and Arava, Y. (2010). Tom20 Mediates Localization of mRNAs to Mitochondria in a Translation-Dependent Manner. American Society for Microbiology 30(1): 284-294.

Folley, L.S., and Fox, T.D. (1991). Site-directed mutagenesis of a Saccharomyces cerevisiae mitochondrial translation initiation codon. Genetics 129(3):659-668.

Foury, F., and Kucej, M. (2001). Yeast mitochondrial biogenesis: a model system for humans? Current Opinion in Chemical Biology 6: 106-111.

Fox, S.I. (2009). Fundamentals of Human Physiology, $1^{\text {st }}$ ed. McGraw-Hill, New York, U.S.A.

Fünfschilling, U., and Rospert, S. (1999). Nascent Polypeptide-associated Complex Stimulates Protein Import into Yeast Mitochondria. Molecular Biology of the Cell 10: 3289-3299.

Garcia, M., Darzacq, X., Delaveau, T., Jourdren, L., Singer, R. H., and Jacq, C. (2007). Mitochondria-associated Yeast mRNAs and the Biogenesis of Molecular Complexes. Molecular Biology of the Cell 18: 362-368. 
Garcia, M., Delaveau, T., Goussard, S., and Jacq, C. (2010). Mitochondrial presequence and open reading frame mediate asymmetric localization of messenger RNA. EMBO Reports 11(4): $285-291$.

Gasser, T. (2009). Molecular pathogenesis of Parkinson disease: insights from genetic studies. Expert Reviews in Molecular Medicine 11(e22): 1-20.

Goffeau, A., Barrell, B.G., Bussey, H., Davis, R.W., Dujon, B., Feldman, H., Galibert, F., Hoheisel, J.D., Jacq, C., Johnston, M., Louis, E.J., Mewes, H.W., Murakami, Y., Philippsen, P., Tettelin, H., and Oliver, S.G. (1996). Life with 6000 genes. Science 274: 546-567.

Gray, M.W., Burger, G., and Lang, B.F. (1999). Mitochondrial evolution. Science 283(5407): 1476-1481.

Green-Willms, N.S, Butler, C.A, Dunstan, H.M, and Fox, T.D. (2001). Pet111p, an inner membrane-bound translational activator that limits expression of the Saccharomyces cerevisiae mitochondrial gene COX2. Journal of Biological Chemistry 276(9): 63926397.

Green-Willms, N.S., Fox, T.D., and Costanzo, M.C. (1998). Functional interactions between yeast mitochondrial ribosomes and mRNA 5' untranslated leaders. Molecular and Cellular Biology 18(4): 1826-1834.

Griffiths, A.J.F., Miller, J.H., Suzuki, D.T., Lewontin, R.C., and Gelbart, W.M. (2000). An Introduction to Genetic Analysis, $7^{\text {th }}$ ed. W. H. Freeman and Company, New York, U.S.A.

Gualerzi, C. O., and Pon, C.L. (1990). Initiation of mRNA translation in prokaryotes. Biochemistry 29(25):5881-5889.

Horan, S., Bourges, I., Taanman, J.-W., and Meunier, B. (2005). Analysis of COX2 mutants reveals cytochrome oxidase subassemblies in yeast. Biochem. J. 390: 703-708.

Howell, N., Elson, J.L., Chinnery, P.F., and Turnbull, D.M. (2005). mtDNA mutations and common neurodegenerative disorders. Trends in Genetics 21(11): 583-586.

Hurowitz, E.H., and O Brown, P. (2003). Genome-wide analysis of mRNA lengths in Saccharomyces cerevisiae. Genome Biology 5(1): R2-R14.

Jansen, R.P. (2001). mRNA localization: message on the move. Nature Reviews - Molecular Cell Biology 2: 247-256.

Jensen, R.E., Aiken Hobbs, A.E., Cerveny, K.L., and Sesaki, H. (2000). Yeast mitochondrial dynamics: Fusion, Division, Segregation, and Shape. Microscopy Research and Technique 51: 573-583. 
Kagawa, Y., Inoki, Y., and Endo, H. (2001). Gene therapy by mitochondrial transfer. Advanced Drug and Delivery Reviews 49(1-2): 107-119.

Karbowski, M. (2010). Mitochondria on guard: role of mitochondrial fusion and fission in the regulation of apoptosis. Advances in Experimental Medicine and Biology 687:131-142.

Koene, S., and Smeitink, J. (2009). Mitochondrial medicine: entering the era of treatment. Journal of internal medicine 265(2):193-209.

Kortekaas, R., Leenders, K.L, van Oostrom, J.C.H., Vaalburg, W., Bart, J., Willemsen, A.T.M., and Hendrikse, N.H. (2005). Blood-brain barrier dysfunction in Parkinsonian midbrain in vivo. Annals of Neurology 57(2): 176-179.

Kozak, M. (1984). Point mutations close to the AUG initiator codon affect the efficiency of translation of rat preproinsulin in vivo. Nature 308: 241-246.

Kozak, M. (1989a). Circumstances and mechanisms of inhibition of translation by secondary structure in eucarytoic mRNAs. Molecular and Cellular Biology 9(11): 5134-5142.

Kozak, M. (1989b). The scanning model for translation: an update. The Journal of Cell Biology 108: $229-241$.

Kozak, M. (2005). Regulation of translation via mRNA structure in prokaryotes and eukaryotes. Gene 361: 13-37.

Kurland, C.G., and Andersson, S.G.E. (2000). Origin and Evolution of the Mitochondrial Proteome. Microblology and Molecular Biology Reviews 64(4): 786-820.

Laurence, J.M., Allen, R.D.M., McCaughan, G.W., Logan, G.J., Alexander, I.E., Bishop, G.A., and Sharland, A.F. (2009). Gene therapy in transplantation. Transplantation Reviews 23: 159-170.

Lazar, M.A. (2005). How obesity causes diabetes: not a tall tale. Science 307: 373-375.

Lemaire C., and Dujardin, G. (2008). Preparation of Respiratory Chain Complexes from Saccharomyces cerevisiae Wild-Type and Mutant Mitochondria - Activity Measurement and Subunit Composition Analysis. Methods in Molecular Biology 432: 65-81.

Lodish, H., Berk, A., Zipursky, S.L., Matsudaira, P., Baltimore, D., and Darnell, J.E. (2000). Molecular Cell Biology, $4^{\text {th }}$ ed. W.H. Freeman and company, New York, USA.

Lowell, B.B., and Shulman, G.I. (2005). Mitochondrial dysfunction and type 2 diabetes. Science (Washington) 307(5708): 384-387.

Loya, A., Pnueli, L., Yosefzon, Y., Wexler, Y., Ziv-Ukelson, M., and Arava, Y. (2008). The 3'UTR mediates the cellular localization of an mRNA encoding a short plasma membrane protein. $R N A$ 14: 1352-1365. 
Lu, B. (2009). Mitochondrial dynamics and neurodegeneration. Current neurology and neuroscience reports 9(3): 212-219.

Mager, W.H., and Winderickx, J. (2005). Yeast as a model for medical and medicinal research TRENDS in Pharmacological Sciences 26(5): 265-273.

Marc, P., Margeot, A., Devaux, F., Blugeon, C., Corral-Debrinski, M., and Jacq, C. (2002). Genome-wide analysis of mRNAs targeted to yeast mitochondria. European Molecular Biology Organization 3(2): 159-164.

Marella, M., Seo, B.B., Yagi, T., and Matsuno-Yagi, A. (2009). Parkinson's disease and mitochondrial complex I: a perspective on the Ndil therapy. Journal of bioenergetics and biomembranes 41(6): 493-497.

Margeot, A., Blugeon, C., Sylvestre, J., Jacq, C., and Corral-Debrinski, M. (2002). In Saccharomyces cerevisiae, ATP2 mRNA sorting to the vicinity of mitochondria is essential for respiratory function. European Molecular Biology Organization Journal 21: 6893-6904.

Margeot, A., Garcia, M., Wang, W., Tetaud, E., DiRago, J.P., and Jacq C. (2005). Why are many mRNAs translated to the vicinity of mitochondria: a role in protein complex assembly? Gene 354: 64-71.

Margulis, L. (1976). Genetic and evolutionary consequences of symbiosis. Experimental Parasitology 39(2):277-349.

Matsumoto, S., Takebe, I., and Machida, Y. (1988). Escherichta coli lacZ gene as a biochemical and histochemical marker in plant cells. Gene 66(1): 19-29.

Mazat, J.P., Fromentin, J., Heiske, M., Nazaret, C., and Ransac, S. (2010). Virtual mitochondrion: towards an integrated model of oxidative phosphorylation complexes and beyond. Biochemical Society Transactions 38(5):1215-1219.

McLachlan, J., Fernandez, S., Helleday, T., and Bryant, H.E. (2009). Specific targeted gene repair using single-stranded DNA oligonucleotides at an endogenous locus in mammalian cells uses homologous recombination. DNA repair 8(12):1424-1433.

Medeiros D.M. (2008). Assessing mitochondria biogenesis. Methods 46 (2008) 288-294.

Meisinger, C., Pfanner, N., and Truscott, K.N. (2006). Isolation of Yeast Mitochondria. Methods in Molecular Biology Yeast Protocols $2^{\text {nd }}$ ed 313: 33-39.

Mittelmeier, T.M., and Dieckmann, C.L. (1995). In Vivo Analysis of Sequences Required for Translation of Cytochrome $b$ Transcripts in Yeast Mitochondria. Molecluar and Cellular Biology 15(2): 780-789. 
Mori, K., Saito, R., Kikuchi, S., and Tomita, M. (2007). Inferring rules of Escherichia coli translational efficiency using an artificial neural network. Bio Systems 90(2): 414-420.

Mueller, C., and Flotte, T.R. (2008). Gene Therapy for Cystic Fibrosis. Clinical reviews in allergy \& immunology 35(3):164 -178.

Mulero, J.J., and Fox, T.D. (1993). PET111Acts in the 5'-Leader of the Saccharomyces cereuisiae Mitochondrial COX2 mRNA to Promote Its Translation. Genetics 133: 509516.

Mumberg, D., Müller, R., and Funk, M. (1994). Regulatable promoters of Saccharomyces cerevisiae: comparison of transcriptional activity and their use for heterologous expression. Nucleic Acids Research 22(25): 5767-5768.

Nakamoto, T. (2009). Evolution and the universality of the mechanism of initiation of protein synthesis. Gene 432(1-2): 1-6.

Nakamoto, T. (2010). Mechanisms of the initiation of protein synthesis: in reading frame binding of ribosomes to mRNA. Molecular Biology Reports 37: 1-9.

Navarro, A., and Boveris, A. (2010). Brain mitochondrial dysfunction in aging, neurodegeneration, and Parkinson's disease. Frontiers in Aging Neuroscience 2(34): 111.

Neupert, W. (1997). Protein import into mitochondria. Annual Review of Biochemistry 66: 863917.

Parikh, S. (2010). The neurologic manifestations of mitochondrial disease. Developmental Disabilities Research Review 16(2):120-128.

Park, J., Lee, G., and Chung, J. (2009). The PINK1-Parkin pathway is involved in the regulation of mitochondrial remodeling process. Biochemical and Biophysical Research Communications 378(3): 518-523.

Pelicano, H., Feng, L., Zhou, Y., Carew, J.S., Hileman, E.O, Plunkett, W., Keating, M.J., and Huang, P. (2003). Inhibition of mitochondrial respiration: A novel strategy to enhance drug-induced apoptosis in human leukemia cells by a reactive oxygen species-mediated mechanism. The Journal of Biological Chemistry 278(39): 37832-37839.

Petersen, K.F., Befroy, D., Dufour, S., Dziura, J., Ariyan, C., Rothman, D.L., DiPietro, L., Cline, G.W., and Shulman, G. (2003). Mitochondrial dysfunction in the elderly: possible role in insulin resistance. Science 300: 1140-1142.

Pradelli, L.A, Bénéteau, M., and Ricci, J-E. (2010). Mitochondrial control of caspase-dependent and -independent cell death. Cellular and molecular life sciences 67(10):1589-1597. 
Pulkes, T., and Hanna, M.G. (2001). Human mitochondrial DNA diseases. Advanced Drug Delivery Reviews 49(1-2): 27-43.

QIAprep Miniprep Handbook, $2^{\text {nd }}$ ed. (2006). Retrieved from http://www.qiagen.com/products/plasmid/qiaprepminiprepsystem/qiaprepspinminiprepkit .aspx

QIAquick Spin Handbook. (2008). Retrieved from http://www.qiagen.com/products/dnacleanup/pcrcleanup.aspx

Sack Jr., G.H. (2009). Mitochondrial matters in Parkinson disease: introduction. Journal of Bioenergetics and Biomembranes 41: 465-467.

Saint-Georges, Y., Garcia, M., Delaveau, T., Jourdren, L., Le Crom, S., Lemoine, S., Tanty, V., Devaux, F., and Jacq, C. (2008). Yeast mitochondrial biogenesis: a role for the PUF RNA-binding protein Puf3p in mRNA localization. PloS one 3(6): e2293-2304.

Saint-Georges, Y., Hamel, P., Lemaire, C., and Dujardin, G. (2001). Role of positively charged transmembrane segments in the insertion and assembly of mitochondrial inner-membrane proteins. Proceedings of the National Academy of Sciences of the USA 98(24): 13814 13819.

Sambrook, J., Fritsch, E.F., and Maniatis, T. (2000). Molecular Cloning - A Laboratory Manual, $2^{\text {nd }}$ ed. Cold Spring Harper Laboratory Press, Cold Spring Harbor, NY.

Schapira, A.H.V. (2010). Complex I: Inhibitors, inhibition and neurodegeneration. Experimental Neurology 224: 331-335.

Schulz, J.B., and Falkenburger, B.H. (2004). Neuronal pathology in Parkinson's disease. Cell and Tissue Research 318: 135-147.

Schwimmer, C., Rak, M., Lefebvre-Legendre, L., Duvezin-Caubet, S., Plane, G., and DiRago, J.P. (2006). Yeast models of human mitochondrial diseases: From molecular mechanisms to drug screening. Biotechnology Journal 1: 270-281.

Sickmann, A., Reinders, J., Wagner, Y., Joppich, C., Zahedi, R., Meyer, H.E., Schoenfisch, B., Perschil, I., Chacinska, A., Guirard, B., Rehling, P., Pfanner, N., and Meisinger, C. (2003). The proteome of Saccharomyces cerevisiae mitochondria. Proceedings of the National Academy of Sciences, USA 100(23): 13207-13212.

Smeitink, J., Van Den Heuvel, L., and DiMauro, S. (2001). The genetics and pathology of oxidative phosphorylation. Nature Reviews Genetics 2(5): 342-352.

Solomon, E.P., Berg, L.R., and Martin, D.W. (1999). Biology, $5^{\text {th }}$ ed. Harcourt College Publishers, Orlando, FL. 
Steinmetz, L.M., Scharfe, C., Deutschbauer, A.M., Mokranjac, D., Herman, Z.S., Jones, T., Chu, A.M., Giaever, G., Prokisch, H., Oefner, P.J., and Davis, R.W. (2002). Systematic screen for human disease genes in yeast. Nature Genetics 31: 400-404.

Stuart, J.A., and Brown, M.F. (2006). Mitochondrial DNA maintenance and bioenergetics. Biochimica et Biophysica Acta 1757: 79-89.

Sund, J., Andér, M., and Åqvist, J. (2010). Principles of stop-codon reading on the ribosome. Nature 465: 947-950.

Suter, B., Auerbach, D., and Stagljar, I. (2006). Yeast-based functional genomics and proteomics technologies: the first 15 years and beyond. BioTechniques 40: 625-644.

Sylvestre, J., Margeot, A., Jacq, C., Dujardin, G., and Corral-Debrinski, M. (2003a). The Role of the 3' untranslated region in mRNA sorting to the vicinity of mitochondria is conserved from yeast to human cells. Molecular Biology of the Cell 14(9): 3848-3856.

Sylvestre, J., Vialette, S., Corral-Debrinski, M., and Jacq, C. (2003b). Long mRNAs coding for yeast mitochondrial proteins of prokaryotic origin preferentially localize to the vicinity of mitochondria. Genome Biology 4(7): R44.1-44.9.

Szewczyk, A., and Wojtczak, L. (2002). Mitochondria as a Pharmacological Target. Pharmacol Rev 54: 101-127.

Tong, A.H.Y., Lesage, G., Bader, G.D., Ding, H., Xu, H., Xin, X., Young, J., Berriz, G.F., Brost, R.L., Chang, M., Chen, Y., Cheng, X., Chua, G., Friesen, H., Goldberg, D.S, Haynes, J., Humphries, C., He, G., Hussein, S., Ke, L., Krogan, N., Li, Z., Levinson, J.N., Lu, H., Ménard, P., Munyana, C., Parsons, A.B., Ryan, O., Tonikian, R., Roberts, T., Sdicu, AM., Shapiro, J., Sheikh, B., Suter, B., Wong, S.L., Zhang, L.V., Zhu, H., Burd, C.G., Munro, S., Sander, C., Rine, J., Greenblatt, J., Peter, M., Bretscher, A., Bell, G., Roth, F.P., Brown, G.W., Andrews, B., Bussey, H., and Boone, C. (2004). Global mapping of the yeast genetic interaction network. Science 303: 808-813.

Tuppen, H.A.L., Blakely, E.L., Turnbull, D.M., and Taylor, R.W. (2010). Mitochondrial DNA mutations and human disease. Biochimica et Biophysica Acta 1797: 113-128.

Valente, L., and Kinzy, T.G. (2003). Yeast as a sensor of factors affecting the accuracy of protein synthesis. Cellular and Molecular Life Sciences 60(10): 2115-2130.

Vega Laso, M.R., Zhu, D., Sagliocco, F., Brown, A.J.P., Tuite, M.F., and McCarthy, J.E.G. (1993). Inhibition of Translational Initiation in the Yeast Saccharomyces cerevisiae as a Function of the Stability and Position of Hairpin Structures in the mRNA Leader. The Journal of Biological Chemistry 268(9): 6453-6462.

Wallace, D.C. (2005). A mitochondrial paradiagm of metabolic and degenerative diseases, aging, and cancer: a dawn for evolutionary medicine. Annual review of genetics 39: 359-407. 
Wallace, D.C., and Fan, W. (2010). Energetics, epigenetics, mitochondrial genetics. Mitochondrion 10: 12-31.

Wang, C-H., Wang, C-C., and Wei, Y-H. (2010). Mitochondrial dysfunction in insulin insensitivity: implication of mitochondrial role in type 2 diabetes. Annals of the New York Academy of Sciences 1201:157-165.

Whitworth, A.J., and Pallanck, L.J. (2009). The PINK1/Parkin pathway: a mitochondrial quality control system? Journal of Bioenergetics and Biomembranes 41(6): 499-503.

Wickens, M., Bernstein, D.S., Kimble, J., and Parker, R. (2002) A PUF family portrait: 3'UTR regulation as a way of life. Trends in Genet 18: 150-157.

Wiedemann, N., Frazier, A.E., and Pfanner, N. (2004) The protein import machinery of mitochondria. Journal of Biological Chemistry 279: 14473-14476.

Winklhofer K.F., and Haass, C. (2010). Mitochondrial dysfunction in Parkinson's disease. Biochımica et Biophysıca Acta 1802(1): 29-44.

Yoritaka, A., Hattori, N., Uchida, K., Tanaka, M., Stadtman, E.R., and Mizuno, Y. (1996). Immunohistochemcial detection of 4-hydroxynonenal protein adducts in Parkinson disease. Proc Natl Acad Scl USA 93: 2696-2701.

Zischka, H., Weber, G., Weber, P.J., Posch, A., Braun, R.J., Bühringer, D., Schneider, U., Nissum, M., Meitinger, T., Ueffing, M., and Eckerskorn, C. (2003). Improved proteome analysis of Saccharomyces cerevisiae mitochondria by free-flow electrophoresis. Proteomics 3(6): 906-916. 